\title{
TEORES DE URÉIA EM DIETAS COM CANA-DE-AÇÚCAR: FERMENTAÇÃO RUMINAL E CONCENTRAÇÕES DE URÉIA PLASMÁTICA EM BOVINOS LEITEIROS
}

\author{
SORAIA VANESSA MATARAZZO
}

ZOOTECNISTA

Orientador: Prof. Dr. WILSON ROBERTO SOARES MATTOS

Dissertaçāo apresentada à Escola Superior de Agricultura "Luiz de Queiroz", Universidade de São Paulo, para obtenção do título de mestre em Agronomia, Área de Concentração: Ciência Animal e Pastagens.

PIRACICABA

Estado de São Paulo - Brasil

Março - 1999 
Dados Internacionais de Catalogação na Publicação (CIP)

DIVISÃO DE BIBLIOTECA E DOCUMENTAÇĀO - Campus "Luiz de Queiroz"/USP

\author{
Matarazzo, Soraia Vanessa \\ Teores de uréia em dietas com cana-de-açúcar: fermentação ruminal e concentraçōes \\ de uréia plasmática em bovinos leiteiros / Soraia Vanessa Matarazzo. - - Piracicaba, 1999. \\ $63 \mathrm{p}$. \\ Dissertação (mestrado) - - Escola Superior de Agricultura Luiz de Queiroz, 1999. \\ Bibliografia. \\ 1. Bovino leiteiro 2. Cana-de-açúcar 3. Dieta animal 4. Fermentação ruminal 5. \\ Produção animal 6. Teor 7. Uréia I. Título
}

CDD 636.214

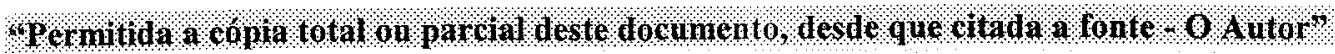




\section{À minha mãe, minha avó Amélia e meu irmão Anibal, por todo amor e respeito a minha opção de vida; Ofereço}

À memória de meu inesquecível e adorado pai,

Dedico

\section{"o \\ O que o homem imaginar. ele conseguirá realizar... \\ (L. da Vinci)}


À Deus, pela força luz e amparo em todos os momentos da minha vida...

Ao Prof. Dr. Wilson R. S. Mattos pelos ensinamentos, incentivo e sobretudo pela lição de vida;

À Maria Claudia A. Sucupira e Paulo Farano Stacchini pela dedicação, companheirismo e paciência;

Ao Prof. Dr. José Manuel Correia de Simas pela participação integral em todas as etapas do experimento;

Ao Prof. Dr. Alexandre Vaz Pires pelas cirurgias e concessão dos animais:

Ao amigo Carlos César Alves, técnico do Laboratório de Bromatologia, pela competência profissional e principalmente pela amizade;

Aos companheiros do CEPENA, Maria Teresa Guidi e Mário P. Menezes Jr. por "todos" os momentos compartilhados durante a fase experimental:

As queridas amigas Patrícia Paulleti e Michelle N. X. da Costa pelo carinho, apoio e "acolhimento":

A você Tum pelo carinho, atenção, paciência e principalmente, por fazer parte da minha vida....

À todos os colegas do curso de Ciência Animal e Pastagens pela convivência e experiências trocadas;

À ESALQ/USP pela oportunidade de realização do curso do PósGraduação:

À CAPES pela bolsa de estudo:

À FAPESP pelo suporte financeiro:

À querida FCAVJ/UNESP pela minha formação em Zootecnia;

Enfim, a todos que direta ou indiretamente me ajudaram a chegar até aqui, e, respeitosamente aos animais utilizados: Azeitona, Cachola, Madalena e Wirsa

Muito obrigada... 


\section{SUMÁRIO}

Página

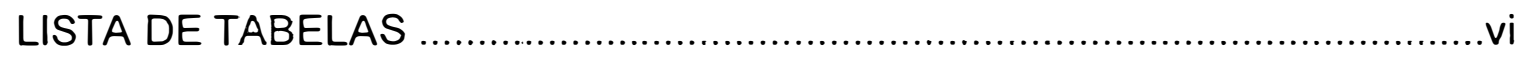

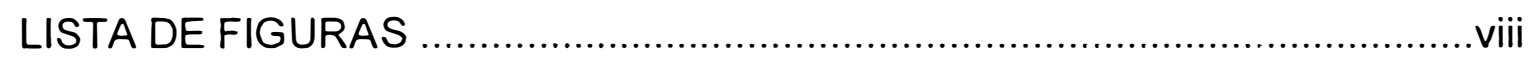

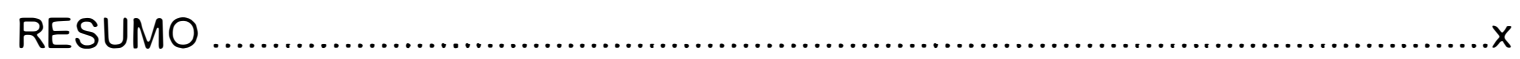

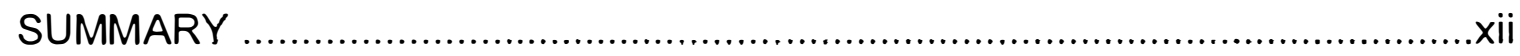

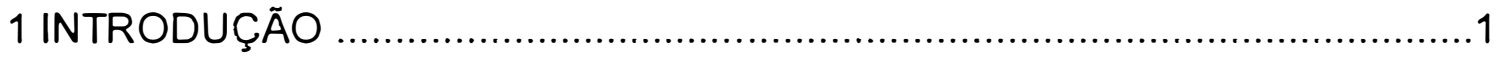

2 REVISÃO DE LITERATURA

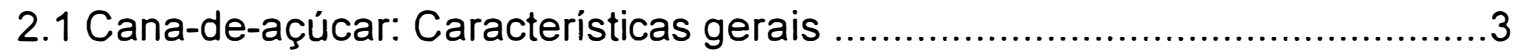

2.2 Aspectos nutricionais da cana-de-açúcar .............................................. 4

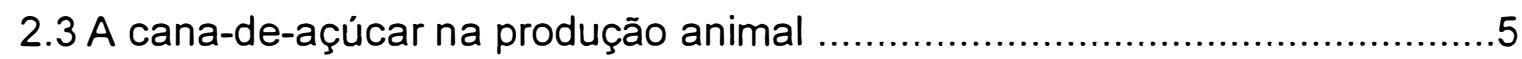

$2.4 \mathrm{pH}$

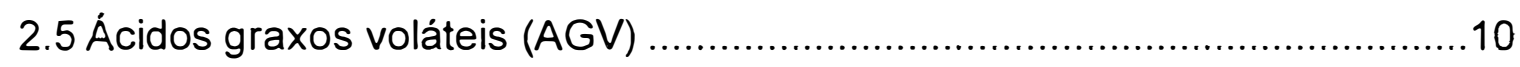

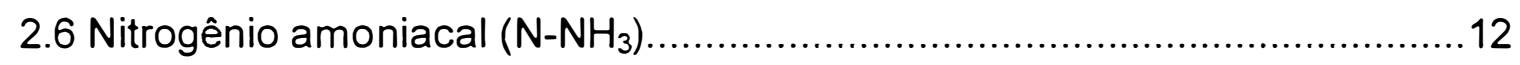

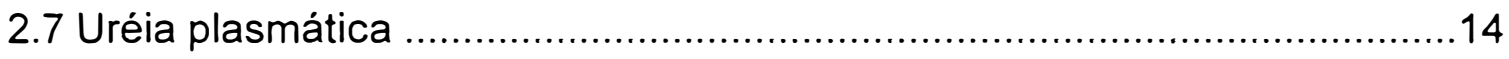

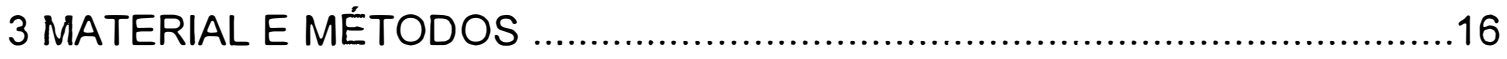

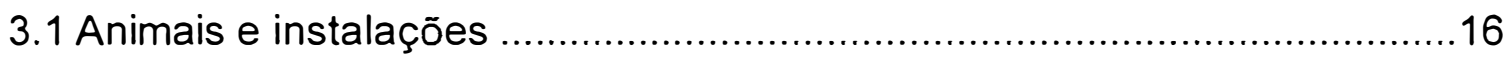

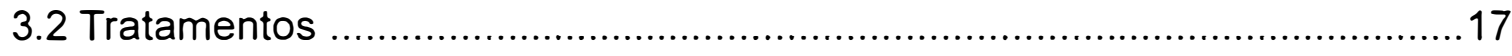

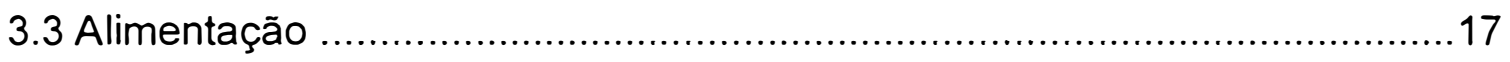

3.4 Delineamento experimental e análise estatística ...................................19

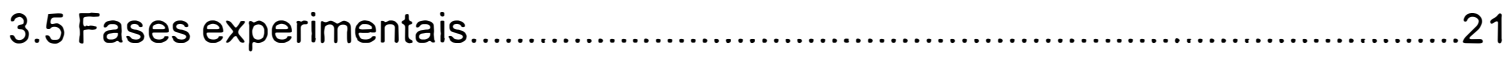

3.6 Amostragem dos dados referentes ao consumo de matéria seca...............21

3.7 Amostagem de fluido ruminal para determinação de $\mathrm{pH}, \mathrm{AGV}$ e N-NH $\mathrm{N}_{3} \ldots . .22$

3.8 Amostragem sanguínea para determinação da uréia plasmática ...............22

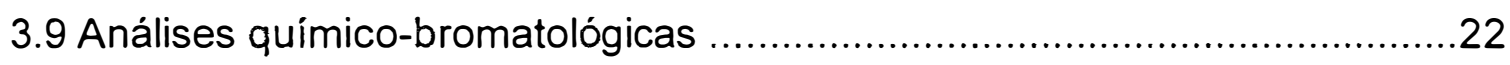

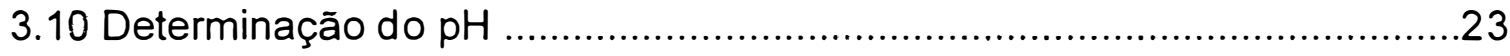

3.11 Determinação dos ácidos graxos voláteis (AGV) …................................23

3.12 Determinação do nitrogênio amoniacal (N-NH3) ....................................24 


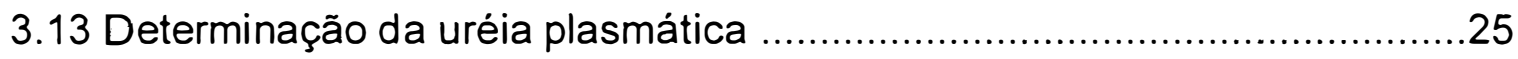

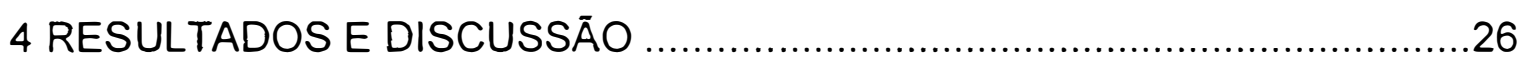

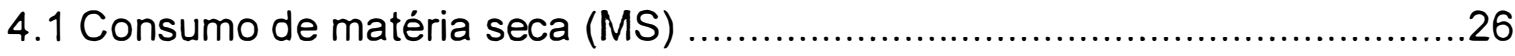

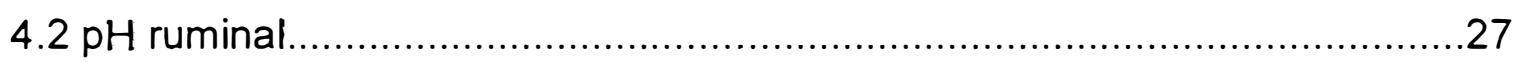

4.3 Concentração de ácidos graxos voláteis totais (AGVtotais) .......................32

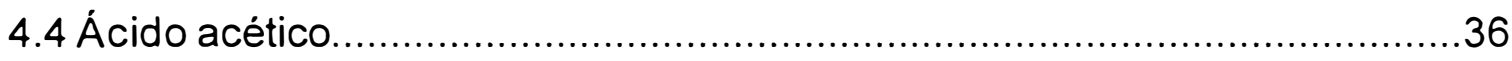

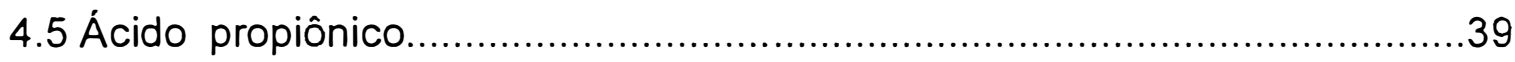

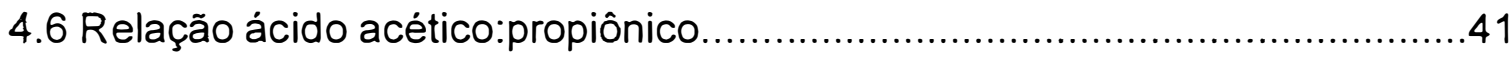

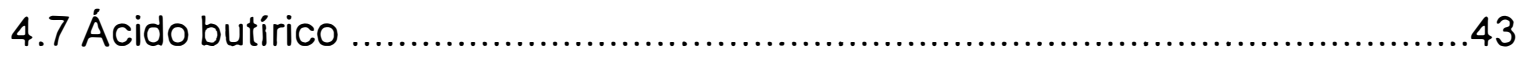

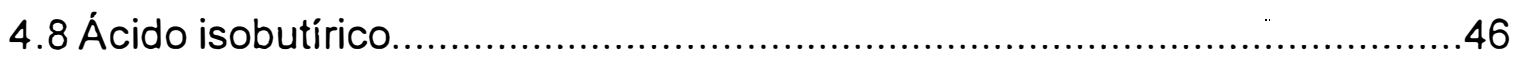

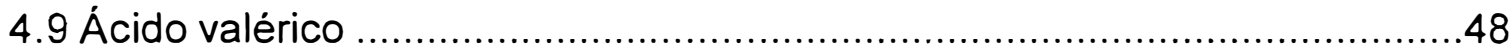

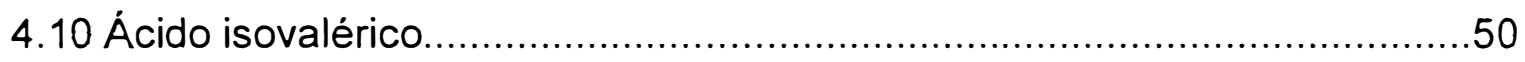

4.11 Concentração de nitrogênio amoniacal (N-NH3) …................................52

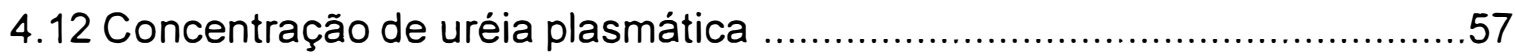

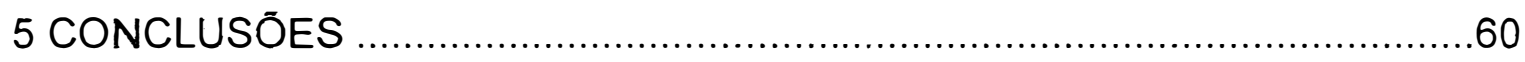

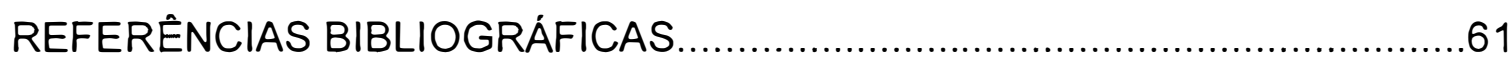




\section{LISTA DE TABELAS}

Página

1 Composição químico-bromatológica das dietas experimentais

2 Delineamento experimental em Quadrado Latino $4 \times 4$

3 Valores médios do consumo de MS $(\mathrm{kg})$ dos animais distribuídos nos tratamentos adotados

4 Valores médios do $\mathrm{pH}$ no fluido ruminal de acordo com as dietas experimentais e os tempos de amostragem.

5 Valores médios da concentração de AGV totais no fluido ruminal de acordo com as dietas experimentais e os tempos de amostragem.

6 Valores médios da porcentagem de ácido acético no fluido ruminal de acordo com as dietas experimentais e os tempos de amostragem

7 Valores médios da porcentagem de ácido propiônico no fluido ruminal de acordo com as dietas experimentais e os tempos de amostragem.

8 Valores médios da relação ácido acético:propiônico no fluido ruminal de acordo com as dietas experimentais e os tempos de amostragem

9 Valores médios da porcentagem de ácido butírico no fluido ruminal de acordo com as dietas experimentais e os tempos de amostragem

10 Valores médios da porcentagem de ácido isobutírico no fluido ruminal de acordo com as dietas experimentais e os tempos de amostragem 47 
11 Valores médios da porcentagem de ácido valérico no fluido ruminal de acordo com as dietas experimentais e os tempos de amostragem

12 Valores médios da porcentagem de ácido isovalérico no fluido ruminal de acordo com as dietas experimentais e os tempos de amostragem

13 Valores médios da concentração $\mathrm{N}-\mathrm{NH}_{3}$ no fluido ruminal de acordo com as dietas experimentais e os tempos de amostragem.

14 Valores médios da concentração de uréia plasmática de acordo com as dietas experimentais e os tempos de amostragem 


\section{LISTA DE FIGURAS}

Página

1 Equação de regressão ajustada em função dos tempos de amostragem para a dieta $\mathrm{A}$ 29

2 Equação de regressão ajustada em função dos tempos de amostragem para a dieta B. 29

3 Equação de regressão ajustada em função dos tempos de amostragem para todas as dietas. .30

4 Equação de regressão ajustada em função dos tempos de amostragem para todas as dietas.

5 Equação de regressão ajustada em função dos tempos de amostragem para todas as dietas.

6 Equação de regressão ajustada em função dos tempos de amostragem para todas as dietas.

7 Equação de regressão ajustada em função dos tempos de amostragem para todas as dietas.

8 Equação de regressão ajustada em função dos tempos de amostragem para todas as dietas. 38

9 Equação de regressão ajustada em função dos tempos de amostragem para todas as dietas. 
10 Equação de regressão ajustada em função dos tempos de amostragem para todas as dietas

11 Equação de regressão ajustada em função dos tempos de amostragem para todas as dietas.

12 Equação de regressão ajustada em função dos tempos de amostragem para todas as dietas

13 Equação de regressão ajustada em função dos tempos de amostragem para todas as dietas

14 Equação de regressão ajustada em função dos tempos de amostragem para todas as dietas.

15 Equação de regressão ajustada em função dos tempos de amostragem para todas as dietas.

16 Equação de regressão ajustada em função dos tempos de amostragem para a dieta C

17 Equação de regressão ajustada em função dos tempos de amostragem para a dieta D.

18 Equação de regressão ajustada em função dos tempos de amostragem para todas as dietas. 


\title{
TEORES DE URÉIA EM DIETAS COM CANA-DE-AÇÚCAR : FERMENTAÇÃO RUMINAL E CONCENTRAÇŌES DE URÉIA PLASMÁTICA EM BOVINOS LEITEIROS
}

\author{
Autora: SORAIA VANESSA MATARAZZO \\ Orientador: Prof. Dr. WILSON ROBERTO SOARES MATTOS
}

\section{RESUMO}

Foram utilizadas quatro vacas holandesas providas de cânula ruminal, em um delineamento Quadrado Latino $4 \times 4$ com o objetivo de avaliar a fermentação ruminal e as concentrações de uréia plasmática em dietas constituidas por cana-de-açúcar suplementada com farelo de soja e teores de uréia $(1,0 \% ; 1,5 \%$ e $2,0 \%$ na matéria original) respectivamente, tratamentos $A$, $B, C$ e $D$. O consumo de $M S$ foi maior $(P<0,05)$ para o tratamento $A$ em relação aos demais. Os valores de $\mathrm{pH}$ do fluido ruminal verificados entre os tempos de amostragem apresentaram efeito quadrático $(P<0,05)$ para os tratamentos $A$ e $B$ entre $0-10$ horas. Entre 12-22 horas foram observadas diferenças $(P<0,05)$ entre os tratamentos, sendo que $D$ foi superior ao $A$. Os resultados observados entre os tempos de amostragem revelaram efeito quadrático $(P<0,05)$ para todos os tratamentos. Para a concentração de AGV totais, porcentagem dos ácidos acético, propiônico, relação ácido acético:propiônico foram observados efeito quadrático $(P<0,05)$ para todos os tratamentos em ambos periodos $(0-10$ horas e 12-22 horas). A relação ácido acético:propiônico diferiu entre os tratamentos $(P<0,05)$ durante $12-22$ horas, no qual o tratamento $A$ apresentou maior relação que $C$. A porcentagem de ácido butírico apresentou efeito linear $(P<0,05)$ entre 12-22 horas. Para a porcentagem de ácido isobutírico verificouse efeito linear $(P<0,05)$ entre 0 -10 horas e efeito quadrático $(P<0,05)$ entre 1222 horas. A porcentagem de ácido isovalérico apresentou efeito quadrático $(P<0,05)$ entre $0-10$ horas. As maiores concentrações de $\mathrm{N}-\mathrm{NH}_{3}(P<0,05)$ foram 
constatadas para o tratamento $D$ comparado com $A$ e $B$ em ambos periodos. Entre $0-10$ horas observou-se efeito quadrático $(P<0,05)$ para os tratamentos $C$ e $D$; e entre 12-22 horas verificou-se efeito quadrático $(P<0,05)$ para todos os tratamentos. As concentrações de uréia plasmática foram influenciadas pelos tratamentos $(P<0,05)$. Durante $0-10$ horas os tratamentos $C$ e $D$ não diferiram entre si, porém, foram superiores ao $A$ e $B$. Entre 12-22 horas o tratamento $D$ foi superior ao $A$ e $B$. $O$ tratamento $C$ apresentou maior concentração de uréia plasmática quando comparado com $\mathrm{A}$. 


\title{
UREA SUPPLEMENTED SUGAR CANE DIETS: RUMEN FERMENTATION AND PLASMA UREA CONCENTRATIONS IN DAIRY COWS
}

\author{
Author: Soraia Vanessa Matarazzo \\ Adviser: Prof. Dr. Wilson Roberto Soares Mattos
}

\section{SUMMARY}

Four rumen cannulated cows were used in a $4 \times 4$ Latin Square design to study the pattern of rumen fermentation and plasma urea concentrations of sugar cane based diets supplemented with soybean meal (treatment $A$ ) and three levels of urea (1.0; 1,5 and $2.0 \%$, treatments $B, C$ and $D$, respectively). Dry matter intake was higher $(P<.05)$ for treatment $A$ as compared to the other three. Ruminal $\mathrm{pH}$ within each sampling time showed a quadratic effect $(P<.05)$ for treatments $A$ and $B$ between 0 and 10 hours post the morning feeding. Between 0 and 10 hours after the afternoon feeding the $\mathrm{pH}$ for treatment $\mathrm{D}$ was higher than treatment $A(P<.05)$. Total volatile fatty acids, acetic, propionic and butyric acid concentrations and the acetic:propionic acids ratio showed a quadratic effect $(P<.05)$ for all treatments. The butyric acid concentration had a linear effect $(P<.05)$ between 0 and 10 hours post the afternoon feeding. The iso-butyric acid showed a linear effect $(P<.05)$ between 0 and 10 hours and a quadratic effect $(P<.05)$ between 0 and 10 hours, respectively after the morning and afternoon feedings, whereas the iso-valeric acid showed a quadratic effect $(P<.05)$ between 0 and 10 hours after the morning feeding. Plasma urea concentration was higher for treatment $D(P<.05)$ as compared to treatments $A$ and $B$. There was a quadratic effect in all treatments between 0 and 10 hours after the afternoon feeding. Treatments $C$ and $D$ showed a higher plasma urea concentration $(P<.05)$ as compared to treatments $A$ and $B$ between 0 and 10 after the morning feeding. Between 0 and 10 hours after the afternoon feeding 
treatment $D$ had a higher plasma urea concentration $(P<.05)$ than treatments $A$ and $B$, whereas treatment $C$ showed a higher concentration $(P<.05)$ than treatment $A$. 


\section{INTRODUÇĀO}

A cana-de-açúcar tem se mostrado um dos principais recursos forrageiros na alimentação de bovinos leiteiros dada a sua elevada produtividade de matéria seca, baixo custo de produção, disponibilidade em épocas de escassez de forragem, além da manutenção do valor nutritivo por periodos relativamente prolongados.

Entretanto, sua composição bromatológica caracteriza-se por baixos teores de proteina, fósforo e fibra de qualidade nutricionalmente inferior. Essas deficiências devem ser corrigidas a fim de que se estabeleça uma fermentação ruminal estável, favorecendo a eficiência de crescimento microbiano e a maximização da digestibilidade da fibra.

Dada a fácil possibilidade de correção das limitações nutricionais desta forrageira, dificilmente a cana-de-açúcar picada "in natura", será substituída por outras formas de utilização, principalmente nas épocas mais secas do ano.

A grande proporção de carboidratos fermentáveis encontrada na matéria seca da cana-de-açúcar permite que o baixo teor protéico da forrageira seja facilmente corrigido através da utilização de fontes de nitrogênio prontamente disponiveis no rúmen, entre estas fontes, destaca-se a uréia em função de seu baixo custo.

Geralmente, a recomendação feita para a utilização de uréia em dietas com cana-de-açúcar, corresponde a $10 \mathrm{~g}$ de uréia para $1 \mathrm{~kg}$ de cana inteira picada. Entretanto, o teor adequado de suplementação com uréia no qual o animal responderá positivamente, ainda não está estabelecido. 
Desta forma, o presente experimento teve por objetivos avaliar a fermentação ruminal ( $\mathrm{pH}$, ácidos graxos voláteis e nitrogênio amoniacal) e as concentrações de uréia plasmática em bovinos leiteiros recebendo dietas com cana-de-açúcar e uréia $(0 ; 1,0 ; 1,5$ e 2,0\%). 


\section{REVISÃO DE LITERATURA}

\subsection{Cana-de-açúcar: Caracteristicas gerais}

A cana-de-açúcar foi introduzida no país no início da colonização, e desde então, vem sendo amplamente empregada como recurso forrageiro na maioria das propriedades produtoras de leite.

Com a intensificação dos estudos sobre sua utilização na alimentação de ruminantes, a cana-de-açúcar "in natura" tem merecido destaque principalmente pelo baixo custo de produção, fácil disponibilidade, além do elevado potencial de produção de matéria seca e energia por unidade de área, em um único corte (Boin, 1987).

$\mathrm{Na}$ década de 50, a produtividade agrícola média da cana-de-açúcar no Estado de São Paulo era de 50 ton.ha-1 (Carvalho \& Graça, 1976). Atualmente, atinge 80 a 120 ton. ha ${ }^{-1}$; o que equivale a uma produção de matéria seca de 20

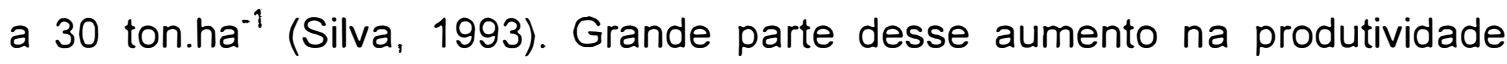
deve-se, sobretudo, às variedades melhoradas, as quais possuem resistência a pragas, doenças e ao chochamento (Matsuoka, 1991 e Nunes Jr., 1992).

Ao contrário das outras forrageiras tropicais que geralmente reduzem seu valor nutricional com o avançar da idade, o outro aspecto positivo da canade-açúcar refere-se a manutenção de seu valor nutritivo por períodos relativamente prolongados.

Segundo Pate (1977) tal fato deve-se a um incremento na concentração de sacarose simultânea a redução na concentração dos componentes da parede celular de baixa digestibilidade, decorrente da maturidade da planta. 
Assim, variações na concentração de sacarose relacionam-se diretamente com o valor nutritivo da cana-de-açúcar.

Os resultados encontrados por Boin (1985) apontaram correlação alta e positiva $(r=0,998)$ entre a digestibilidade da matéria seca e o teor de extrativo não nitrogenado, podendo inferir, então, que as variedades com conteúdo elevado de sacarose apresentam maiores valores de digestibilidade.

De forma semelhante, Matsuoka (1990) afirmou que uma variedade rica em sacarose implicaria em uma forrageira de melhor qualidade. Os mesmos autores concluiram ainda que grande parte das variedades industriais tem como época indicada para utilização o periodo mais seco do ano (junho a setembro).

\subsection{Aspectos nutricionais da cana-de-açúcar}

De acordo com Boin (1987) a composição bromatológica da cana-deaçúcar caracteriza-se por baixos teores de proteína bruta (1,8 e 4,7\%) e fósforo $(0,06$ e 0,08\%); além da baixa digestibilidade da fração fibrosa. Tais deficiências devem ser corrigidas para que se estabeleça uma fermentação ruminal estável, favorecendo a eficiência de crescimento microbiano e a maximização da digestibilidade da fibra (Leng, 1988).

Para Leng \& Preston (1976), a principal limitação da produtividade animal em dietas exclusivas com cana-de-açúcar deve-se ao baixo consumo de matéria seca, que por sua vez, restringe o fornecimento de aminoácidos para a sintese de proteinas e gluconeogênese e limita o suprimento de ácido propiônico para a sintese de glucose.

$\mathrm{Na}$ tentativa de melhorar a ingestão da forragem, foram conduzidos experimentos envolvendo formas de processamento da cana-de-açúcar (variações no tamanho de partícula, presença ou ausência de casca nos colmos) entretanto, nenhum dos processamentos apontaram diferenças para essas variáveis (Leng \& Preston, 1976). 
Montpellier \& Preston (1977) não verificaram diferenças no consumo voluntário que pudessem estar associadas aos métodos de processamento utilizados, porém, observaram um consumo duas vezes maior quando 0 processamento foi associado a suplementação protéica (polidura de arroz).

Um efeito positivo sobre a ingestão total de matéria seca pode ser encontrado com a inclusão da ponta da cana-de-açúcar nas dietas constituídas apenas por colmos descascados ou integrais. A provável causa desse efeito seria uma diferença no comportamento das frações fibrosas da ponta e do colmo da planta no rúmen (Boin, 1987).

Para Preston \& Leng (1981) o efeito das fontes de fibra longa nas dietas com cana-de-açúcar estariam relacionados com o aumento do volume ruminal e da taxa de fluxo da matéria seca, o que resultaria em maiores ingestões de forragem. As fibras longas estimulariam as contrações ruminais, aumentando as taxas de digestão e proporcionando um ambiente ruminal adequado aos microrganismos os quais aumentariam a disponibilidade de nutrientes para 0 hospedeiro.

\subsection{A cana-de-açúcar na produção animal}

Visando otimizar a utilização da cana-de-açúcar como alimento volumoso, é de fundamental importância optar por suplementos que corrijam adequadamente suas limitações nutricionais, bem como identificar a demanda de nutrientes essenciais a produção animal.

Dada a fácil possibilidade de correção das deficiências nutricionais desta forrageira, dificilmente a cana-de-açúcar picada "in natura", será substituida por outras formas de utilização, principalmente nas épocas mais secas do ano (Faria, 1993).

Em virtude da grande proporção de carboidratos fermentáveis na matéria seca, o baixo teor protéico da cana-de-açúcar pode ser facilmente corrigido com fontes de nitrogênio prontamente disponiveis no rúmen. 
Entre as fontes de nitrogênio não protéico (NNP) a uréia mostra-se uma das principais alternativas em função do baixo custo (Boin, 1987).

$\mathrm{Na}$ associação da cana-de-açúcar com a uréia, diversos trabalhos tem sugerido o uso de $10 \mathrm{~g}$ de uréia para $1 \mathrm{~kg}$ de cana-de-açúcar inteira picada, isto é, $1 \%$ de uréia na matéria original da forragem (Alvarez \& Preston, 1976; Ferreiro et al., 1977).

Para a incorporação desse composto de NNP tem sido recomendada uma solução aquosa de uréia (4 partes de água:1 parte de uréia). Tal maneira, além da praticidade, facilita a mistura da solução de uréia com a cana-deaçúcar picada, tendo a vantagem de proporcionar um consumo lento de NNP (Alvarez \& Preston, 1976).

Em dietas nas quais os teores de uréia são elevados faz-se necessária a presença de uma fonte de enxofre na dieta, a fim de atender as exigências dos microrganismos ruminais com relação a esse nutriente. Hunter \& Siebert (1980) afirmaram que a adição de nitrogênio e enxofre (N:S) nessas dietas seria benéfica pois além de corrigir a deficiência desses nutrientes, os quais são essenciais à síntese de proteina microbiana, também proporcionaria um maior consumo de energia resultante do aumento da digestibilidade da fração fibrosa.

O NRC (1988) recomendaram relações $\mathrm{N}: S$ de 12:1, sendo essas consideradas adequadas para atender as exigências dos microrganismos ruminais. No entanto, relações mais estreitas, poderiam em alguns casos, melhorar a utilização de nitrogênio, diminuindo as concentrações de $\mathrm{N}-\mathrm{NH}_{3}$ no rúmen e aumentando o nitrogênio retido.

Rodrigues (1992) verificou o efeito da suplementação com uréia e sulfato de cálcio em dietas com cana-de-açúcar sobre o consumo voluntário e ganho em peso de bovinos em crescimento, visando fornecer relações (N:S) 25:1, 13:1 e 9:1. Os dados obtidos mostraram aumentos no consumo de matéria seca $(5,10 \mathrm{~kg} ; 5,61 \mathrm{~kg}$ e $5,82 \mathrm{~kg}$; respectivamente para as relações supracitadas); porém o ganho em peso não foi alterado significativamente. 
Os resultados obtidos por Moreira (1986) revelaram que o fornecimento exclusivo de cana-de-açúcar adicionada de 1\% de uréia:sulfato de amônio, seria suficiente apenas para atender as necessidades de mantença dos animais. Tal conclusão foi obtida através do estudo de diferentes teores de inclusão $(0,5 \mathrm{~kg} ; 1,0 \mathrm{~kg} \mathrm{e} 1,5 \mathrm{~kg})$ de farelo de arroz nessas mesmas dietas.

Leng \& Preston (1976) utilizaram uma fonte protéica de baixa digestibilidade ruminal (polidura de arroz) associada a dieta com cana-deaçúcar, e comprovaram que tal suplemento estimulava o consumo voluntário e, consequentemente, o ganho em peso e a conversão alimentar.

Especificamente para bovinos leiteiros com altas produções, existe uma demanda elevada de determinados nutrientes, existindo então, a necessidade de suplementação com alimentos ricos em proteina sobrepassante, bem como ácidos graxos de cadeia longa e amido de baixa digestibilidade ruminal (Preston \& Leng, 1981).

Assim, o teor máximo de suplementação com NNP no qual o animal responderá positivamente, ainda é bastante discutivel; podendo em alguns casos estar associado a quantidade de proteina digestivel e não digestivel da dieta.

Rodrigues (1985) utilizou teores de uréia $(0,5 \% ; 1,0 \%$ e $1,5 \%$ na matéria original) em dietas com cana-de-açúcar para novilhas leiteiras em confinamento. Os resultados obtidos não demostraram diferenças no consumo de matéria seca, embora houvesse uma tendência das maiores ingestões estarem relacionadas aos teores mais elevados de uréia.

Satter \& Roffler (1975) sugeriram que o NNP é contra-indicado quando a exigência em proteina bruta é superior a $11-12 \%$. Porém, vários experimentos sumarizados por Huber (1984) mostraram que a produção de leite das vacas em início de lactação alimentadas com ração que continham uréia (15 - 17\% PB) ou fonte de proteina natural (15 - 17\% PB) não diferiram entre si; e ambas foram superiores ao controle (12 - 13\% PB). 
Wohlt \& Clark (1978) verificaram o efeito de dois concentrados isoprotéicos $(14,5 \% \mathrm{~PB})$ adicionados ou não de $1,5 \%$ de uréia sobre a produção de leite de vacas em início de lactação. Os animais que receberam o concentrado com $1,5 \%$ de uréia apresentaram produção de leite inferior; entretanto, o consumo de energia desses animais foi menor, podendo justificar em parte o decréscimo na produção.

As dietas que contém uréia muitas vezes resultam em decréscimo no consumo, mesmo em animais fisiologicamente adaptados a tolerar maiores quantidades de uréia. Esse decréscimo tem sido associado ao sabor amargo da uréia e não aos eventos ruminais e pós-ruminais (Huber, 1984).

Entretanto, Wilson et al. (1975) avaliaram o fornecimento de dois teores de uréia (1\% e $3 \%$ ) através de duas formas de administração (oral e via cânula ruminal). As dietas $A$ e $B(1 \%$ e $3 \%$ de uréia, respectivamente) foram oferecidas oralmente; na dieta $\mathrm{C}, 1 \%$ de uréia era fornecido oralmente e mais $2 \%$ eram infundidos na cânula ruminal; na dieta $D$ ( $3 \%$ de uréia) a infusão era contínua na cânula ruminal. Nesse experimento, as dietas com mais de $1 \%$ de uréia apresentaram menores ingestões de matéria seca, independente da forma de administração; indicando então, que o sabor da uréia não foi a única causa do decréscimo no consumo.

$O$ consumo de grandes quantidades de uréia (acima de 45 a $50 \mathrm{~g} \cdot \mathrm{kg}^{-1}$ de peso) por um curto periodo de tempo pode ser fatal ao animal não adaptado (Bartley et al., 1976); porém animais adaptados toleram duas a três vezes esta quantidade .

O mecanismo inicial no qual a adaptação ao NNP ocorre é através do aumento da sintese de uréia pelo fígado, minimizando a toxicidade de amônia pelos tecidos e facilitando a reciclagem de uréia pelo rúmen. Uma maneira simples de adaptar os animais a uréia é fracionar as quantidades de NNP de modo a fornecer $1 / 3$ da quantidade total durante a primeira semana, 2/3 na segunda e a quantidade total na terceira semana (Huber, 1984). 


\section{$2.4 \mathrm{pH}$}

As variações no $\mathrm{pH}$ do fluido ruminal ocorrem em função da composição da dieta, tamanho de partícula do alimento, velocidade de passagem da digesta e produção de saliva. Essas alterações, por sua vez, afetarão os produtos finais de fermentação, bem como a taxa de crescimento dos microrganismos e a espécie predominante (Church, 1988).

$\mathrm{O} \mathrm{pH}$ pode atingir valores de 5,5 a 6,2 em uma dieta rica em concentrado, enquanto que dietas constituidas por volumosos, geralmente apresentam $\mathrm{pH}$ entre 6,5 a 7,0 e resultam em aumento de microrganismos celulolíticos (Owens \& Goetsch,1988).

Segundo Owens \& Goetsch (1988), o intervalo de tempo compreendido entre meia e quatro horas após a alimentação é caracterizado por uma diminuição do $\mathrm{pH}$, refletindo o balanço entre a taxa de produção de ácidos graxos voláteis, ação tamponante da saliva elou a liberação de bases presentes nos alimentos.

Em dietas com cana-de-açúcar, o pH situa-se entre 6,8 a 7,3 mantendo valores altos e constantes, provavelmente devido a secreção salivar, onde grande parte do tempo é despendido com a mastigação e ruminação; e, não necessariamente em função das grandes quantidades de NNP incorporada as dietas; uma vez que animais privados de uréia ou alimentados com quantidades restritas desta, apresentaram valores de $\mathrm{pH}$ igualmente altos (Preston \& Leng, 1981).

Ravelo \& Leng (1976) conduziram um experimento a fim de avaliar a fermentação ruminal de bovinos alimentados com cana-de-açúcar e $1 \mathrm{~kg}$ de polidura de arroz suplementada ou não com $50 \mathrm{~g}$ de uréia por $\mathrm{kg}$ de cana fresca. Os resultados obtidos não denotaram diferenças entre os tratamentos para o pH; sendo encontrado valores de 6,85 (sem uréia) e 6,97 (com uréia).

Losada et al. (1979) avaliaram a adição de teores de uréia $(0 ; 7 ; 14$ ou $21 \%$ ) a uma solução de melaço como forma de suplementação de uma dieta 
com cana-de-açúcar. $\mathrm{O}$ pH apresentou um efeito quadrático com o aumento do teor de uréia na solução de melaço.

Manzano et al. (1983) avaliaram teores de farelo de soja $(0,3 ; 0,6 ; 0,9$ e $1,2 \mathrm{~kg}$ ) em dietas constituidas por cana-de-açúcar e não observaram diferenças nos valores de $\mathrm{pH}$ entre os tratamentos nos diferentes tempos de amostragem que pudessem ser atribuídas ao efeito da suplementação.

Aroeira et al. (1995) determinaram o valor do $\mathrm{pH}$ do fluido ruminal de bovinos alimentados com cana-de-açúcar e $1 \%$ de uréia adicionada de $22,5 \%$ de farelo de algodão. $\mathrm{O}$ pH ruminal permaneceu estável entre 5,6 e 6,6 durante todo o período de amostragem.

\section{5 Ácidos graxos voláteis (AGV)}

A fermentação dos alimentos pelos microrganismos ruminais, além de liberar energia e compostos nitrogenados para seu próprio crescimento, produz também ácidos graxos voláteis (AGV) os quais são a principal fonte de energia para o animal hospedeiro. Segundo Owens \& Goetsch (1988), em uma dieta com forragem, 50 a $85 \%$ da energia metabolizável utilizada pelo hospedeiro é proveniente da fermentação ruminal.

As concentrações de AGV são bastante variáveis, entretanto a quantidade total geralmente apresenta valores entre 60 e $150 \mathrm{mM}$. Excepcionalmente, podem ocorrer valores próximos a $200 \mathrm{mM}$; é o caso de dietas ricas em amido ou de animais submetidos a pastejo de forragens jovens. A concentração máxima de AGV no rúmen é atingida duas a quatro horas após a alimentação (Owens \& Goetsch,1988).

A quantidade de $A G V$ no fluido ruminal é o reflexo da atividade microbiana e da taxa de absorção destes pela mucosa ruminal. A sua proporção varia com o tipo de substrato, nivel de ingestão, freqüência de alimentação, taxa de diluição e osmolaridade (Church, 1988). 
O ácido acético predomina na maioria das condições; mas quantidades substanciais de ácido propiônico e butírico estão sempre presentes. Os ácidos isobutírico, valérico, isovalérico, 2-metilbutirico, hexanóico e heptanóico constituem menos de $5 \%$ do total (Bergman, 1990).

Para Preston \& Leng (1981) o padrão de fermentação ruminal das dietas com cana-de-açúcar ocupa uma posição intermediária entre os fenos de forragem de climas temperados e os concentrados. Os valores encontrados para AGV totais são geralmente altos (120-150 mM.L-1 $)$. Essas dietas apresentam maiores proporções de ácido propiônico (25 - 35\% do total); e menores de ácido butírico (10 - $25 \%$ do total).

Valdez et al. (1977) utilizaram uma dieta composta por cana-de-açúcar enriquecida com solução de melaço e uréia suplementada ou não com $1 \mathrm{~kg}$ de polidura de arroz. O pico de produção de AGV totais foi alcançado entre uma e duas horas após a alimentação; acompanhado de um gradual declínio nas horas subsequentes. Não foram observadas diferenças em função da suplementação com polidura de arroz. Os valores médios de AGV totais encontrados variaram entre 75 e $115 \mathrm{mM} . \mathrm{L}^{-1}$ de fluido ruminal. Também foram observados decréscimo na proporção de ácido acético e aumento na proporção de ácido propiônico após a alimentação.

Aroeira et al. (1993) utilizaram uma dieta composta por $85 \%$ da matéria seca proveniente de cana-de-açúcar incorporada com 1\% de uréia (na matéria original) suplementada com $15 \%$ de farelo de arroz ou de algodão. Não foram observadas diferenças nas concentrações de AGV em relação aos tratamentos; porém foram constatadas diferenças em relação aos diferentes tempos de amostragem.

Valvasori et al. (1998) avaliaram as alterações na fermentação ruminal de bovinos alimentados com cana-de-açúcar em substituição a silagem de milho $(0 ; 1 / 3 ; 2 / 3$ e 1$)$ e encontraram para a dieta exclusiva com cana-de-

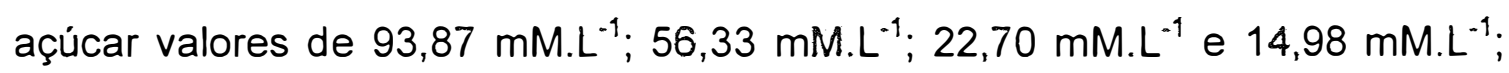
respectivamente para AGV totais, ácido acético, propiônico e butírico. 


\subsection{Nitrogênio amoniacal ( $\left.\mathrm{N}-\mathrm{NH}_{3}\right)$}

Os mecanismos fisiológicos básicos responsáveis pelo suprimento de $\mathrm{N}$ $\mathrm{NH}_{3}$ no rúmen consistem na degradação de proteínas, hidrólise do NNP dietético, hidrólise da uréia reciclada ao rúmen e degradação das células microbianas (Owens \& Zinn, 1988).

A maioria das bactérias ruminais utilizam $\mathrm{N}^{-\mathrm{NH}_{3}}$ como fonte de nitrogênio; embora algumas espécies necessitam de compostos nitrogenados adicionais (proteinas intactas ou cadeias carbônicas de certos aminoácidos).

Entretanto, para que o processo da sintese de proteina microbiana ocorra de maneira eficiente, torna-se necessária a presença de uma fonte adequada de energia no meio, uma vez que a energia fermentável influencia o crescimento dos microrganismos ruminais e a quantidade de $\mathrm{N}-\mathrm{NH}_{3}$ a ser convertida em proteina microbiana (Shirley, 1986).

A concentração ótima de $\mathrm{N}-\mathrm{NH}_{3}$ no fluido ruminal é aquela que resulta em máximas taxas de fermentação ou a que permita uma máxima produção de proteina microbiana por unidade de substrato fermentado; sendo essa concentração segundo Mehrez et al. (1977) o equivalente a $23,5 \mathrm{mg}^{-\mathrm{dl}^{-1}}$ de fluido ruminal.

Segundo Erdman et al. (1986) seria necessário um teor de $\mathrm{N}-\mathrm{NH}_{3}$ de 5 $\mathrm{mg} \mathrm{dl}^{-1}$ de fluido ruminal para que a incorporação de nitrogênio pelas bactérias fosse efetuado sem gasto de energia, e que este teor favoreceria principalmente as espécies celulolíticas, aumentando assim, a degradação das fibras.

Por outro lado, Satter e Slyter (1974), demonstraram "in vitro" que a concentração de $\mathrm{N}_{-} \mathrm{NH}_{3}$ de $5 \mathrm{mg} \mathrm{dl}^{-1}$ de fluido ruminal foi adequada para suportar uma máxima produção microbiana.

Em dietas com cana-de-açúcar sem suplementação protéica, as concentrações de $\mathrm{N}_{-} \mathrm{NH}_{3}$ no rúmen, encontram-se entre 1,0 a $4,0{\mathrm{mg} . d l^{-1}}^{-1}$ 
(Preston \& Leng, 1976), valor abaixo do mínimo 5,0 mg.dl ${ }^{-1}$ necessário para o máximo crescimento microbiano, segundo preconizou Satter e Slyter (1974).

Segundo Davidovich et al. (1977) dada a variação na concentração de $\mathrm{N}-\mathrm{NH}_{3}$ ruminal ocorrida ao longo das 24 horas, poderiam ocorrer periodos durante os quais a deficiência de $\mathrm{N}-\mathrm{NH}_{3}$ limitaria o crescimento microbiano.

Entretanto, a cana-de-açúcar suplementada com 3\% da matéria seca como uréia apresentou concentrações de $\mathrm{N}-\mathrm{NH}_{3}$ ruminal considerados adequados para máxima síntese de proteína microbiana.

Sniffen \& Robinson (1987) verificaram que em dietas nas quais a uréia foi a principal fonte de nitrogênio, os teores necessários de $\mathrm{N}-\mathrm{NH}_{3}$ para a máxima produção bacteriana foram 10 a $15 \mathrm{mg} \mathrm{dl}^{-1}$, e que dietas com outras fontes de proteína os valores estariam próximos de $8 \mathrm{mg}^{-\mathrm{dl}^{-1}}$.

Manzano et al. (1983) avaliaram teores de farelo de soja $(0,3 ; 0,6 ; 0,9$ e $1,2 \mathrm{~kg}$ ) em dietas constituídas por cana-de-açúcar e não observaram diferenças nos valores de $\mathrm{N}-\mathrm{NH}_{3}$ que pudessem ser atribuídas ao efeito da suplementação.

O experimento conduzido por Losada et al. (1979) verificou a suplementação da cana-de-açúcar através da adição de teores de uréia $(0 ; 7$; 14 ou $21 \%$ ) a uma solução de melaço. Os valores encontrados para a concentração de $\mathrm{N}-\mathrm{NH}_{3}$ no rúmen, aumentaram a medida que se elevaram os teores de uréia na solução de melaço.

O efeito dos teores de uréia $(1,0 ; 1,5$ e 2,0\%) sobre a fermentação ruminal também foi verificado por Rodriguez et al. (1993). As dietas eram compostas por $15 \%$ de farelo de algodão e $85 \%$ de cana-de-açúcar suplementada com os respectivos tratamentos. As concentrações médias de $\mathrm{N}$ $\mathrm{NH}_{3}$ foram elevadas e diferiram entre os tratamentos em função da suplementação com uréia.

Aroeira et al. (1995) avaliaram as concentrações ruminais de $\mathrm{N}-\mathrm{NH}_{3}$ proporcionadas por uma dieta com cana-de-açúcar adicionada de $1 \%$ de uréia 
e suplementada com farelo de algodão. Os valores encontrados variaram entre 10,0 e $27,9 \mathrm{mg}^{-\mathrm{dl}^{-1}}$.

\subsection{Uréia plasmática}

A uréia é formada pelo figado a partir da $\mathrm{N}-\mathrm{NH}_{3}$ a qual é produzida durante 0 catabolismo das proteinas. $O$ organismo gasta energia considerável para produzir a uréia a fim de evitar a toxicidade por $\mathrm{N}-\mathrm{NH}_{3}$ (Swenson \& Reece, 1996).

O excesso de proteina no rúmen associado a deficiência de energia eleva a produção de $\mathrm{N}-\mathrm{NH}_{3}$, aumentando então, a uréia no sistema. Assim, a concentração de uréia no sangue, soro, plasma ou leite está relacionada com a ingestão de proteina bruta, digestibilidade ou não da proteina dietética ou com a disponibilidade de carboidratos fermentáveis no rúmen (Moore \& Varga, 1996).

As concentrações de uréia sangüinea tem sido utilizada para monitorar o consumo de proteina dietética próximo às exigências do animal; uma vez que o consumo excessivo de proteina pode afetar e desempenho reprodutivo do animal, aumentar sua exigência em energia ou ainda, aumentar o custo da ração (Broderick \& Clayton, 1997).

Manzano et al. (1983) não encontraram diferenças para as concentrações de uréia plasmática entre os tratamentos $(0,3 ; 0,6 ; 0,9$ e 1,2 kg de farelo de soja), entretanto, houve uma tendência para maiores concentrações de uréia plasmática em função do aumento do teor protéico da dieta.

Miranda et al. (1998) determinaram os teores de uréia plasmática em novilhas alimentadas "ad libitum" com rações contendo 13\% de PB, em que $50 \%$ da proteina foi oriunda de proteina verdadeira e 50\% de NNP (uréia e cama de frango). As fontes de NNP foram testadas em relação a três fontes de 
probiótico (sem, com levedura ou com flora ruminal liofilizada). As médias das concentrações plasmáticas de uréia não diferiram entre os tratamentos. 


\section{MATERIAL E MÉTODOS}

Este experimento foi conduzido nas instalações pertencentes ao Departamento de Produção Animal da Escola Superior de Agricultura "Luiz de Queiroz" (ESALQ/USP), em Piracicaba, no periodo de outubro a dezembro de 1997.

\subsection{Animais e instalações}

Foram utilizadas quatro vacas Holandesas, multiparas, não lactantes, fistuladas no rúmen, com peso médio de $600 \mathrm{~kg}$. Os animais apresentavam bom estado sanitário tendo recebido tratamento profilático de rotina (controle de endo e ecto parasitas).

A cirurgia para a colocação das cânulas de rúmen foi realizada em agosto de modo a garantir a recuperação dos animais antes do início do periodo experimental. A cânula ruminal de material plástico (PVC), foi colocada na fossa paralombar esquerda, região correspondente ao saco posterior do rúmen.

Os animais permaneceram alojados em baias individuais cobertas, com piso de borracha, equipadas com bebedouro automático e cocho móveis durante todo período experimental.

As pesagens dos animais foram feitas em instalações próprias, anexa ao galpão, antes do início de cada sub-período experimental, utilizando-se balança com capacidade para $1500 \mathrm{~kg}$ e sensibilidade de $200 \mathrm{~g}$. 


\subsection{Tratamentos}

Os animais foram distribuidos nas seguintes dietas experimentais:

- $A=$ cana-de-açúcar + farelo de soja

- $B=$ cana-de-açúcar $+1,0 \%$ de uréia

- $C=$ cana-de-açúcar $+1,5 \%$ de uréia

- $\mathrm{D}=$ cana-de-açúcar $+2,0 \%$ de uréia

As dietas não eram isoprotéicas; sendo que $B, C$ e $D$ consistiam da mistura de uréia com sulfato de amônio na proporção de 9:1 (9,0 g de uréia : 1,0 g de sulfato de amônio por kg de cana-de-açúcar fresca); já a quantidade de farelo de soja fornecida (dieta A) estava associada ao teor protéico da dieta B. A Tabela 1 relaciona os ingredientes das dietas experimentais.

Tabela 1. Composição químico-bromatológica das dietas experimentais

\begin{tabular}{lrrrr}
\hline \multicolumn{5}{c}{ Dietas experimentais } \\
\hline & \multicolumn{1}{c}{ A } & \multicolumn{1}{c}{ B } & \multicolumn{1}{c}{ C } & \multicolumn{1}{c}{ D } \\
\hline MS & 31,79 & 27,18 & 26,94 & 26,44 \\
MO & 96,70 & 97,43 & 97,47 & 97,38 \\
MM & 3,30 & 2,58 & 2,63 & 2,62 \\
PB & 11,62 & 11,42 & 15,95 & 19,82 \\
FDN & 42,97 & 47,58 & 46,17 & 46,33 \\
FDA & 27,95 & 31,41 & 30,33 & 30,18 \\
& & & & \\
\hline
\end{tabular}

\subsection{Alimentação}

A cana-de-açúcar era cortada em dias alternados e estocada em local coberto. Diariamente foi feita a análise de sua qualidade, através da leitura do grau Brix em um refratômetro manual de campo (Toko ${ }^{\circledR}$, com escala de 0 $32 \%$ e sensibilidade de 0,2 ). 
No momento da alimentação, a cana-de-açúcar era então despalhada e passada com as pontas em um desintegrador de forragens. Uma vez homogeneizada, a quantidade de cana-de-açúcar fornecida ao animal era pesada em balança com precisão de $20 \mathrm{~g}$ e colocada no respectivo cocho.

A mistura uréia:sulfato de amônio correspondente a cada dieta ( $B, C$ e D) era pesada em balança com precisão de $0,01 \mathrm{~g}$ e dissolvida em água na proporção 4:1 (água:mistura). Posteriormente, esta solução era transferida para um regador e adicionada de maneira homogenea à cana-de-açúcar já no cocho.

A dieta $A$ apresentava teor protéico equivalente a $B$, de modo que a quantidade de farelo de soja fornecida, foi calculada considerando a porcentagem de matéria seca (MS) e a ingestão de cana-de-açúcar e os teores de proteina bruta (PB) da cana-de-açúcar e do farelo de soja. A quantidade determinada foi pesada em balança com precisão de $50 \mathrm{~g}$ e, em seguida, acrescentada à cana-de-açúcar da mesma maneira que os demais tratamentos.

Os animais receberam suplementação mineral na forma de "top dress" (cobertura), sendo adicionados $100 \mathrm{~g}$ de suplemento por refeição logo após a homogeneização das dietas nos cochos. Os teores de garantia para os elementos em cada $\mathrm{kg}$ do produto comercial eram os seguintes: fósforo (73 g), cálcio (130 g), magnésio (15 g), enxofre $(25 \mathrm{~g})$, sódio (156 g), cloro (249 g), zinco $(5.000 \mathrm{mg})$, cobre $(1.500 \mathrm{mg})$, ferro $(2.500 \mathrm{mg})$, manganês $(1.000 \mathrm{mg})$, cobalto (120 mg), iodo (180 mg), selênio ( $30 \mathrm{mg}$ ), flúor (máximo de $730 \mathrm{mg}$ ).

A alimentação era fornecida duas vezes ao dia (8h e $20 \mathrm{~h})$ e as quantidades de alimento oferecido e das sobras, bem como a qualidade da cana (grau Brix), foram registrados diariamente. O consumo de água foi "ad libitum". 


\subsection{Delineamento experimental e análise estatística}

O delineamento experimental adotado foi o Quadrado Latino $4 \times 4 \mathrm{em}$ esquema de parcelas subdivididas (split-plot), balanceado para efeito residual, constituido por quatro animais, quatro dietas experimentais e quatro periodos. A parcela foi constituida das dietas experimentais e as subparcelas dos tempos de amostragem. A Tabela 2 apresenta o delineamento experimental utilizado.

Tabela 2. Delineamento experimental em Quadrado Latino $4 \times 4$

\begin{tabular}{ccccc}
\hline \multicolumn{5}{c}{ Animal } \\
\hline Periodo & 1 & 2 & 3 & 4 \\
I & D & A & B & C \\
II & A & C & D & B \\
III & B & D & C & A \\
IV & C & B & A & D \\
\hline
\end{tabular}

Fonte: $\operatorname{Cox}(1958)$

A análise estatística foi realizada no proc GLM do programa estatístico SAS (1988). Os dados referentes ao $\mathrm{pH}, \mathrm{AGV}, \mathrm{N}-\mathrm{NH}_{3}$ e uréia plasmática foram agrupados em dois períodos ( 0 -10 horas e 12-22 horas) e então analisados entre os tempos de amostragem. A interpretação dos resultados foi feita através de análise de regressão polinomial para os tempos de amostragem, e comparação de médias para os tratamentos através do teste de Tukey em nivel de $5 \%$ de probabilidade.

Para efeito de análise adotou-se o modelo matemático dado por:

$Y_{i j k l}=\mu+a_{i}+p_{j}+t_{k}+\gamma_{i j k}+h_{l}+(h \times t)_{l k}+e_{i j k l}$

onde:

$\mathrm{Y}_{\mathrm{ijkl}}$ : observação relativa ao animal i, periodo j, tratamento $\mathrm{k}$ e hora $\mathrm{l}$; 
$\mu$ : média geral;

$a_{i}$ : efeito do animal i;

$p_{j}$ : efeito do periodo $j ;$

$t_{k}$ : efeito do tratamento $k$;

$\gamma_{\mathrm{jk}}$ : erro experimental associado às parcelas, suposto normal, independente, com média zero e variância $\sigma^{2}$;

$h_{1}$ : efeito de hora;

$(h \times t)_{1 k}$ : efeito da interação entre hora l e tratamento $k$;

$e_{i j k l}$ : erro experimental associado às sub-parcelas, suposto normal, independente, com média zero e variância $\sigma^{2}$.

$O$ efeito dos tratamentos, animais e periodos foram testados com 0 resíduo devido às parcelas. O efeito do tempo de coleta e a interação tempo de coleta $\mathrm{x}$ tratamentos foram testados com o resíduo das sub-parcelas conforme demonstra o quadro geral da análise da variância:

\begin{tabular}{lc}
\hline Causa de Variação & Graus de Liberdade \\
\hline Animal & 3 \\
Periodo & 3 \\
Tratamento (T) & 3 \\
Residuo (A) & 6 \\
\hline Parcelas & 15 \\
\hline Tempo de Coleta $(H)$ & 5 \\
T x H & 15 \\
Residuo (B) & 60 \\
\hline Total = Sub-parcelas & 95 \\
\hline
\end{tabular}

A análise da variância referente ao consumo MS foi realizado no proc GLM do programa estatístico SAS (1988). A comparação entre as médias dos tratamentos foi feita através do teste t-Student a $5 \%$ de probabilidade. 
Para efeito de análise adotou-se o seguinte modelo matemático:

$Y_{i j k}=\mu+a_{i}+p_{j}+t_{k}+e_{i j k}$

onde:

$\mathrm{Y}_{\mathrm{ijkl}}$ : observação relativa ao animal $\mathrm{i}$, periodo j, tratamento $\mathrm{k}$ e hora $\mathrm{l}$;

$\mu$ : média geral;

$a_{i}$ : efeito do animal $i$;

$\mathrm{p}_{\mathrm{j}}$ : efeito do periodo $\mathrm{j}$;

$t_{k}$ : efeito do tratamento $k$;

$\gamma_{\mathrm{ijk}}$ : erro experimental associado a observação $Y_{\mathrm{ijk} k}$

\subsection{Fases experimentais}

O periodo experimental constituiu-se de quatro sub-periodos com 15 dias cada um. Os dez primeiros dias corresponderam a adaptação dos animais aos tratamentos, e os cinco dias restantes destinaram-se a amostragem do alimento oferecido e das sobras. A amostragem do fluido ruminal e sangue foram realizadas no $15^{\circ} \mathrm{dia}$. No final de cada sub-periodo, os animais eram pesados e então, submetidos ao rodízio nas dietas conforme estabelecido no delineamento experimental utilizado.

\subsection{Amostragem dos dados referentes ao consumo de matéria seca}

O alimento oferecido e as sobras foram amostrados uma vez por dia, de modo a formar uma amostra composta para cada animal e tratamento. A quantidade de sobras amostradas correspondia a $5 \%$ do total recusado; do alimento oferecido amostrou-se uma quantidade previamente fixada. As amostras foram acondicionadas em sacos plásticos identificados e estocadas a $-20^{\circ} \mathrm{C}$ para posterior análise bromatológica. 


\subsection{Amostragem de fluido ruminal para determinação do $\mathrm{pH}, \mathrm{AGV}$ e $\mathrm{N}-\mathrm{NH}_{3}$}

As amostragens de fluido ruminal foram realizadas $0,2,4,6,8,10,12$, $14,16,18,20$ e 22 horas. As amostras nos tempos 0 e 12 foram obtidas antes do fornecimento das dietas aos animais.

As amostras de conteúdo ruminal foram filtradas em quatro camadas de tecido de algodão, obtendo-se aproximadamente $300 \mathrm{ml}$ de filtrado. Destes, foram retiradas três alíquotas de $50 \mathrm{ml}$, sendo uma destinada a determinação imediata do $\mathrm{pH}$ e as outras duas armazenadas a $-20^{\circ} \mathrm{C}$ sem $\circ$ uso de preservativos (Nocek et al., 1986) para posterior análises de AGV e N-NH

\subsection{Amostragem sangüínea para determinação da uréia plasmática}

As amostras de sangue foram realizadas $0,2,4,6,8,10,12,14,16,18$, 20 e 22 horas após a alimentação. As amostras nos tempos 0 e 12 foram realizadas antes do fornecimento das dietas aos animais.

O sangue foi colhido por vasopunção da veia mamária, utilizando-se sistema de coleta a vácuo em tubos de vidro siliconizados providos de rolha de borracha. Utilizou-se um tubo para cada animal com capacidade para $10 \mathrm{ml}$ de sangue, com heparina sódica como anticoagulante para a obtenção do plasma.

As amostras foram submetidas a centrifugação a $1400 \mathrm{G}$ por 15 minutos para a obtenção do plasma. Após realização de tal processo, as amostras foram acondicionadas a $-20^{\circ} \mathrm{C}$ para posterior determinação analítica.

\subsection{Análises químico-bromatológicas}

As amostras da cana-de-açúcar, farelo de soja, alimento oferecido e sobras foram secas à temperatura de $60^{\circ} \mathrm{C}$ em estufa com circulação forçada de ar, por um período mínimo de 48 horas. Posteriormente, foram moídas em 
moinho do tipo Willey com peneira de malha de $1 \mathrm{~mm}$ de diâmetro e armazenadas em sacos plásticos devidamente identificados.

Os teores de matéria seca, matéria mineral e proteina bruta (micro Kjeldahl) foram realizadas de acordo com as metodologias descritas por AOAC (1990).

As determinações de fibra em detergente neutro (FDN) e fibra em detergente ácido (FDA) foram feitas segundo Goering \& Van Soest (1970).

\subsection{Determinação do $\mathrm{pH}$}

Os valores de $\mathrm{pH}$ das amostras do fluido ruminal foram determinados imediatamente após a coleta em potenciômetro digital da marca Digimed, modelo TE - 902.

\subsection{Determinação dos ácidos graxos voláteis (AGV)}

As amostras de fluido ruminal foram submetidas a centrifugação a 17000 $G$ por dez minutos. Em seguida, transferiu-se $0,8 \mathrm{ml}$ do sobrenadante para um frasco de vidro tipo "Snap Cap", adicionados de 0,2 $\mathrm{ml}$ de ácido metafosfórico mais $0,1 \mathrm{ml}$ de uma solução padrão conhecida (padrão interno). As amostras foram armazenadas $\mathrm{a}-14^{\circ} \mathrm{C}$ para posterior leitura.

As determinações quantitativas e qualitativas dos AGV foram feitas segundo Erwin et al. (1961), através de cromatografia gasosa. Utilizou-se um cromatógrafo a gás Hewlett Packard 5890 série II acoplado a um integrador Hewlett Packard 3396 série II. O gás cromatócrafo era equipado com coluna de alumínio de seis pés de comprimento e $1 / 4$ de polegada de diâmetro, empacotada com carbopack, e com detector de ionização de chamas. Os gases utilizados foram: arraste - nitrogênio na vazão de $20 \mathrm{ml} \cdot \mathrm{min}^{-1}$; comburente oxigênio na vazão de $400 \mathrm{ml} \cdot \mathrm{min}^{-1}$; combustivel - hidrogênio na vazão de 30 
$\mathrm{ml} \cdot \mathrm{min}^{-1}$. As temperaturas de operação do vaporizador, da coluna de separação e do detector foram, respectivamente $160^{\circ} \mathrm{C}, 110^{\circ} \mathrm{C}$ e $190^{\circ} \mathrm{C}$.

As concentrações foram determinadas mediante a injeção dos $0,8 \mathrm{ml}$ da amostra adicionados de $0,2 \mathrm{ml}$ de ácido metafosfórico mais $0,1 \mathrm{ml}$ do padrão interno. A solução padrão foi injetada a cada dez injeções sucessivas de amostras de fluido ruminal com o objetivo de evitar distorções nas leituras.

Os resultados foram obtidos através de um integrador que utilizou o padrão interno como base de comparação entre as amostras. O padrão interno era composto por $60,66 \%$ de ácido acético $\left(C_{2}\right), 21,19 \%$ de ácido propiônico $\left(\mathrm{C}_{3}\right), 15,62 \%$ de ácido butírico $\left(\mathrm{C}_{4}\right), 2,02 \%$ de ácido isobutírico $\left(\mathrm{iC}_{4}\right), 3,75 \%$ de ácido valérico $\left(\mathrm{C}_{5}\right)$ e $3,52 \%$ de ácido isovalérico $\left(\mathrm{iC}_{5}\right)$.

\subsection{Determinação do nitrogênio amoniacal $\left(\mathrm{N}-\mathrm{NH}_{3}\right)$}

A determinação das concentrações de $\mathrm{N}-\mathrm{NH}_{3}$ no fluido ruminal foi feita de acordo com Chaney \& Marbach (1962).

Para tal, as amostras de fluido ruminal foram submetidas a centrifugação a $17000 \mathrm{G}$ por dez minutos. Em seguida, pipetou-se $40 \mu \mathrm{l}$ do sobrenadante da amostra nos tubos de ensaio, adicionou-se $2,5 \mathrm{ml}$ de fenol mais $5,0 \mathrm{ml}$ de hipoclorito de sódio. Os tubos foram incubados em banho- maria a $37^{\circ} \mathrm{C}$ (previamente estabilizados) por dez minutos. De cada tubo, foram pipetados $300 \mu \mathrm{l}$ da amostra para as placas de microtítulo.

As leituras da absorbância foram realizadas em aparelho do tipo "Elisa Reader", modelo 3550, com lâmpada de $540 \mathrm{~nm}$. Os valores de absorbância foram automaticamente utilizados em equação de regressão linear $e$ convertidos em mg de N-NH $\mathrm{N}_{3} \cdot \mathrm{dl}^{-1}$. 


\subsection{Determinação da uréia plasmática}

A concentração de uréia plasmática foi determinada através do método da urease, descrito por Talke \& Schubert (1965), usando-se kit comercial. As determinações foram processadas com o auxílio do analisador bioquímico automático, Bayer-Technicron ${ }^{\circledR}$, modelo RA - $100^{\mathrm{TM}}$ System, e os resultados foram expressos em mg.dl-1. 


\section{RESULTADOS E DISCUSSĀO}

\subsection{Consumo de matéria seca (MS)}

Os resultados médios do consumo de MS dos animais são exibidos na Tabela 3 .

Os valores obtidos para o consumo de MS indicaram diferenças $(P<0,05)$ entre os tratamentos. Os animais submetidos ao tratamento $A$ apresentaram maior consumo $(7,76 \mathrm{~kg})$ quando comparados com os animais que receberam os demais tratamentos.

Tabela 3. Valores médios do consumo de MS $(\mathrm{kg})$ dos animais distribuídos nos tratamentos adotados.

\section{Tratamentos}

$\begin{array}{llll}\text { A } & \text { B } & \text { C } & \text { D }\end{array}$

MS (kg) $7,76( \pm 1,65)^{\star} a \quad 4,94( \pm 1,51) b \quad 4,53( \pm 0,89) b \quad 4,02( \pm 0,43) b$

Médias seguidas de letras minúsculas distintas nas linhas indicam diferenças significativas entre os tratamentos $(P<0,05)$

* desvio padrão da média

Segundo Van Soest (1994) na maioria das dietas com forragens, as necessidades metabólicas e fisiológicas do animal não são atendidas em função da qualidade da dieta que induzem a valores de consumo inferiores.

Nas dietas com cana-de-açúcar, a principal limitação da produtividade animal está associada ao baixo consumo de MS devido ao mecanismo de 
enchimento do rúmen (Preston, 1981 e Leng, 1988). Para Boin \& Tedeschi (1993) o fator determinante dessas dietas é o baixo teor de nitrogênio.

Entretanto, a elevação do teor protéico no tratamento C $(15,85 \%$ PB) e D $(19,82 \%$ PB) não refletiram em aumento de consumo, e sim tenderam ao decréscimo. Por outro lado, os tratamentos A $(11,62 \%$ PB) e $B(11,42 \%$ PB) apresentavam teores protéico semelhantes entretanto, o consumo da dieta constituida por farelo de soja foi maior. A diminuição da ingestão de alimentos devido a quantidades elevadas de uréia tem sido associada a palatabilidade. (Boin, 1984).

Os resultados obtidos no presente experimento para o consumo de MS foram semelhantes aos obtidos por Aroeira et al. (1993) que encontraram 6,7 kg e 7,0 kg de MS consumida quando o suplemento foi respectivamente, farelo de algodão e farelo de arroz; destacando assim, a superioridade da ingestão de MS em função da suplementação com uma fonte protéica de origem vegetal.

Rodrigues (1985) não encontrou diferença no consumo de MS de novilhas leiteiras alimentadas com teores de uréia $(0,5 ; 1,0$ e 1,5\% na matéria original); embora houvesse uma tendência das maiores ingestões estarem relacionadas aos teores mais elevados de uréia.

\section{$4.2 \mathrm{pH}$ ruminal}

$\mathrm{Na}$ Tabela 4 são demonstrados os valores médios do $\mathrm{pH}$ do fluido ruminal. As equações de regressão ajustadas em função dos tempos de amostragem são ilustradas pelas Figuras 1, 2, 3 e 4.

Não foram observadas diferenças $(P>0,05)$ entre os tratamentos no $\mathrm{pH}$ do fluido ruminal para o período 0-10 horas.

Os resultados observados entre os tempos de amostragem revelaram efeito quadrático $(P<0,05)$ para os tratamentos $A$ e $B$. $O$ valor mínimo de $p H$ ruminal foi observados 5,75 horas após a alimentação para os animais 
Tabela 4. Valores médios do $\mathrm{pH}$ do fluido ruminal de acordo com as dietas experimentais e os tempos de amostragem.

\begin{tabular}{|c|c|c|c|c|c|c|c|c|}
\hline \multirow{2}{*}{$\begin{array}{c}\text { Dietas } \\
0\end{array}$} & \multicolumn{6}{|c|}{ Tempo (horas) } & \multicolumn{2}{|c|}{ Efeito $^{1}$} \\
\hline & 2 & 4 & 6 & 8 & 10 & Média & $\mathrm{L}$ & Q \\
\hline $\begin{array}{rr}\text { A } & 7,25 \\
\pm 0,07^{*}\end{array}$ & $\begin{array}{r}6,84 \\
\pm 0,32\end{array}$ & $\begin{array}{r}6,95 \\
\pm 0,26\end{array}$ & $\begin{array}{r}6,88 \\
\pm 0,29\end{array}$ & $\begin{array}{r}6,94 \\
\pm 0,30\end{array}$ & $\begin{array}{r}7,00 \\
\pm 0,21\end{array}$ & $\begin{array}{r}\quad 6,98 \mathbf{a} \\
\pm 0,14\end{array}$ & NS & $0,00006^{2}$ \\
\hline B $\begin{array}{r}7,33 \\
\pm 0,25\end{array}$ & $\begin{array}{r}6,97 \\
\pm 0,30\end{array}$ & $\begin{array}{r}7,08 \\
\pm 0,22\end{array}$ & $\begin{array}{r}6,97 \\
\pm 0,31\end{array}$ & $\begin{array}{r}7,06 \\
\pm 0,29\end{array}$ & $\begin{array}{r}7,11 \\
\pm 0,24\end{array}$ & $\begin{array}{c}7,09 \mathbf{a} \\
\pm 0,12\end{array}$ & NS & $0,00015^{3}$ \\
\hline C $\begin{array}{r}7,17 \\
\pm 0,18\end{array}$ & $\begin{array}{r}7,13 \\
\pm 0,13\end{array}$ & $\begin{array}{r}7,01 \\
\pm 0,20\end{array}$ & $\begin{array}{r}7,04 \\
\pm 0,10\end{array}$ & $\begin{array}{r}7,02 \\
\pm 0,08\end{array}$ & $\begin{array}{r}7,06 \\
\pm 0,03\end{array}$ & $\begin{aligned} & 7,07 \mathbf{a} \\
\pm & 0,06\end{aligned}$ & NS & NS \\
\hline $\begin{array}{r}7,24 \\
\pm 0,19\end{array}$ & $\begin{array}{r}7,16 \\
\pm 0,18\end{array}$ & $\begin{array}{r}7,18 \\
\pm 0,24\end{array}$ & $\begin{array}{r}7,09 \\
\pm 0,16\end{array}$ & $\begin{array}{r}7,11 \\
\pm 0,17\end{array}$ & $\begin{array}{r}7,16 \\
\pm 0,21\end{array}$ & $\begin{aligned} & 7,16 \mathbf{a} \\
& \pm 0,05\end{aligned}$ & NS & NS \\
\hline
\end{tabular}
Tempo (horas) Efeito $^{1}$

Dietas 12

\begin{tabular}{llllllll}
\hline 14 & 16 & 18 & 20 & 22 & Média & L & Q
\end{tabular}

\begin{tabular}{rrrrrrrlll}
\hline A & 7,12 & 6,81 & 6,84 & 6,93 & 6,88 & 7,06 & $6,94 \mathbf{b}$ & NS & $0,00013^{4}$ \\
& $\pm 0,35$ & $\pm 0,18$ & $\pm 0,20$ & $\pm 0,20$ & $\pm 0,36$ & $\pm 0,23$ & $\pm 0,12$ & & \\
B & 7,16 & 7,06 & 6,98 & 7,07 & 7,12 & 7,18 & $7,10 \mathbf{a b}$ & NS & $0,00013^{4}$ \\
$\pm 0,13$ & $\pm 0,26$ & $\pm 0,16$ & $\pm 0,24$ & $\pm 0,22$ & $\pm 0,26$ & $\pm 0,07$ & & \\
C & 7,09 & 7,02 & 7,00 & 6,96 & 7,00 & 7,01 & $7,01 \mathbf{a b}$ & NS & $0,00013^{4}$ \\
$\pm 0,14$ & $\pm 0,04$ & $\pm 0,08$ & $\pm 0,12$ & $\pm 0,17$ & $\pm 0,29$ & $\pm 0,04$ & & \\
D 7,20 & 7,05 & 7,08 & 7,07 & 7,10 & 7,17 & $7,11 \mathbf{a}$ & NS & $0,00013^{4}$ \\
$\pm 0,13$ & $\pm 0,19$ & $\pm 0,15$ & $\pm 0,19$ & $\pm 0,18$ & $\pm 0,26$ & $\pm 0,06$ & &
\end{tabular}

Médias seguidas por letras minúsculas distintas nas colunas, indicam diferenças significativas entre os tratamentos $(\mathrm{P}<0,05)$; 'Efeito: $\mathrm{L}=$ linear; $\mathrm{Q}=$ quadrático; $\mathrm{NS}=$ não significativo $(\mathrm{P}>0,05)$

* desvio padrão da média

$$
\begin{aligned}
2 & r^{2}=0,6643 \\
{ }^{3} r^{2} & =0,6462 \\
{ }^{4} r^{2} & =0,8564
\end{aligned}
$$


que receberam o tratamento $A(\mathrm{pH} \mathrm{6,86)}$, e, às 5,78 horas para os animais submetidos ao tratamento $B(\mathrm{pH} \mathrm{6,98)}$.

A interação tratamento $x$ tempos de amostragem foi significativa $(P<0,05)$. Os tempos de amostragem tiveram efeitos diferentes sobre os tratamentos.

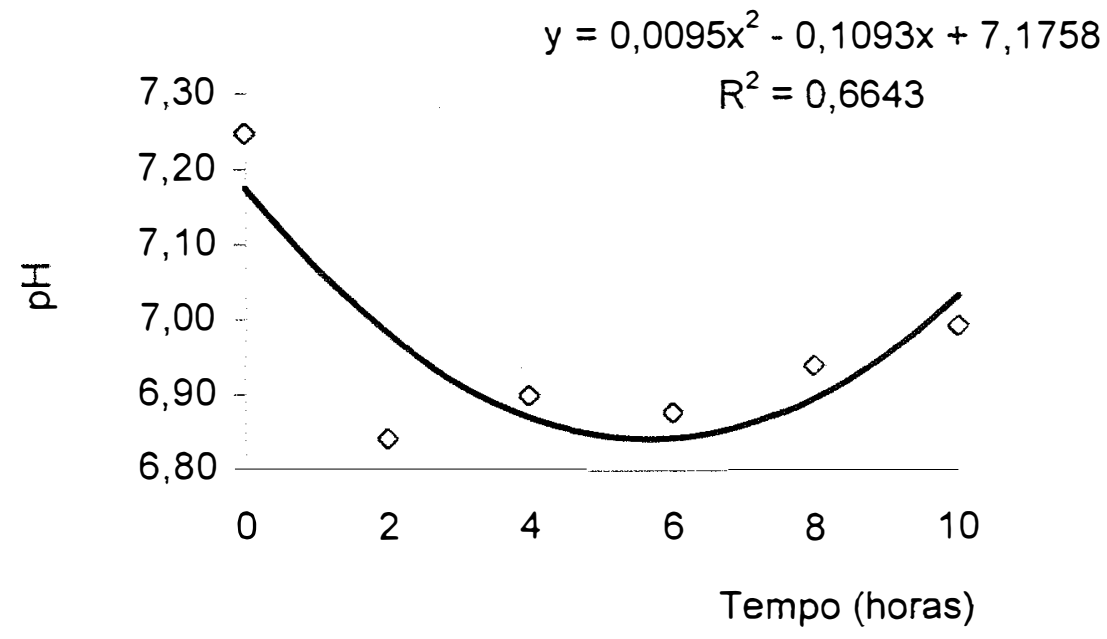

Figura 1. Equação de regressão ajustada em função dos tempos de amostragem para a dieta $A$.

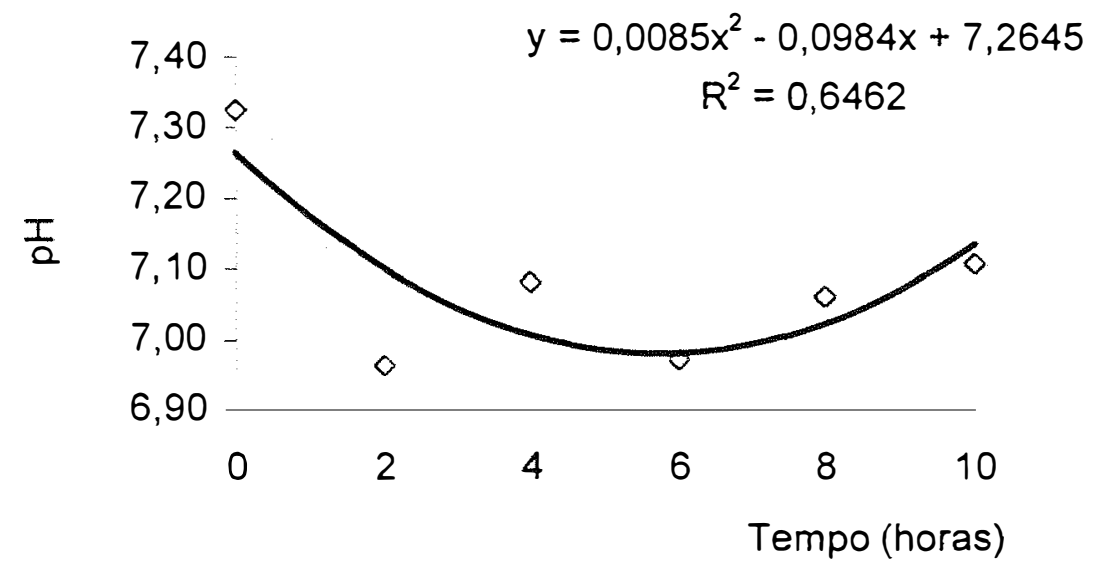

Figura 2. Equação de regressão ajustada em função dos tempos de amostragem para a dieta $B$. 
Em relação ao periodo $12-22$ horas verificou-se diferenças $(P<0,05)$ entre os tratamentos no $\mathrm{pH}$ do fluido ruminal. Os animais que receberam o tratamento $D(7,11)$ apresentaram $\mathrm{pH}$ ruminal superior aos que receberam o tratamento $A(6,94)$. Os tratamentos $B(7,10)$ e $C(7,01)$ não diferiram entre si e nem entre $A$ e $D$ para essa variável.

Os resultados observados entre os tempos de amostragem revelaram efeito quadrático $(P<0,05)$ para todos os tratamentos. O menor valor encontrado para o $\mathrm{pH}(6,96)$ foi observado às 17,13 horas.

Não houve interação entre tratamento $x$ tempos de amostragem $(P>0,05)$. Para $\circ \mathrm{pH}$ ruminal os tempos de amostragem tiveram efeitos iguais $(P>0,05)$ sobre os tratamentos.

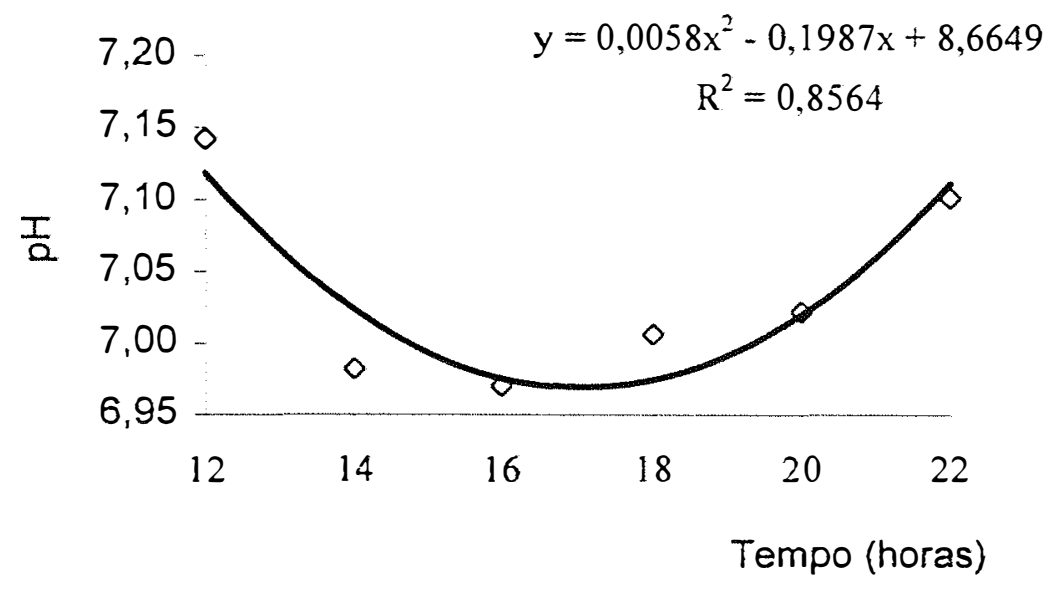

Figura 3. Equação de regressão ajustada em função dos tempos de amostragem para todas as dietas.

Os resultados médios observados para $\circ \mathrm{pH}$ permaneceram durante todo o tempo de amostragem acima de 6,0, não interferindo assim, provavelmente na atuação das bactérias celulolíticas (Slyter, 1986). Os valores médios de $\mathrm{pH}$ determinados no presente experimento foram relativamente altos provavelmente devido a dieta com cana-de-açúcar estimular a salivação, uma 
vez que grande parte do tempo é despendido com a mastigação e ruminação (Preston \& Leng, 1981).

Entretanto, observou-se uma variação cíclica nos valores de $\mathrm{pH}$ seguido de uma redução após a alimentação, como conseqüência da atividade microbiana no rúmen. Logo após o fornecimento dos alimentos, ocorre uma maior disponibilidade de nutrientes para os microrganismos do rúmen e a taxa de fermentação eleva-se, aumentando a produção de AGV.

Tal situação foi evidenciada por Owens \& Goetsch (1988), segundo os quais, o intervalo de tempo compreendido entre meia e quatro horas após a alimentação caracteriza-se por uma diminuição do $\mathrm{pH}$, refletindo o balanço entre a taxa de produção de AGV, ação tamponante da saliva e/ou liberação de bases presentes nos alimentos.

Os dados aqui obtidos foram semelhantes aos verificados por Losada et al., 1979 que encontraram valores de $\mathrm{pH} 7,0 ; 7,5 ; 7,75$ e 7,05, respectivamente para os teores $0 ; 7 ; 14$ ou $21 \%$ de uréia na solução de melaço.

Manzano et al. (1983) não observaram diferenças para o pH ruminal que pudessem ser atribuídas ao efeito da suplementação com farelo de soja. Os valores determinados foram 6,$82 ; 6,46 ; 6,35$ e 6,66, respectivamente para os teores crescentes de farelo de soja empregados.

\subsection{Concentração de ácidos graxos voláteis totais (AGV totais)}

$\mathrm{Na}$ Tabela 5 estão expressos os valores médios da concentração total de AGV no fluido ruminal. As equações de regressão ajustadas em função dos tempos de amostragem são ilustrados pelas Figuras 4 e 5.

Não foram observadas diferenças $(P>0,05)$ entre os tratamentos para a concentração de AGV totais; ocorreu, apenas, uma alteração na proporção de AGV. 
Tabela 5. Valores médios da concentração de $A G V$ totais $\left(m M \cdot L^{-1}\right)$ no fluido ruminal de acordo com as dietas experimentais e os tempos de amostragem.

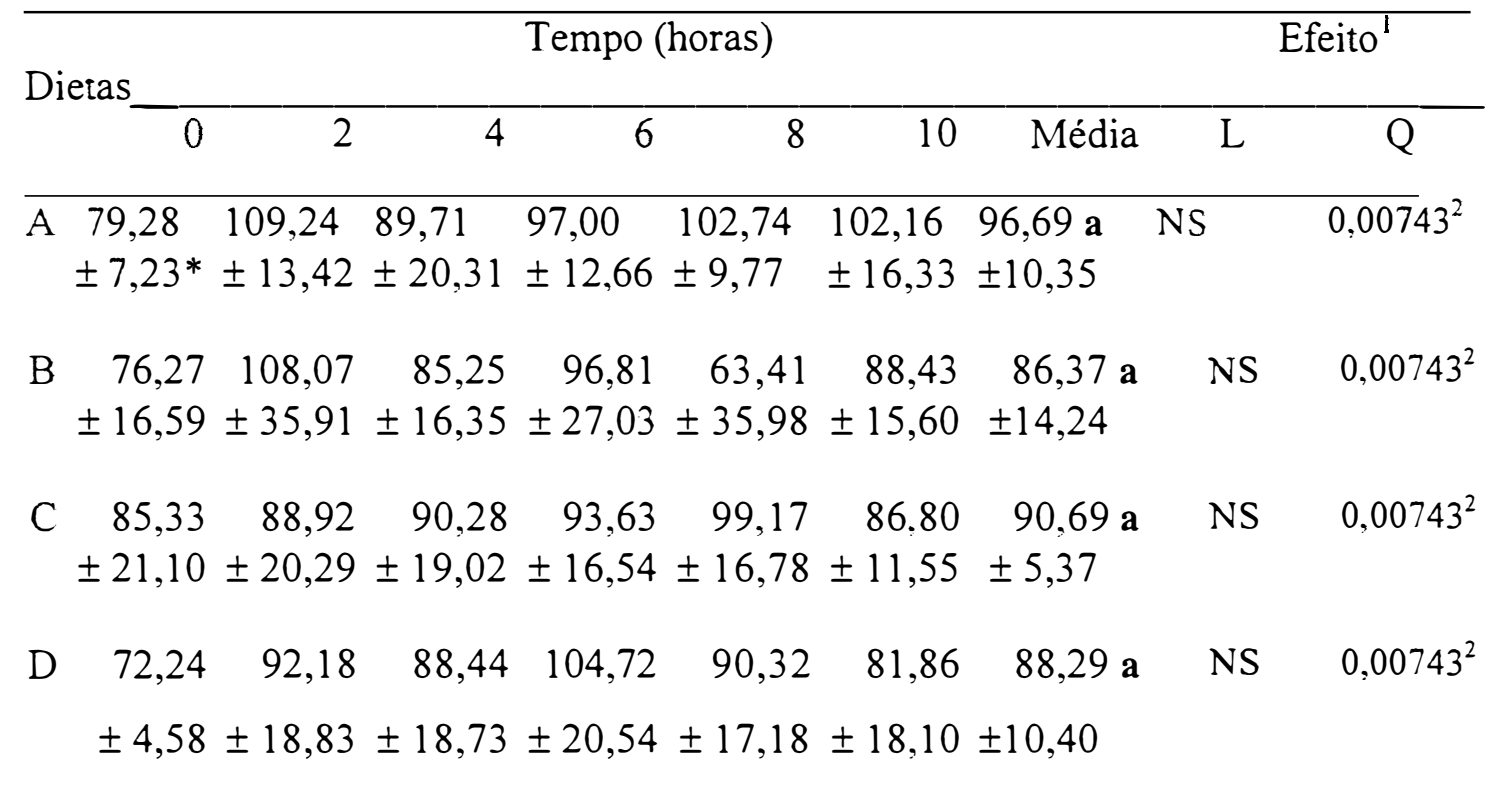

Dietas

$$
\text { Tempo (horas) Efeito }{ }^{1}
$$

\begin{tabular}{lrrrrrrrrc} 
& 12 & 14 & 16 & 18 & 20 & 22 & Média & L & Q \\
\hline A & 87,88 & 106,86 & 100,04 & 96,70 & 97,38 & 96,30 & 97,53 a & NS & $0,00295^{3}$ \\
& $\pm 19,53 \pm 14,62$ & $\pm 6,32$ & $\pm 3,34$ & $\pm 3,09$ & $\pm 7,89$ & $\pm 6,14$ & & \\
B & 84,69 & 95,85 & 100,55 & 87,12 & 90,12 & 85,32 & 90,61 a & NS & $0,00295^{3}$ \\
& $\pm 12,43$ & $\pm 18,25$ & $\pm 11,70$ & $\pm 6,25$ & $\pm 16,75$ & $\pm 23,54$ & $\pm 6,35$ & & \\
& & & & & & & & \\
C $\quad 83,40$ & 98,42 & 99,84 & 93,04 & 81,60 & 91,37 & 91,27 a & NS & $0,00295^{3}$ \\
& $\pm 15,75 \pm 20,59 \pm 13,45 \pm 20,31 \pm 23,68$ & $\pm 9,48$ & $\pm 7,52$ & & \\
D & 79,82 & 95,65 & 86,54 & 96,70 & 89,84 & 89,32 & 89,65 a & NS & $0,00295^{3}$ \\
& $\pm 9,82 \pm 18,77 \pm 10,48 \pm 21,31 \pm 18,44 \pm 23,61$ & $\pm 6,20$ & &
\end{tabular}

Médias seguidas por letras minúsculas distintas nas colunas, indicam diferenças significativas entre os tratamentos $(\mathrm{P}<0,05)$; 'Efeito: $\mathrm{L}=$ linear; $\mathrm{Q}=$ quadrático; $\mathrm{NS}=$ não significativo $(\mathrm{P}>0,05)$

* desvio padrão da média

${ }^{2} r^{2}=0,4138$
${ }^{3} r^{2}=0,4757$ 
Quando comparados os resultados entre os tempos de amostragem, verificou-se efeito quadrático $(P<0,05)$ para todos os tratamentos. No período 0 10 horas, a maior concentração de $A G V$ totais $\left(95,55 \mathrm{mM}^{\left.-L^{-1}\right)}\right.$ foi observada 5,6 horas após a alimentação.

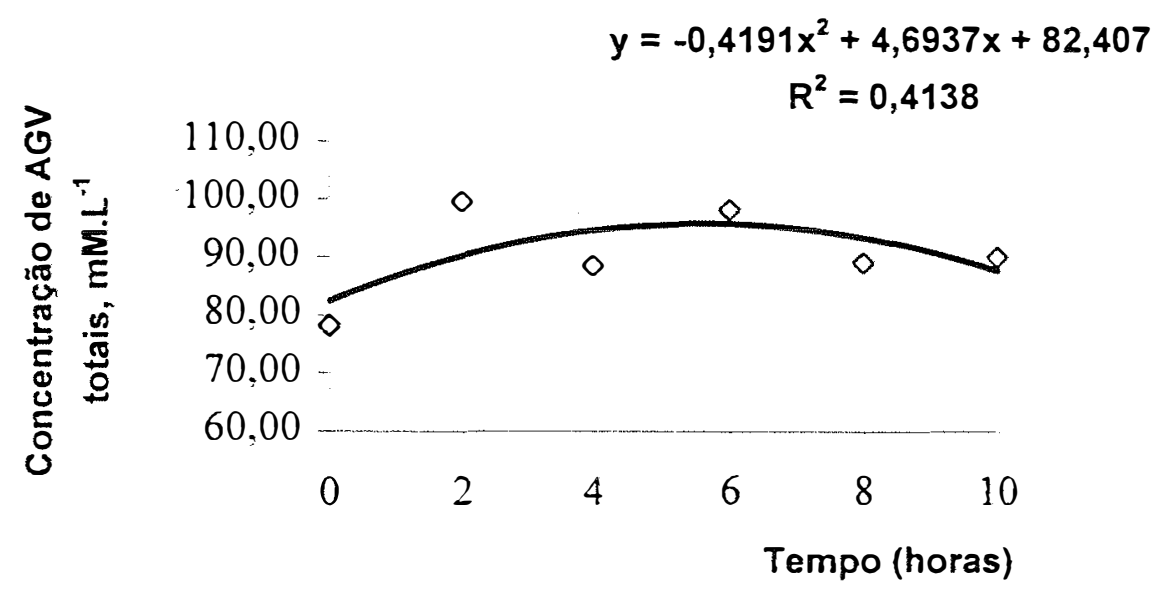

Figura 4. Equação de regressão ajustada em função dos tempos de amostragem para todas as dietas.

Entre 12-22 horas, a maior concentração de AGV totais $\left(96,36 \mathrm{mM} \cdot \mathrm{L}^{-1}\right)$ foi verificada às 17,13 horas.

Não houve efeito $(P>0,05)$ para a interação tratamento tempos de amostragem. Os tempos de amostragem tiveram efeitos iguais sobre os tratamentos.

Os resultados obtidos para a concentração de AGV totais permaneceram entre os valores 60-150 mM.L-1 citados por Owens \& Goetsch (1988). Entretanto, foram inferiores aos verificados por Preston \& Leng (1981) que encontraram valores de 120-150 mM.L ${ }^{-1}$ em dietas com cana-de-açúcar. 


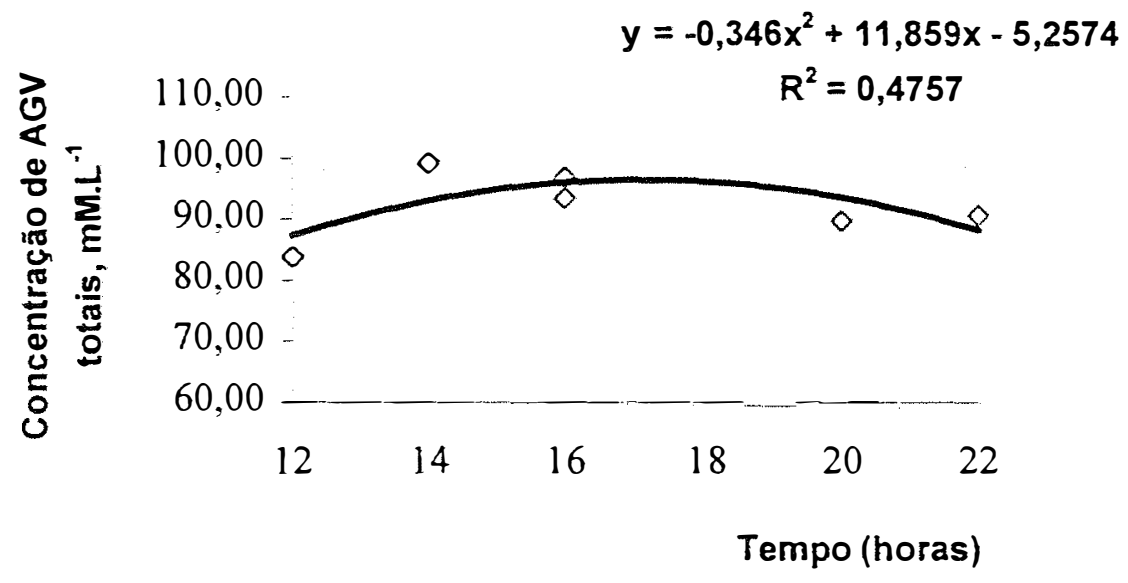

Figura 5. Equação de regressão ajustada em função dos tempos de amostragem para todas as dietas

De maneira semelhante ao encontrado no presente experimento, Aroeira et al.(1993) não observaram diferenças entre os tratamentos nas concentrações de AGV totais; entretanto ocorreram diferenças entre os tempos de amostragem.

Os resultados médios das concentraçōes de AGV totais 97,$11 ; 88,49$; 90,98 e $88,97{\mathrm{mM} . \mathrm{L}^{-1}}^{-1}$ de fluido ruminal, respectivamente para os tratamentos $A$, $B, C$ e D foram superiores aos obtidos por Losada (1979) os quais observaram concentrações de 70,$00 ; 74,00 ; 79,50$ e 91,00 mM.L-1 em função do aumento dos teores de uréia na solução de melaço.

Valdez et al. (1977) não verificaram diferenças para AGV totais em função da suplementação com polidura de arroz. Os valores médios de AGV totais encontrados variaram entre 75 e $115 \mathrm{mM} . \mathrm{L}^{-1}$ de fluido ruminal. 


\section{4 Ácido acético}

A Tabela 6 apresenta os valores médios da porcentagem de ácido acético no fluido ruminal. As equações de regressão ajustadas em função dos tempos de amostragem são ilustrados pelas Figuras 6 e 7.

Não foram observadas diferenças $(P>0,05)$ para a porcentagem de ácido acético entre os tratamentos. No entanto, quando comparados os resultados entre os tempos de amostragem, verificou-se efeito quadrático $(P<0,05)$ para todos os tratamentos, em ambos periodos. Entre 0-10 horas, a menor porcentagem de ácido acético $(60,85 \%)$ foi observada 5,93 horas após a alimentação. No periodo $12-22$ horas a menor porcentagem $(60,52 \%)$ foi verificada 16,87 horas.

A interação tratamento $x$ tempos de amostragem não foi significativa $(P>0,05)$ para a porcentagem de ácido acético. Os tratamentos foram igualmente influenciados pelos tempos de amostragem.

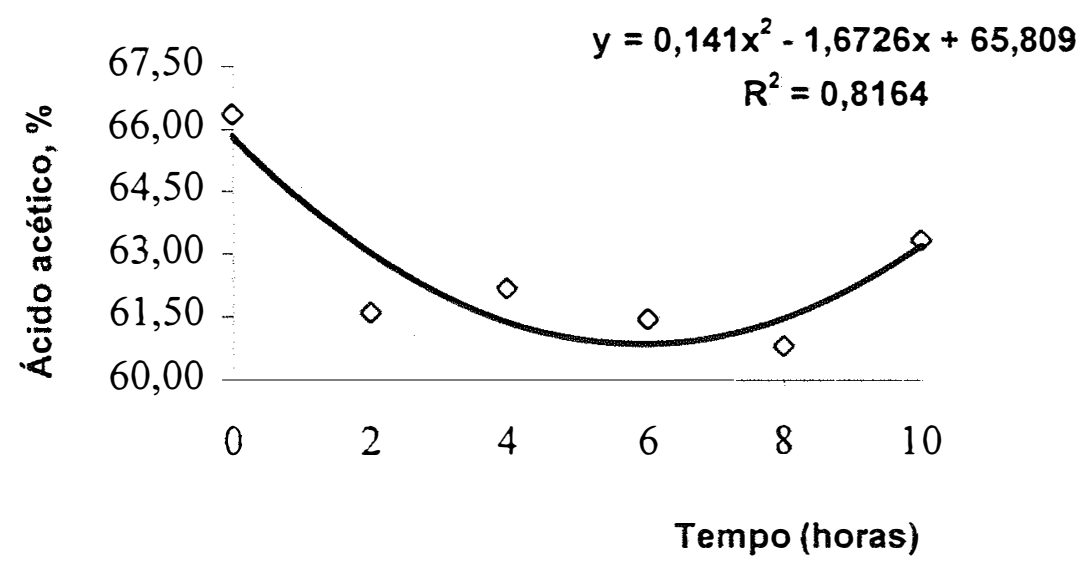

Figura 6. Equação de regressão ajustada em função dos tempos de amostragem para todas as dietas. 
Tabela 6. Valores médios da porcentagem de ácido acético no fluido ruminal de acordo com as dietas experimentais e os tempos de amostragem.

\begin{tabular}{|c|c|c|c|c|c|c|c|c|c|}
\hline \multirow{2}{*}{\multicolumn{2}{|c|}{ Dietas }} & \multicolumn{6}{|c|}{ Tempo (horas) } & \multicolumn{2}{|c|}{ Efeito $^{1}$} \\
\hline & & 2 & 4 & 6 & 8 & 10 & Média & $\mathrm{L}$ & $\mathrm{Q}$ \\
\hline A & $\begin{array}{r}67,98 \\
\pm 1,86^{*}\end{array}$ & $\begin{aligned} & 61,29 \\
\pm & 3,41\end{aligned}$ & $\begin{array}{r}62,68 \\
\pm 4,33\end{array}$ & $\begin{aligned} & 62,38 \\
\pm & 3,69\end{aligned}$ & $\begin{aligned} & 60,53 \\
\pm & 6,32\end{aligned}$ & $\begin{aligned} & 64,72 \\
\pm & 2,74\end{aligned}$ & $\begin{array}{c}63,26 \mathbf{a} \\
\pm 2,71\end{array}$ & NS & $0,00001^{2}$ \\
\hline B & $\begin{array}{r}64,79 \\
\pm 4,99\end{array}$ & $\begin{array}{r}60,04 \\
\pm 6,26\end{array}$ & $\begin{array}{r}60,14 \\
\pm 4,25\end{array}$ & $\begin{array}{r}59,92 \\
\pm 3,83\end{array}$ & $\begin{array}{r}60,01 \\
\pm 2,16\end{array}$ & $\begin{array}{r}62,50 \\
\pm 3,81\end{array}$ & $\begin{array}{l}61,23 \mathbf{a} \\
\pm 2,00\end{array}$ & NS & $0,00001^{2}$ \\
\hline C & $\begin{array}{r}64,72 \\
\pm 3,62\end{array}$ & $\begin{array}{r}61,29 \\
\pm 1,96\end{array}$ & $\begin{array}{r}62,18 \\
\pm 1,92\end{array}$ & $\begin{array}{r}60,25 \\
\pm 3,84\end{array}$ & $\begin{array}{r}59,56 \\
\pm 3,07\end{array}$ & $\begin{array}{r}61,28 \\
\pm 2,25\end{array}$ & $\begin{array}{c}61,55 \mathbf{a} \\
\pm 1,80\end{array}$ & NS & $0,00001^{2}$ \\
\hline D & $\begin{array}{r}67,98 \\
\pm 1,60\end{array}$ & $\begin{array}{r}63,80 \\
\pm 3,94\end{array}$ & $\begin{array}{r}49,15 \\
\pm 28,50\end{array}$ & $\begin{array}{r}63,21 \\
\pm 1,55\end{array}$ & $\begin{array}{r}63,09 \\
\pm 1,50\end{array}$ & $\begin{array}{r}64,75 \\
\pm 1,97\end{array}$ & $\begin{array}{c}62,00 \mathrm{a} \\
\pm 6,55\end{array}$ & NS & $0,00001^{2}$ \\
\hline
\end{tabular}

Tempo (horas) $\quad$ Efeito $^{1}$

Dietas

\begin{tabular}{lllllllll}
\hline 12 & 14 & 16 & 18 & 20 & 22 & Média & L & Q
\end{tabular}

\begin{tabular}{rrrrrrrrll}
\hline A & 65,29 & 60,26 & 60,76 & 63,40 & 62,87 & 65,63 & 63,03 a & NS & $0,00001^{3}$ \\
& $\pm 2,67$ & $\pm 2,90$ & $\pm 2,96$ & $\pm 3,67$ & $\pm 1,88$ & $\pm 1,62$ & $\pm 2,23$ & & \\
& & & & & & & & & \\
B & 64,49 & 62,16 & 60,32 & 60,78 & 62,14 & 64,73 & 62,44 a & NS & $0,00001^{3}$ \\
& $\pm 3,83$ & $\pm 1,97$ & $\pm 2,29$ & $\pm 2,91$ & $\pm 2,77$ & $\pm 1,41$ & $\pm 1,84$ & & \\
& & & & & & & & & \\
C & 64,19 & 59,42 & 58,68 & 59,96 & 58,73 & 61,84 & 60,47 a & NS & $0,00001^{3}$ \\
& $\pm 2,98$ & $\pm 2,87$ & $\pm 3,67$ & $\pm 1,84$ & $\pm 2,03$ & $\pm 4,08$ & $\pm 2,16$ & & \\
& & & & & & & & \\
D & 65,91 & 60,99 & 62,48 & 62,19 & 64,30 & 65,95 & 63,64 a & NS & $0,00001^{3}$ \\
& $\pm 3,16$ & $\pm 0,94$ & $\pm 1,58$ & $\pm 3,19$ & $\pm 1,44$ & $\pm 2,50$ & $\pm 2,07$ & &
\end{tabular}

Médias seguidas por letras minúsculas distintas nas colunas, indicam diferenças significativas entre os tratamentos $(P<0,05)$; ${ }^{3}$ Eeito: $L=$ linear; $Q=$ quadrático; $N S=$ não significativo $(P>0,05)$

* desvio padrão da média

${ }^{2} r^{2}=0,8164$

${ }^{3} r^{2}=0,8633$ 


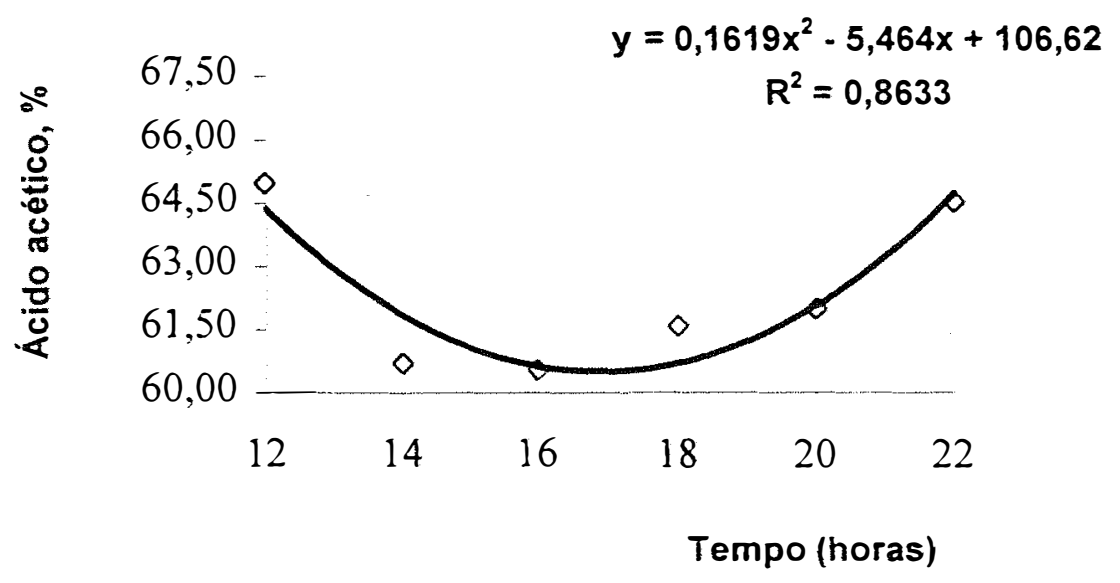

Figura 7. Equação de regressão ajustada em função dos tempos de amostragem para todas as dietas.

O decréscimo observado na proporção de ácido acético logo após a alimentação foi também verificado por Ferreiro et al. (1977) e Rodriguez et al. (1993).

De acordo Valdez et al. (1977), o decréscimo na proporção de ácido acético e o aumento na proporção de ácido propiônico após a alimentação seria relatado pela fermentação bacteriana dos açúcares solúveis presentes em grandes quantidades nas dietas com cana-de-açúcar.

As porcentagens médias aqui determinadas 63,$15 ; 61,84 ; 61,01$ e 62,82, respectivamente para os tratamentos $A, B, C$ e $D$, foram superiores as obtidas por Matos (1991) que encontrou 58,73; 55,59; 58,87 e 59,12 \% de ácido acético em dietas com cana-de-açúcar associados a dois niveis de ingestão e dois teores de uréia $(1,0$ e 1,5\%). 


\section{5 Ácido propiônico}

Os valores médios da porcentagem de ácido propiônico no fluido ruminal são apresentados na Tabela 7 . As equaçōes de regressão ajustadas em função dos tempos de amostragem são ilustrados pelas Figuras 8 e 9.

A porcentagem de ácido propiônico não diferiu entre os tratamentos $(P>0,05)$. Quando avaliados os resultados entre os tempos de amostragem, verificou-se efeito quadrático $(P<0,05)$ para todos os tratamentos em ambos períodos, nos quais as maiores porcentagens de ácido propiônico $(25,51 \%$ e $25,81 \%$ ) foram verificadas 5,83 e 16,14 horas; respectivamente, para os períodos 0-10 e 12-22 horas.

Os resultados da análise da variância não mostraram efeito $(P>0,05)$ para a interação tratamento $x$ tempos de amostragem. Para a porcentagem de ácido propiônico no rúmen, os tempos de amostragem tiveram efeitos iguais sobre os tratamentos.

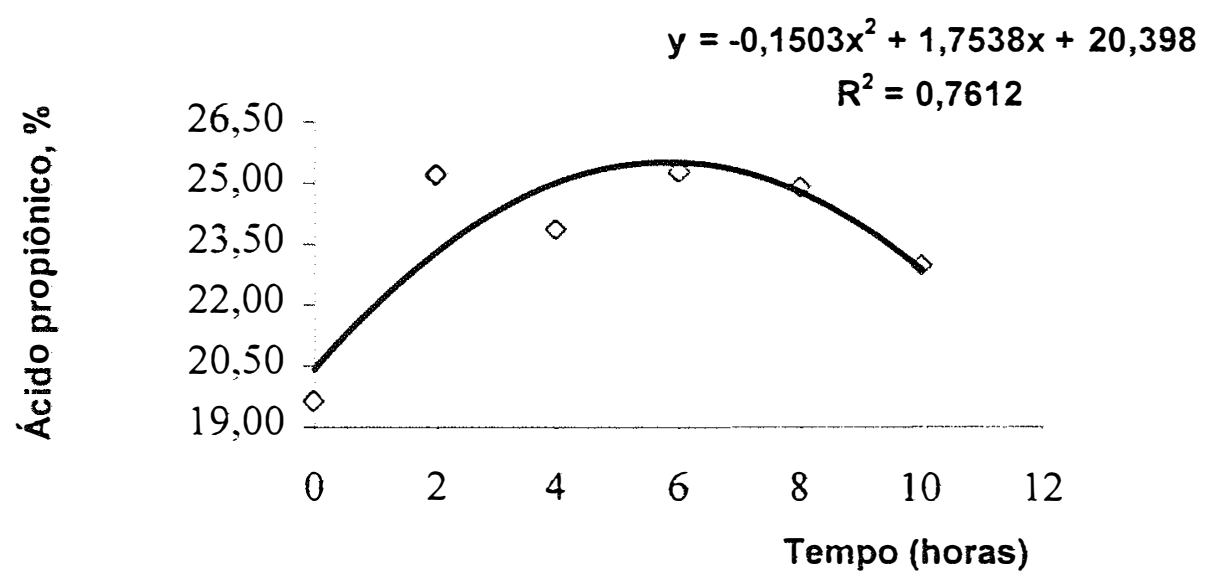

Figura 8. Equação de regressão ajustada em função dos tempos de amostragem para todas as dietas. 
Tabela 7. Valores médios da porcentagem de ácido propiônico no fluido ruminal de acordo com as dietas experimentais e os tempos de amostragem.

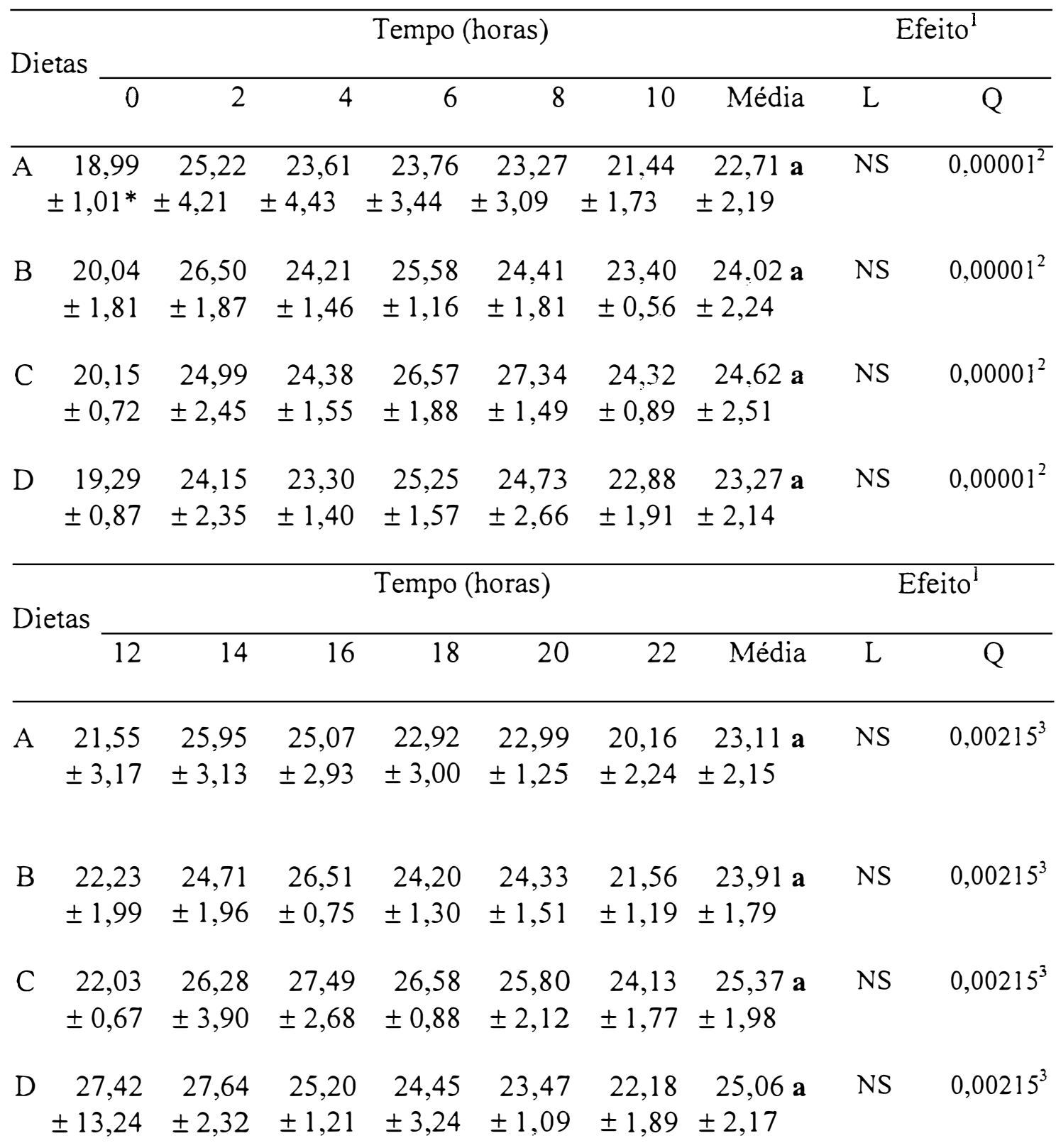

Médias seguidas por letras minúsculas distintas nas colunas, indicam diferenças significativas entre os tratamentos $(\mathrm{P}<0,05)$; ${ }^{1}$ Efeito: $\mathrm{L}=$ linear; $\mathrm{Q}=$ quadrático; $\mathrm{NS}=$ não significativo $(\mathrm{P}>0,05)$

* desvio padrão da média

${ }^{2} \mathrm{r}^{2}=0,7612$

${ }^{3} \mathrm{r}^{2}=0,8537$ 


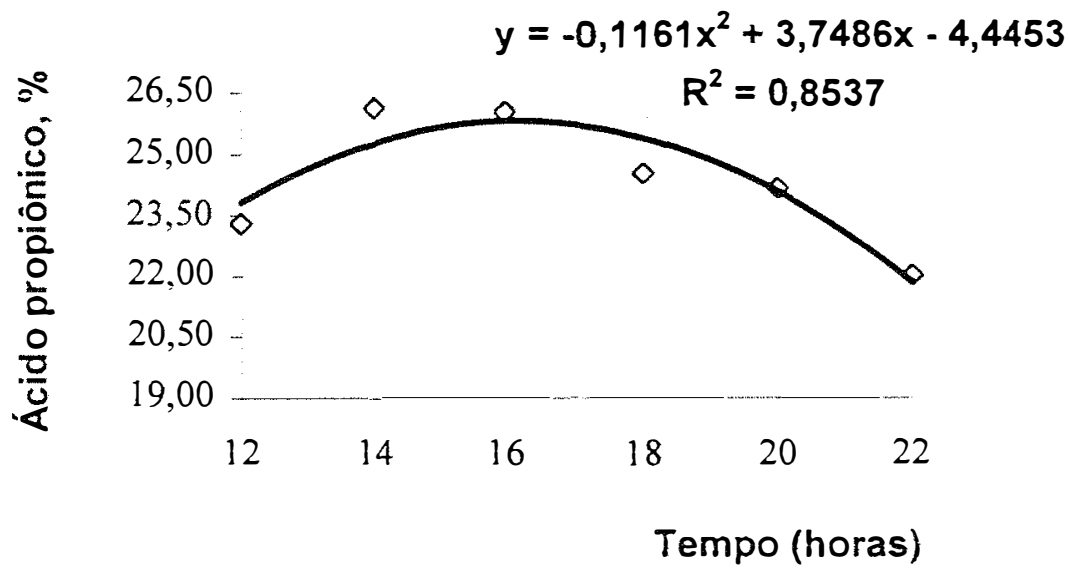

Figura 9. Equação de regressão ajustada em função dos tempos de amostragem para todas as dietas.

Os dados revelaram que o aumento na proporção de ácido propiônico foi provavelmente reflexo da grande quantidade de carboidratos solúveis presentes na cana-de-açúcar uma vez que os teores de uréia não alteraram sua proporção.

As proporções de ácido propiônico verificadas no presente experimento foram inferiores às observadas por Aroeira et al. (1993). Entretanto, as suplementaçōes utilizadas pelo autor, seja com $15 \%$ de farelo de algodão ou farelo de arroz induziram a aumentos nessas proporçōes em relação às aqui observadas. Manzano et al. (1983) utilizando teores de farelo de soja $(0,3 ;, 6$; 0,9 e $1,2 \mathrm{~kg}$ ) obtiveram proporçōes semelhantes (17 a $22 \%$ ) ao do presente experimento. 


\subsection{Relação ácido acético:propiônico}

$\mathrm{Na}$ Tabela 8 são exibidos os valores médios da relação ácido acético:propiônico. As Figuras 10 e 11 ilustram as equações de regressão ajustadas em função dos tempos de amostragem.

Não foram observadas diferenças $(P>0,05)$ entre os tratamentos para a relação ácido acético:propiônico entre 0-10 horas.

Quando analisados os dados entre os tempos de amostragem, verificouse efeito quadrático nessa relação. A menor taxa $(2,40)$ foi encontrada 5,95 horas após a alimentação dos animais.

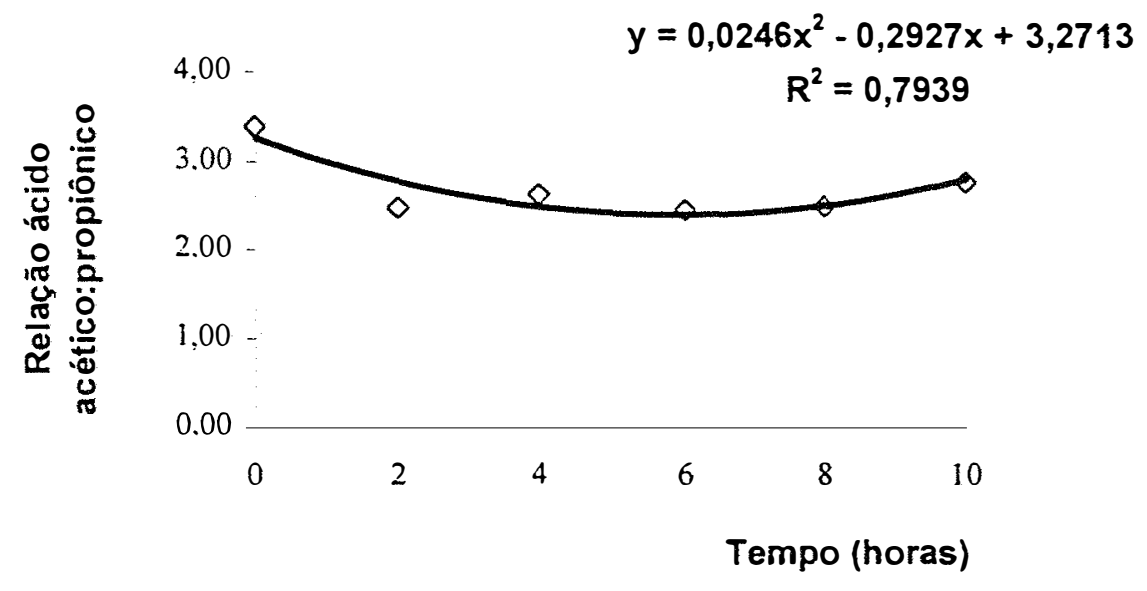

Figura 10. Equação de regressão ajustada em função dos tempos de amostragem para todas as dietas.

No período 12-22 horas foram constatadas diferenças $(P<0,05)$ entre os tratamentos para a relação ácido acético:propiônico. Os animais que receberam o tratamento $A(2,80)$ apresentaram maior relação ácido acético:propiônico que os animais submetidos ao tratamento $C(2,42)$. Os tratamentos $B(2,64)$ e $D$ $(2,67)$ não diferiram entre si e nem entre $A$ e $C$ para essa variável. 
Tabela 8. Valores médios da relação ácido acético:propiônico no fluido ruminal de acordo com as dietas experimentais e os tempos de amostragem.

\begin{tabular}{|c|c|c|c|c|c|c|c|c|c|}
\hline \multirow{2}{*}{\multicolumn{2}{|c|}{ Dietas }} & \multicolumn{6}{|c|}{ Tempo (horas) } & \multicolumn{2}{|c|}{ Efeito $^{1}$} \\
\hline & & 2 & 4 & 6 & 8 & 10 & Média & $\mathrm{L}$ & Q \\
\hline \multirow[t]{2}{*}{ A } & 3,59 & 2,50 & 2,76 & 2,68 & 2,76 & 3,04 & $2,88 \mathbf{a}$ & NS & $0,00001^{2}$ \\
\hline & $\pm 0,23^{*}$ & $\pm 0,58$ & $\pm 0,71$ & $\pm 0,52$ & $\pm 0,47$ & $\pm 0,35$ & $\pm 0,39$ & & \\
\hline B & $\begin{array}{r}3,27 \\
\pm 0,51\end{array}$ & $\begin{array}{r}2,28 \\
\pm 0,34\end{array}$ & $\begin{array}{r}2,50 \\
\pm 0,26\end{array}$ & $\begin{array}{r}2,35 \\
+0,22\end{array}$ & $\begin{array}{r}2,48 \\
\pm 0,26\end{array}$ & $\begin{array}{r}2,67 \\
\pm 0,15\end{array}$ & $\begin{aligned} & 2,59 \mathbf{a} \\
\pm & 0,36\end{aligned}$ & NS & $0,00001^{2}$ \\
\hline C & $\begin{array}{r}3,22 \\
\pm 0,19\end{array}$ & $\begin{array}{r}2,48 \\
\pm 0,31\end{array}$ & $\begin{array}{r}2,56 \\
\pm 0,20\end{array}$ & $\begin{array}{r}2,28 \\
\pm 0,30\end{array}$ & $\begin{array}{r}2,18 \\
\pm 0,19\end{array}$ & $\begin{array}{r}2,50 \\
\pm 0,09\end{array}$ & $\begin{aligned} & 2,54 \mathbf{a} \\
\pm & 0,36\end{aligned}$ & NS & $0,00001^{2}$ \\
\hline \multirow[t]{2}{*}{$\mathrm{D}$} & 3,54 & 2,67 & 2,75 & 2,51 & 2,58 & 2,85 & $2,82 \mathbf{a}$ & NS & $0,00001^{2}$ \\
\hline & $\pm 0,24$ & $\pm 0,40$ & $\pm 0,22$ & $\pm 0,19$ & $\pm 0,31$ & $\pm 0,31$ & $\pm 0,37$ & & \\
\hline
\end{tabular}

Dietas

\begin{tabular}{lllllllll}
\hline 12 & 14 & 16 & 18 & 20 & 22 & Média & L & Q
\end{tabular}

\begin{tabular}{lrrrrrrcll}
\hline A & 3,09 & 2,36 & 2,46 & 2,82 & 2,74 & 3,30 & $2,80 \mathbf{a}$ & NS & $0,00001^{3}$ \\
& $\pm 0,55$ & $\pm 0,39$ & $\pm 0,40$ & $\pm 0,53$ & $\pm 0,20$ & $\pm 0,49$ & $\pm 0,36$ & & \\
& & & & & & & & & \\
$\mathrm{~B}$ & 2,93 & 2,53 & 2,27 & 2,52 & 2,57 & 3,01 & $2,64 \mathbf{a b}$ & NS & $0,00001^{3}$ \\
& $\pm 0,40$ & $\pm 0,26$ & $\pm 0,10$ & $\pm 0,22$ & $\pm 0,25$ & $\pm 0,21 \pm 0,28$ & & \\
& & & & & & & & & \\
$\mathrm{C}$ & 2,92 & 2,30 & 2,16 & 2,26 & 2,29 & 2,58 & $2,42 \mathbf{b}$ & NS & $0,00001^{3}$ \\
& $\pm 0,19$ & $\pm 0,39$ & $\pm 0,36$ & $\pm 0,13$ & $\pm 0,21$ & $\pm 0,35$ & $\pm 0,28$ & & \\
& & & & & & & & & \\
$\mathrm{D}$ & 3,00 & 2,22 & 2,49 & 2,59 & 2,74 & 3,00 & $2,67 \mathbf{a b}$ & $\mathrm{NS}$ & $0,00001^{3}$ \\
& $\pm 0,52$ & $\pm 0,22$ & $\pm 0,16$ & $\pm 0,43$ & $\pm 0,12$ & $\pm 0,35 \pm 0,30$ & &
\end{tabular}

Médias seguidas por letras minúsculas distintas nas colunas, indicam diferenças significativas entre os tratamentos $(\mathrm{P}<0,05)$; ${ }^{1}$ Efeito: $\mathrm{L}=$ linear; $\mathrm{Q}=$ quadrático; $\mathrm{NS}=$ não significativo $(\mathrm{P}>0,05)$

* desvio padrão da média

$2 r^{2}=0,7938$

${ }^{3} \mathrm{r}^{2}=0,8355$ 
Quando analisados os dados entre os tempos de amostragem, verificouse efeito quadrático nessa relação para todos os tratamentos. A menor relação $(2,35)$ foi verificada às 16,91 horas.

A interação tratamento $x$ tempos de amostragem não foi significativa $(P>0,05)$. Os tratamentos foram igualmente influenciados pelos tempos de amostragem.

Os valores constatados para a relação ácido acético:propiônico foram reflexo da maior proporção de ácido propiônico em detrimento a proporção de ácido acético.

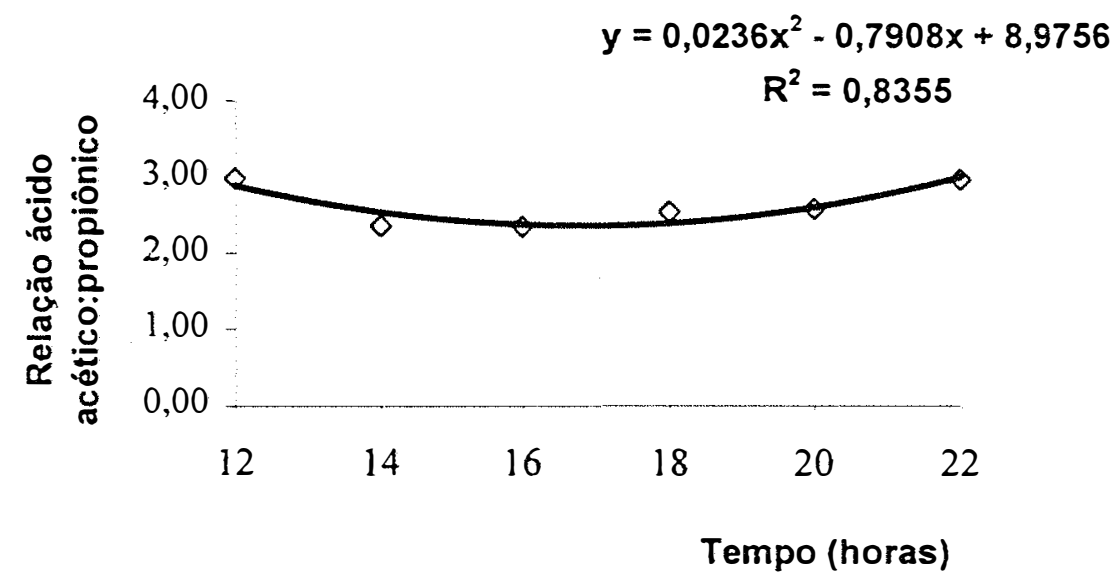

Figura 11. Equação de regressão ajustada em função dos tempos de amostragem para todas as dietas

\section{7 Ácido butírico}

Os valores médios da porcentagem de ácido butírico no fluido ruminal são demonstrados na Tabela 9 . A equações de regressão ajustadas em função dos tempos de amostragem são ilustrados pela Figura 12. 
Tabela 9. Valores médios da porcentagem de ácido butírico no fluido ruminal de acordo com as dietas experimentais e os tempos de amostragem.

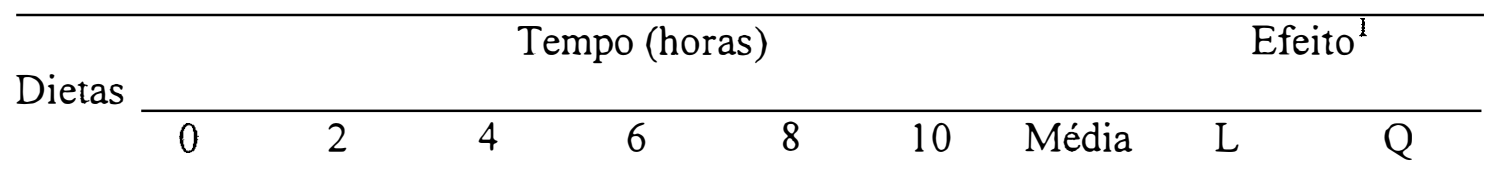

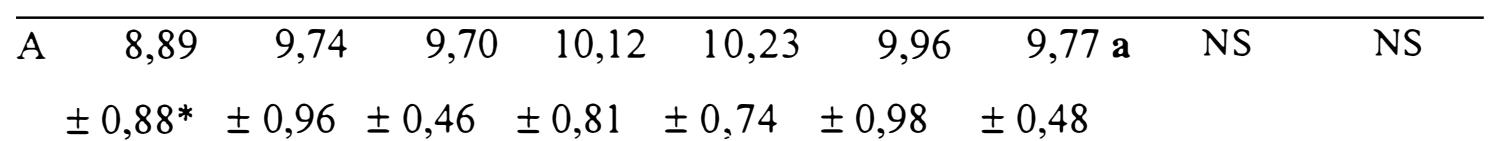

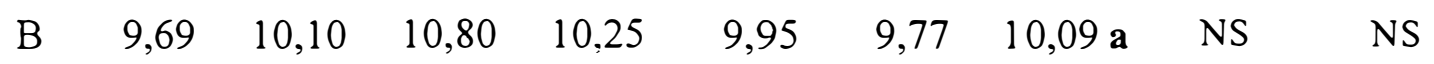
$\pm 3,23 \pm 5,09 \pm 3,99 \pm 3,34 \quad \pm 1,91 \quad \pm 2,62 \quad \pm 0,40$

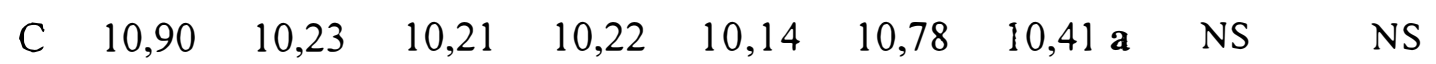
$\pm 2.25 \pm 0,50 \pm 0,56 \pm 1,63 \quad \pm 1,32 \pm 1,68 \pm 0,33$

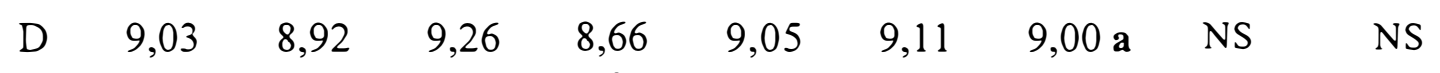
$\pm 1,86 \pm 2,36 \pm 2,12 \pm 1,97 \quad \pm 2,18 \quad \pm 1,72 \quad \pm 0,20$

Tempo (horas) $\quad$ Efeito $^{1}$

Dietas

Tempo (horas) $\quad$ Efeito $^{1}$

\begin{tabular}{rrrrrrrrrr} 
& 12 & 14 & 16 & 18 & 20 & 22 & Média & L & Q \\
& & & & & & & & & \\
\hline A & 9,19 & 9,94 & 10,46 & 10,34 & 10,27 & 10,18 & $10,06 \mathbf{a}$ & $0,00470^{2}$ & NS \\
& $\pm 0,73$ & $\pm 0,90$ & $\pm 1,05$ & $\pm 1,30$ & $\pm 1,03$ & $\pm 0,46$ & $\pm 0,46$ & & \\
& & & & & & & & & \\
B & 9,13 & 9,70 & 10,02 & 11,04 & 10,35 & 10,08 & $10,05 \mathbf{a}$ & $0,00470^{2}$ & NS \\
& $\pm 1,87$ & $\pm 0,94$ & $\pm 1,07$ & $\pm 1,34$ & $\pm 1,32$ & $\pm 1,07$ & $\pm 0,64$ & & \\
& & & & & & & & & \\
C & 10,37 & 10,13 & 10,48 & 10,66 & 10,87 & 10,62 & $10,52 \mathbf{a}$ & $0,00470^{2}$ & NS \\
& $\pm 1,70$ & $\pm 1,55$ & $\pm 1,40$ & $\pm 1,10$ & $\pm 0,70$ & $\pm 1,97$ & $\pm 0,26$ & & \\
& & & & & & & & & \\
D & 8,81 & 8,25 & 8,94 & 8,85 & 8,96 & 8,70 & $8,75 \mathbf{a}$ & $0,00470^{2}$ & NS \\
& $\pm 1,98$ & $\pm 1,98$ & $\pm 1,82$ & $\pm 1,61$ & $\pm 1,41$ & $\pm 1,32$ & $\pm 0,26$ & &
\end{tabular}

Médias seguidas por letras minúsculas distintas nas colunas, indicam diferenças significativas entre os tratamentos $(\mathrm{P}<0,05)$; 'Efeito: $\mathrm{L}=$ linear; $\mathrm{Q}=$ quadrático; $\mathrm{NS}=$ não significativo $(\mathrm{P}>0,05)$

* desvio padrão da média

${ }^{2} \mathrm{r}^{2}=0,5772$ 
Não foram encontradas diferenças $(P>0,05)$ na porcentagem de ácido butírico entre os tratamentos.

Quando avaliados os resultados entre os tempos de amostragem, constatou-se efeito linear $(P<0,05)$ para todos os tratamentos no periodo $12-22$

Os resultados da análise da variância não mostraram efeito $(P>0,05)$ para a interação tratamento $x$ tempos de amostragem. Para a porcentagem de ácido butírico no rúmen, os tempos de amostragem tiveram efeitos iguais sobre os tratamentos.

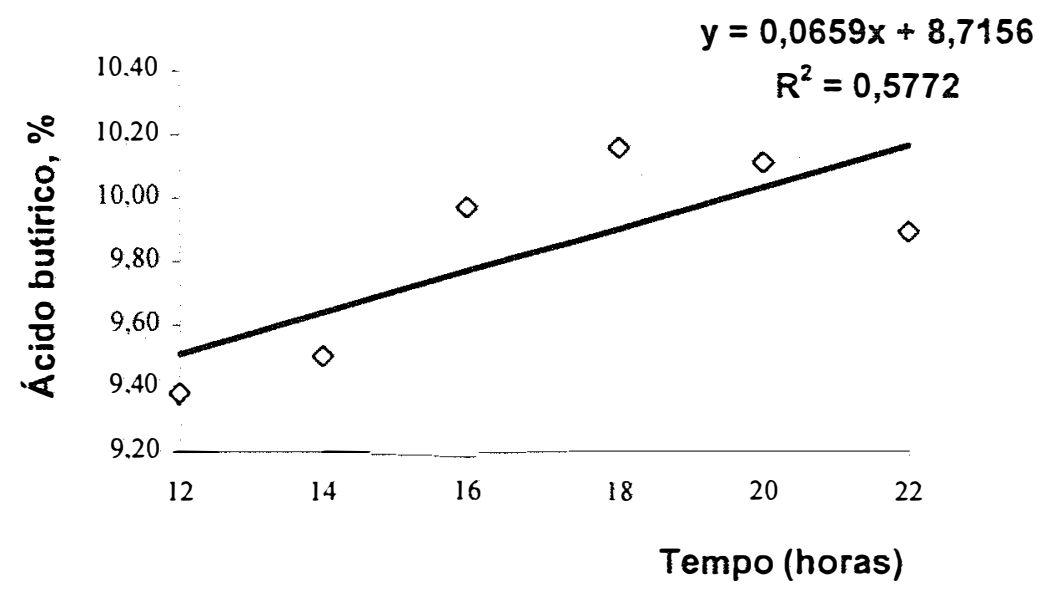

Figura 12. Equação de regressão ajustada em função dos tempos de amostragem para todas as dietas

Os valores observados para a porcentagem de ácido butírico permaneceram entre os valores $10-25 \%$ citados por Preston \& Leng (1981). Entretanto, foram inferiores aos verificados por Minor et al. (1977) que encontraram proporções de ácido butírico correspondente a $14 \%$ do total de AGV.

O resultado médio da porcentagem de ácido butírico $(9,83 \%)$ foi concordante com os dados de Valdez (1977); Ludovico \& Mattos (1997), porém, superior a obtida por Ferreiro et al. (1977) onde a porcentagem encontrada foi $8,15 \%$ para a cana-de-açúcar suplementada com $1 \%$ de uréia. 
Rodriguez et al (1993) não constataram diferenças na porcentagem de ácido butírico em função da adição de teores de uréia à cana-de-açúcar. As porcentagens médias encontradas pelos autores foram 12,99; 12,16 e 11,98\%, respectivamente para os teores 1,$0 ; 1,5$ e $2,0 \%$ de uréia.

\section{8 Ácido isobutírico}

$\mathrm{Na}$ Tabela 10 são apresentados os valores médios da porcentagem de ácido isobutírico no fluido ruminal. As Figuras 13 e 14 ilustram as equações de regressão ajustadas em função dos tempos de amostragem.

A porcentagem de ácido isobutírico não diferiu $(P>0,05)$ entre os tratamentos. Quando avaliados os resultados entre os tempos de amostragem, verificou-se que a porcentagem ácido isobutírico apresentou efeito linear $(P<0,05)$ em função dos tempos de amostragem no período 0-10 horas.

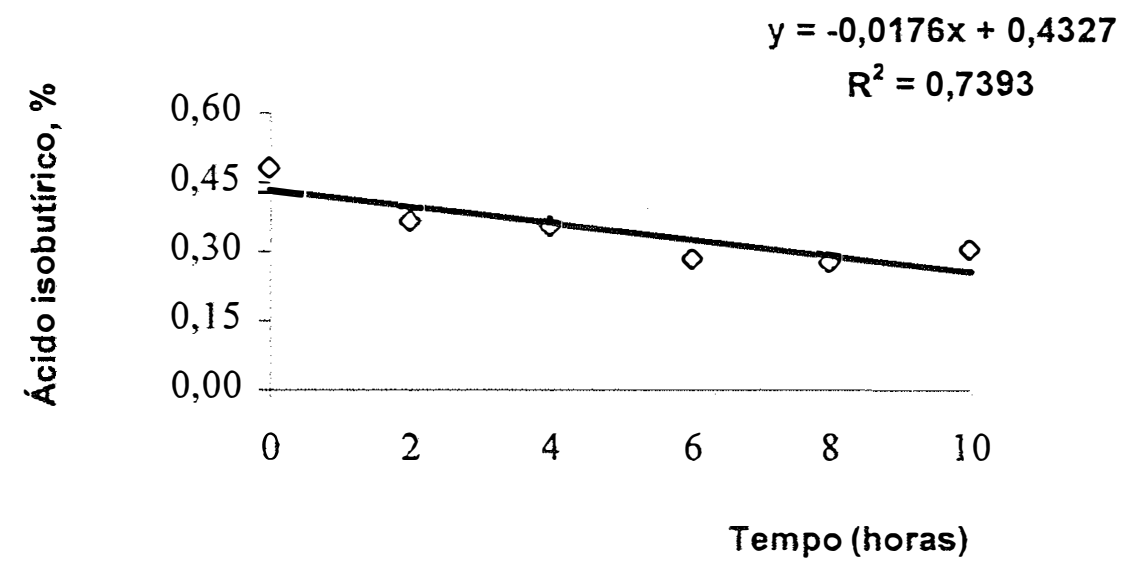

Figura 13. Equação de regressão ajustada em função dos tempos de amostragem para todas as dietas 
Tabela 10. Valores médios da porcentagem de ácido isobutírico no fluido ruminal de acordo com as dietas experimentais e os tempos de amostragem.

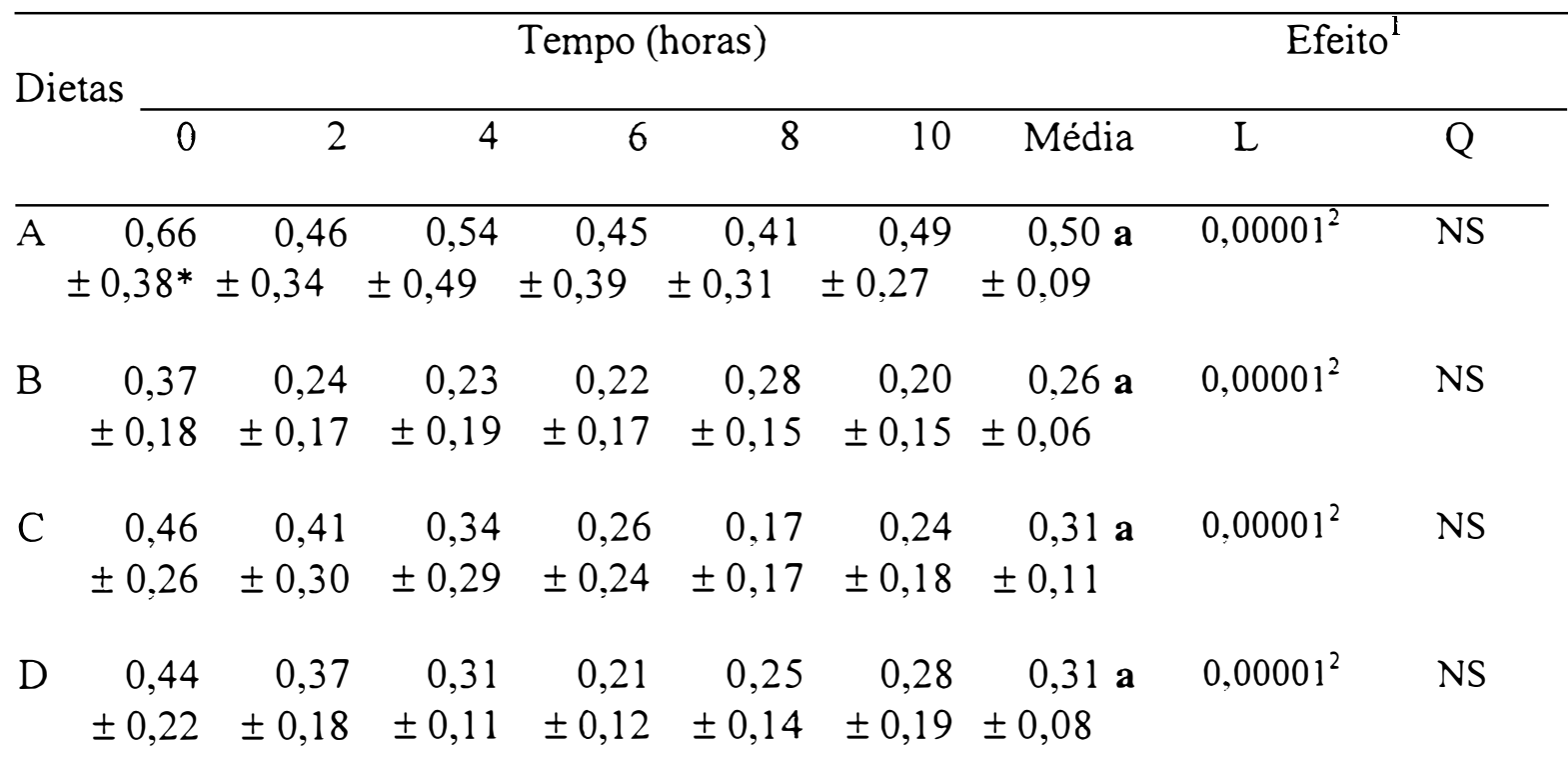

Tempo (horas)

Efeito ${ }^{1}$

Dietas

\begin{tabular}{lllllllll}
\hline 12 & 14 & 16 & 18 & 20 & 22 & Média & L & Q
\end{tabular}

\begin{tabular}{lrrrrrrcll}
\hline $\mathrm{A}$ & 0,59 & 0,44 & 0,41 & 0,40 & 0,41 & 0,54 & $0,46 \mathbf{a}$ & NS & $0,00016^{3}$ \\
& $\pm 0,35$ & $\pm 0,24$ & $\pm 0,29$ & $\pm 0,22$ & $\pm 0,18$ & $\pm 0,16$ & $\pm 0,08$ & & \\
$\mathrm{~B}$ & 0,19 & 0,18 & 0,14 & 0,20 & 0,19 & 0,27 & $0,19 \mathbf{a}$ & NS & $0,00016^{3}$ \\
& $\pm 0,08$ & $\pm 0,09$ & $\pm 0,07$ & $\pm 0,11$ & $\pm 0,14$ & $\pm 0,18$ & $\pm 0,04$ & & \\
& & & & & & & & & \\
$\mathrm{C}$ & 0,29 & 0,26 & 0,23 & 0,16 & 0,15 & 0,19 & $0,21 \mathbf{a}$ & NS & $0,00016^{3}$ \\
& $\pm 0,20$ & $\pm 0,20$ & $\pm 0,10$ & $\pm 0,10$ & $\pm 0,08$ & $\pm 0,09$ & $\pm 0,06$ & & \\
& & & & & & & & & \\
$\mathrm{D}$ & 0,32 & 0,29 & 0,20 & 0,19 & 0,17 & 0,21 & $0,23 \mathbf{a}$ & NS & $0,00016^{3}$ \\
& $\pm 0,19$ & $\pm 0,19$ & $\pm 0,11$ & $\pm 0,17$ & $\pm 0,09$ & $\pm 0,13$ & $\pm 0,06$ & &
\end{tabular}

Médias seguidas por letras minúsculas distintas nas colunas, indicam diferenças significativas entre os tratamentos $(\mathrm{P}<0,05){ }^{1}$ Efeito: $\mathrm{L}=$ linear; $\mathrm{Q}=$ quadrático; $N S=$ não significativo $(\mathrm{P}>0,05)$

* desvio padrão da média

$2 r^{2}=0,7391$

${ }^{3} \mathrm{r}^{2}=0,9448$ 
Entre 12-22 horas, verificou-se efeito quadrático $(P<0,05)$ e a menor porcentagem $(0,22 \%)$ foi detectada às 18 horas.

Não houve efeito $(P>0,05)$ para a interação tratamento $x$ tempos de amostragem. Os tempos de amostragem tiveram efeitos iguais $(P>0,05)$ sobre os tratamentos.

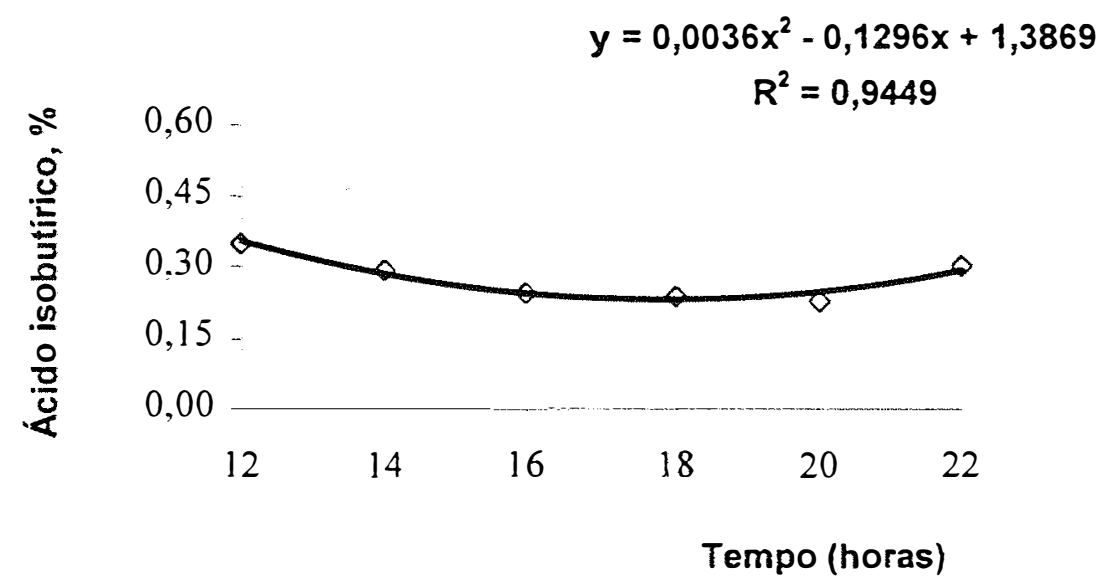

Figura 14. Equação de regressão ajustada em função dos tempos de amostragem para todas as dietas

\section{9 Ácido valérico}

Os valores médios da porcentagem de ácido valérico no fluido ruminal são exibidos na Tabela 11.

Não foram observadas diferenças $(P>0,05)$ na porcentagem de ácido valérico entre os tratamentos. Da mesma forma, não ocorreram diferenças $(P>0,05)$ dentro do mesmo tratamento nos diferentes tempos de amostragem.

Os resultados da análise da variância não mostraram efeito $(P>0,05)$ para a interação tratamento $x$ tempos de amostragem. Para a porcentagem de 
Tabela 11. Valores médios da porcentagem de ácido valérico no fluido ruminal de acordo com as dietas experimentais e os tempos de amostragem

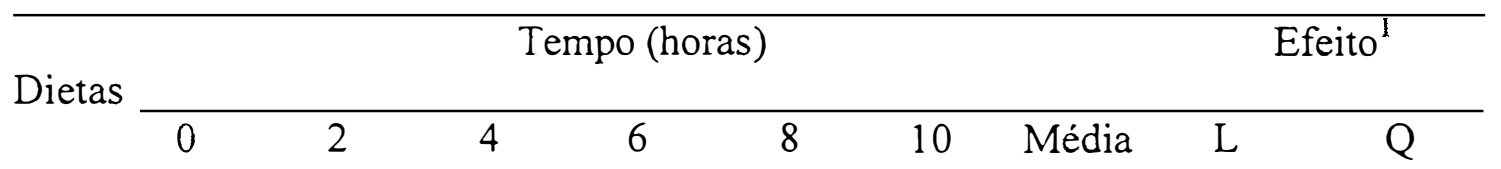

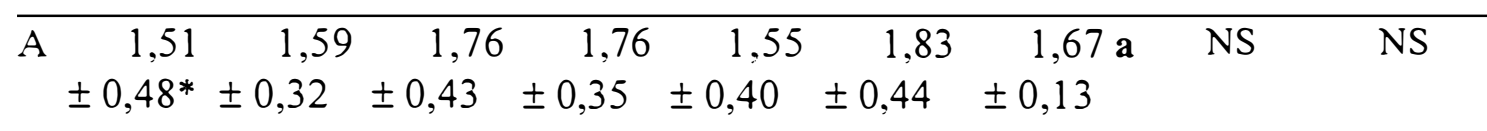

$\begin{array}{llllllllll}\text { B } & 2,86 & 1,54 & 2,36 & 2,29 & 3,04 & 2,20 & 2,38 \mathbf{a} & \text { NS } & \text { NS }\end{array}$ $\pm 1,39 \pm 0,90 \pm 1,01 \quad \pm 1,19 \pm 1,41 \quad \pm 1,38 \pm 0,53$

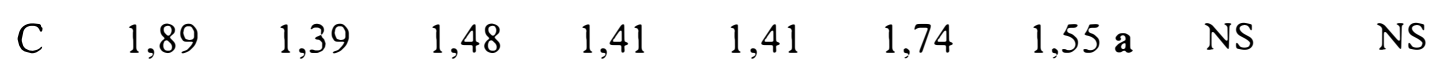
$\pm 1,55 \pm 0,77 \quad \pm 1,25 \quad \pm 0,87 \quad \pm 1,01 \quad \pm 0,76 \quad \pm 0,21$

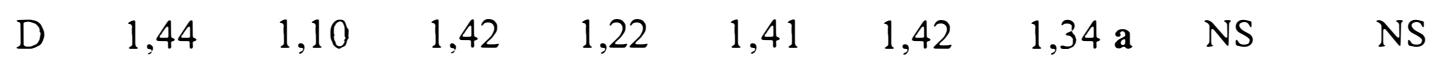
$\pm 0,90 \pm 0,35 \pm 1,11 \quad \pm 0,69 \quad \pm 0,96 \quad \pm 0,95 \quad \pm 0,14$

Tempo (horas) $\quad$ Efeito $^{1}$

Dietas

\begin{tabular}{lllllllll}
\hline 12 & 14 & 16 & 18 & 20 & 22 & Média & L & Q
\end{tabular}

\begin{tabular}{rrrrrrrrrr}
\hline A & 1,59 & 1,87 & 1,80 & 1,51 & 1,82 & 1,85 & 1,74 a & NS & NS \\
& $\pm 0,71$ & $\pm 0,68$ & $\pm 0,53$ & $\pm 0,42$ & $\pm 0,86$ & $\pm 0,98$ & $\pm 0,15$ & &
\end{tabular}
$\begin{array}{llllllllll}\text { B } & 2,22 & 1,67 & 1,85 & 2,29 & 1,55 & 1,65 & 1,87 \mathbf{a} & \text { NS } & \text { NS }\end{array}$ $\pm 1,03 \pm 0,75 \pm 1,18 \pm 1,30 \pm 0,82 \pm 1,06 \pm 0,31$

$\begin{array}{llllllllll}\text { C } & 1,43 & 1,61 & 1,72 & 1,30 & 2,12 & 1,81 & 1,66 \mathbf{a} & \text { NS } & \text { NS }\end{array}$ $\pm 0,76 \pm 0,61 \pm 0,56 \pm 0,59 \pm 0,95 \pm 0,88 \pm 0,29$

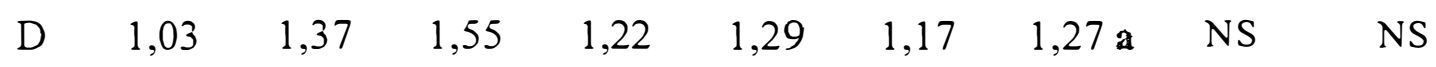
$\pm 0,30 \pm 0,89 \pm 0,91 \quad \pm 0,30 \pm 0,34 \quad \pm 0,33 \pm 0,18$

Médias seguidas por letras minúsculas distintas nas colunas, indicam diferenças significativas entre os tratamentos $(\mathrm{P}<0,05)$; 'Efeito: $\mathrm{L}=$ linear; $\mathrm{Q}=$ quadrático; $\mathrm{NS}=$ não significativo $(\mathrm{P}>0,05)$

* desvio padrão da média 
ácido valérico no rúmen, os tempos de amostragem tiveram efeitos iguais sobre os tratamentos.

\subsection{0 Ácido isovalérico}

A Tabela 12 apresenta os valores médios porcentagem de ácido isovalérico no fluido ruminal. A Figura 15 ilustra a equação de regressão ajustada em função dos tempos de amostragem.

Não foram observadas diferenças $(P>0,05)$ na porcentagem de ácido isovalérico entre os tratamentos. Quando avaliados os resultados entre os tempos de amostragem, constatou-se um efeito quadrático $(P<0,05)$ no periodo 0-10 horas, no qual a menor porcentagem de ácido isovalérico $(1,61 \%)$ foi observada 6,72 horas após o fornecimento da alimentação.

Os resultados da análise da variância não mostraram efeito $(P>0,05)$ para a interação tratamento $x$ tempos de amostragem.

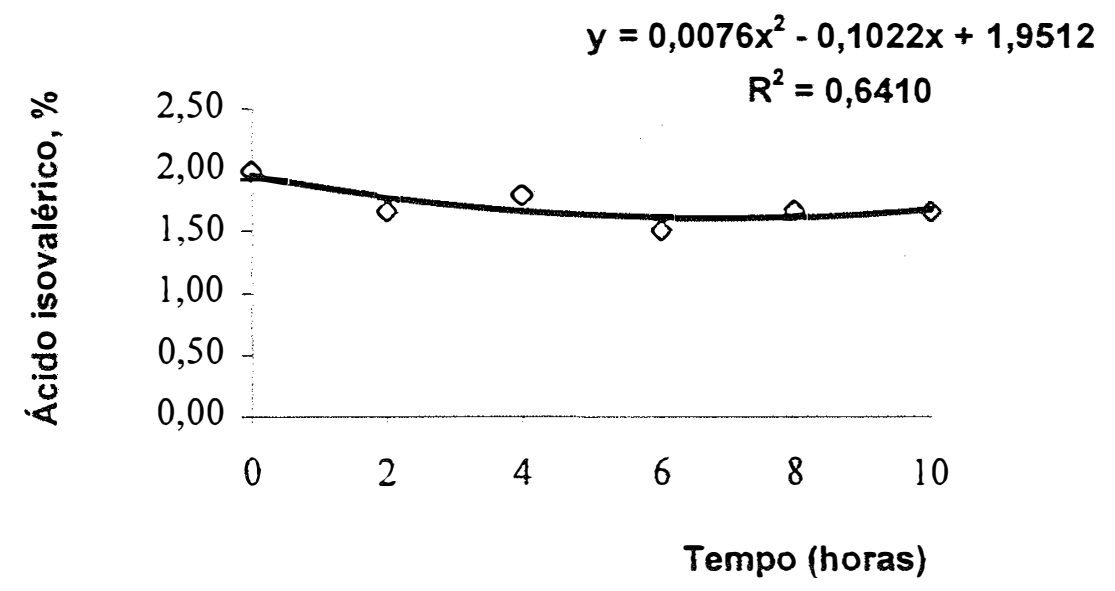

Figura 15. Equação de regressão ajustada em função dos tempos de amostragem para todos as dietas. 
Tabela 12. Valores médios da porcentagem de ácido isovalérico no fluido ruminal de acordo com as dietas experimentais e os tempos de amostragem.

\begin{tabular}{|c|c|c|c|c|c|c|c|c|c|}
\hline \multirow{2}{*}{ Dieta } & \multicolumn{7}{|c|}{ Tempo (horas) } & \multicolumn{2}{|c|}{ Efeito $^{1}$} \\
\hline & 0 & 2 & 4 & 6 & 8 & 10 & Média & $\mathrm{L}$ & Q \\
\hline A & $\begin{array}{r}1,97 \\
\pm 0,63\end{array}$ & $\begin{array}{r}1,71 \\
\pm 0,52\end{array}$ & $\begin{array}{r}1,72 \\
\pm 0,67\end{array}$ & $\begin{array}{r}1,54 \\
\pm 0,73\end{array}$ & $\begin{array}{r}1,52 \\
\pm 0,57\end{array}$ & $\begin{array}{r}1,56 \\
\pm 0,50\end{array}$ & $\begin{array}{r}1,67 \mathbf{a} \\
\pm 0,17\end{array}$ & NS & $0,03941^{2}$ \\
\hline B & $\begin{array}{r}2,26 \\
\pm 1,05\end{array}$ & $\begin{array}{r}1,59 \\
\pm 0,29\end{array}$ & $\begin{array}{r}2,26 \\
\pm 0,99\end{array}$ & $\begin{array}{r}1,75 \\
\pm 0,67\end{array}$ & $\begin{array}{r}2,32 \\
\pm 1,02\end{array}$ & $\begin{array}{r}1,93 \\
\pm 0,54\end{array}$ & $\begin{aligned} & 2,02 \mathbf{a} \\
\pm & 0,31\end{aligned}$ & NS & $0,03941^{2}$ \\
\hline $\mathrm{C}$ & $\begin{array}{r}1,89 \\
\pm 0,26\end{array}$ & $\begin{array}{r}1,69 \\
\pm 0,26\end{array}$ & $\begin{array}{r}1,42 \\
\pm 0,35\end{array}$ & $\begin{array}{r}1,30 \\
\pm 0,25\end{array}$ & $\begin{array}{r}1,38 \\
\pm 0,45\end{array}$ & $\begin{array}{r}1,64 \\
\pm 0,37\end{array}$ & $\begin{array}{l}1,55 \mathbf{a} \\
\pm 0,22\end{array}$ & NS & $0,03941^{2}$ \\
\hline D & $\begin{array}{r}1,83 \\
\pm 0,32\end{array}$ & $\begin{array}{r}1,68 \\
\pm 0,32\end{array}$ & $\begin{array}{r}1,82 \\
\pm 0,44\end{array}$ & $\begin{array}{r}1,45 \\
\pm 0,24\end{array}$ & $\begin{array}{r}1,47 \\
\pm 0,24\end{array}$ & $\begin{array}{r}1,56 \\
\pm 0,16\end{array}$ & $\begin{aligned} & 1,63 \mathbf{a} \\
\pm & 0,17\end{aligned}$ & NS & $0,03941^{2}$ \\
\hline \multirow{2}{*}{ Diet } & \multicolumn{7}{|c|}{ Tempo (horas) } & \multicolumn{2}{|c|}{ Efeito $^{1}$} \\
\hline & 12 & 14 & 16 & 18 & 20 & 22 & Média & $\mathrm{L}$ & $\bar{Q}$ \\
\hline A & $\begin{array}{r}1,80 \\
\pm 0,37\end{array}$ & $\begin{array}{r}1,56 \\
\pm 0,40\end{array}$ & $\begin{array}{r}1,51 \\
\pm 0,50\end{array}$ & $\begin{array}{r}1,43 \\
\pm 0,55\end{array}$ & $\begin{array}{r}1,65 \\
\pm 0,28\end{array}$ & $\begin{array}{r}1,64 \\
\pm 0,31\end{array}$ & $\begin{array}{l}1,60 \mathbf{a} \\
\pm 0,13\end{array}$ & NS & NS \\
\hline B & $\begin{array}{r}1,74 \\
\pm 0,23\end{array}$ & $\begin{array}{r}1,59 \\
\pm \\
0,28\end{array}$ & $\begin{array}{r}1,42 \\
\pm 0,09\end{array}$ & $\begin{array}{r}1,50 \\
\pm 0,14\end{array}$ & $\begin{array}{r}1,45 \\
\pm 0,15\end{array}$ & $\begin{array}{r}1,72 \\
\pm 0,27\end{array}$ & $\begin{aligned} & 1,57 \mathbf{a} \\
\pm & 0,14\end{aligned}$ & NS & NS \\
\hline C & $\begin{array}{r}1,68 \\
\pm 0,29\end{array}$ & $\begin{array}{r}2,30 \\
\pm 1,55\end{array}$ & $\begin{array}{r}1,40 \\
\pm 0,04\end{array}$ & $\begin{array}{r}1,34 \\
\pm 0,24\end{array}$ & $\begin{array}{r}2,35 \\
\pm 1,93\end{array}$ & $\begin{array}{r}1,41 \\
\pm 0,38\end{array}$ & $\begin{aligned} & 1,75 \mathbf{a} \\
\pm & 0,46\end{aligned}$ & NS & NS \\
\hline $\mathrm{D}$ & $\begin{array}{r}1,50 \\
\pm 0,22\end{array}$ & $\begin{array}{r}1,48 \\
\pm 0,17\end{array}$ & $\begin{array}{r}1,65 \\
\pm 0,35\end{array}$ & $\begin{array}{r}3,09 \\
\pm 2,99\end{array}$ & $\begin{array}{r}1,82 \\
\pm 0,51\end{array}$ & $\begin{array}{r}1,79 \\
\pm 0,49\end{array}$ & $\begin{aligned} & 1,89 \mathbf{a} \\
\pm & 0,61\end{aligned}$ & NS & NS \\
\hline
\end{tabular}

Médias seguidas por letras minúsculas distintas nas colunas, indicam diferenças significativas entre os tratamentos $(\mathrm{P}<0,05)$;Efeito: $\mathrm{L}=$ linear; $\mathrm{Q}=$ quadrático; $N S=$ não significativo $(\mathrm{P}>0,05)$

* desvio padrão da média

${ }^{2} \mathrm{r}^{2}=0,6411$ 
No levantamento bibliográfico não foram encontrados dados específicos referentes às porcentagens de ácido isobutírico, valérico e isovalérico em dietas com cana-de-açúcar.

Entretanto, nos estudos conduzidos por Song \& Kennelly (1990) que utilizaram teores de bicarbonato de amônio $\left(0 ; 95 ; 190\right.$ ou 280 g.dia $\left.^{-1}\right)$ através de infusão contínua via cânula ruminal observou-se que as proporções de ácido isobutírico e isovalérico foram diminuídas em função do aumento nos teores de bicarbonato de amônio. Tal comportamento não foi observado no presente experimento, uma vez que não foram observadas diferenças entre os tratamentos adotados para esse ácidos.

Os ácido isobutírico e isovalérico são derivados da fermentação das proteínas (aminoácidos) e são fatores de crescimento para algumas espécies de bactérias; entre elas as bactérias celulolíticas (Russel \& Hespell, 1981).

\subsection{Concentração de nitrogênio amoniacal $\left(\mathrm{N}-\mathrm{NH}_{3}\right)$}

Os valores médios da concentração de $\mathrm{N}^{-\mathrm{NH}_{3}}$ no fluido ruminal são apresentados na Tabela 13. As Figuras 16, 17 e 18 ilustram a equações de regressão ajustadas em função do tempos de amostragem.

Comparando-se a concentração ruminal de $\mathrm{N}-\mathrm{NH}_{3}$ constataram-se diferenças $(P<0,05)$ entre os tratamentos. Os animais que receberam o tratamento $D\left(16,52{\mathrm{mg} . \mathrm{dl}^{-1}}^{-1}\right)$ apresentaram maiores concentrações ruminais de $\mathrm{N}-\mathrm{NH}_{3}$ em relação aos animais que receberam os tratamentos $\mathrm{A}\left(8,10 \mathrm{mg}^{\mathrm{d}} \mathrm{l}^{-1}\right) \mathrm{e}$ $B\left(7,25 \mathrm{mg} \mathrm{dl} l^{-1}\right)$; porém, não apresentaram diferenças $(P>0,05)$ aos animais submetidos ao tratamento $C\left(13,65 \mathrm{mg} \mathrm{dl}^{-1}\right)$. Tal comportamento foi observado em ambos periodos (0-10 horas e 12-22 horas). 
Tabela 13. Valores médios da concentração $\mathrm{N}-\mathrm{NH}_{3}\left(\mathrm{mg} \mathrm{dl}^{-1}\right)$ no fluido ruminal de acordo com as dietas experimentais e os tempos de amostragem.

\begin{tabular}{|c|c|c|c|c|c|c|c|c|c|}
\hline \multirow{2}{*}{\multicolumn{2}{|c|}{ Dietas }} & \multicolumn{6}{|c|}{ Tempo (horas) } & \multicolumn{2}{|c|}{ Efeito $^{1}$} \\
\hline & & & & 6 & 0 & 10 & Módi & $T$ & $\Omega$ \\
\hline & 768 & 11.38 & 7.11 & 818 & 8.61 & 6.38 & $22 \mathrm{~b}$ & NS & NS \\
\hline & $\pm 3,55$ & $\pm 2,89$ & $\pm 3,33$ & $\pm 4,04$ & $\pm 2,55$ & \pm 1.29 & $\pm 1,73$ & & \\
\hline & 4,03 & 12,88 & 6,08 & 9,79 & 7,41 & 5,04 & $7,54 \mathbf{b}$ & NS & NS \\
\hline & $\pm 1,86$ & $\pm 6,65$ & $\pm 2,84$ & $\pm 7,38$ & $\pm 5,27$ & $\pm 2,00$ & $\pm 3,01$ & & \\
\hline & $\begin{array}{r}4,87 \\
+086\end{array}$ & 19,13 & 16,31 & 20,78 & 23,00 & 9,97 & $15,67 \mathbf{a b}$ & NS & $0,00001^{2}$ \\
\hline & $\begin{array}{r}9,89 \\
+2,90\end{array}$ & $\begin{array}{r}21,18 \\
\pm 8,93\end{array}$ & $\begin{array}{r}17,63 \\
\pm 6,05\end{array}$ & $\begin{array}{r}22,33 \\
10.23\end{array}$ & $\begin{array}{r}19,62 \\
\pm 10,70\end{array}$ & $\begin{array}{r}16,73 \\
+10,71\end{array}$ & $\begin{array}{r}17,89 \text { a } \\
\pm\end{array}$ & NS & $0,00127^{3}$ \\
\hline
\end{tabular}

Tempo (horas) $\quad$ Efeito $^{1}$

Dietas

\begin{tabular}{rrrrrrrccc} 
& 12 & 14 & 16 & 18 & 20 & 22 & Média & $\mathrm{L}$ & $\mathrm{Q}$ \\
\hline $\mathrm{A}$ & 7,80 & 9,82 & 8,94 & 7,54 & 7,23 & 6,52 & $7,98 \mathbf{b}$ & $\mathrm{NS}$ & $0,00020^{4}$ \\
& $\pm 2,12$ & $\pm 2,08$ & $\pm 1,57$ & $\pm 1,57$ & $\pm 1,88$ & $\pm 1,62$ & $\pm 1,20$ & & \\
$\mathrm{~B}$ & 3,86 & 8,78 & 10,39 & 7,19 & 6,12 & 5,33 & $6,95 \mathbf{b}$ & $\mathrm{NS}$ & $0,00020^{4}$ \\
& $\pm 1,77$ & $\pm 4,43$ & $\pm 4,76$ & $\pm 5,52$ & $\pm 2,29$ & $\pm 2,86$ & $\pm 2,37$ & & \\
$\mathrm{C}$ & 5,21 & 14,90 & 16,15 & 13,55 & 13,86 & 6,07 & $11,62 \mathbf{a b}$ & $\mathrm{NS}$ & $0,00020^{4}$ \\
& $\pm 3,54$ & $\pm 7,44$ & $\pm 7,38$ & $\pm 6,51$ & $\pm 8,30$ & $\pm 2,05 \pm 4,73$ & & \\
& & & & & & & & & \\
$\mathrm{D}$ & 12,69 & 13,75 & 16,19 & 18,43 & 15,68 & 14,14 & $15,15 \mathbf{a}$ & $\mathrm{NS}$ & $0,00020^{4}$ \\
& $\pm 4,48$ & $\pm 7,14$ & $\pm 12,29$ & $\pm 9,00$ & $\pm 4,76$ & $\pm 9,33 \pm 2,06$ & &
\end{tabular}

Médias seguidas por letras minúsculas distintas nas colunas, indicam diferenças significativas entre os tratamentos $(\mathrm{P}<0,05)$; 'Efeito: $\mathrm{L}=$ linear; $\mathrm{Q}=$ quadrático; $\mathrm{NS}=$ não significativo $(\mathrm{P}>0,05)$

* desvio padrão da média

${ }^{2} \mathrm{r}^{2}=0,7694$

${ }^{3} \mathrm{r}^{2}=0,7178$

${ }^{4} \mathrm{r}^{2}=0,7234$ 
Em relação aos tempos de amostragem, observou-se efeito quadrático $(P<0,05)$ para os tratamentos $C$ e $D$ no período 0-10 horas. Assim, para o tratamento $\mathrm{C}$, a maior concentração de $\mathrm{N}-\mathrm{NH}_{3}$ foi observada 5,57 horas após a

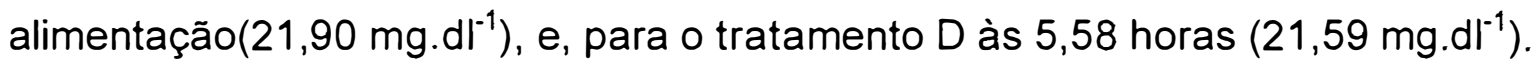

$A$ interação tratamento $x$ tempos de amostragem foi significativa $(P<0,05)$. Os tempos de amostragem tiveram efeitos diferentes sobre os tratamentos.

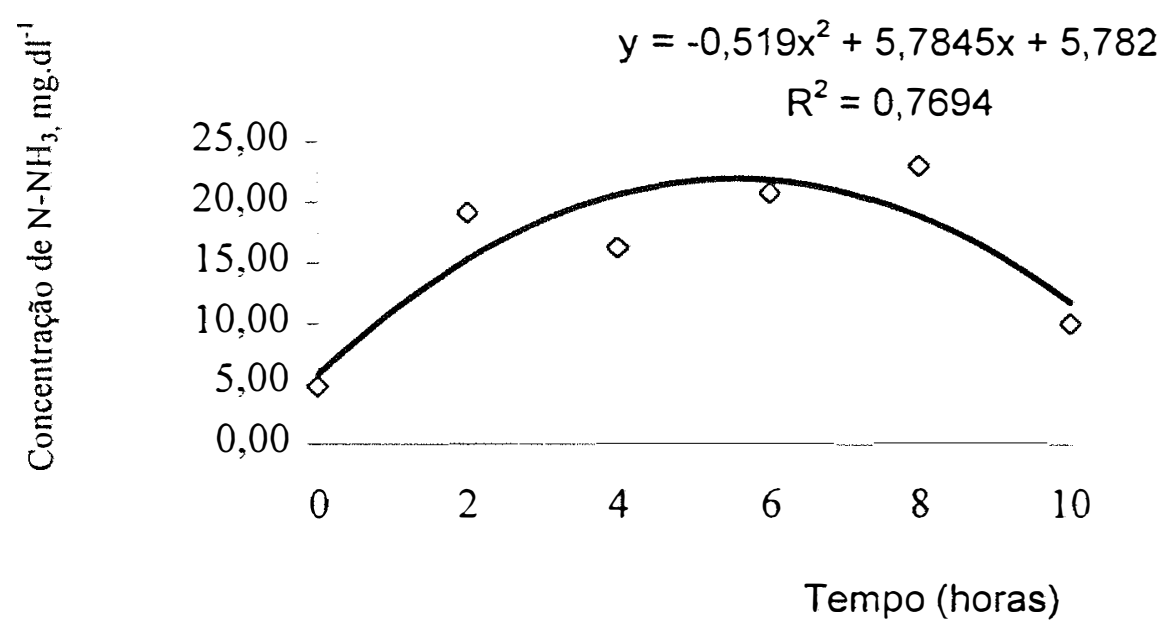

Figura 16. Equação de regressão ajustada em função dos tempos de amostragem para a dieta $\mathrm{C}$.

Para o intervalo de tempo 12-22 horas, verificou-se efeito quadrático $(\mathrm{P}<0,05)$ para todos os tratamentos. A maior concentração de $\mathrm{N}-\mathrm{NH}_{3}(13,28$ $\mathrm{mg} \cdot \mathrm{dl}^{-1}$ ) foi observada às 16,70 horas.

A interação tratamento $x$ tempos de amostragem não foi significativa $(P>0,05)$. Os tratamentos foram igualmente influenciados pelos diferentes tempos de amostragem. 


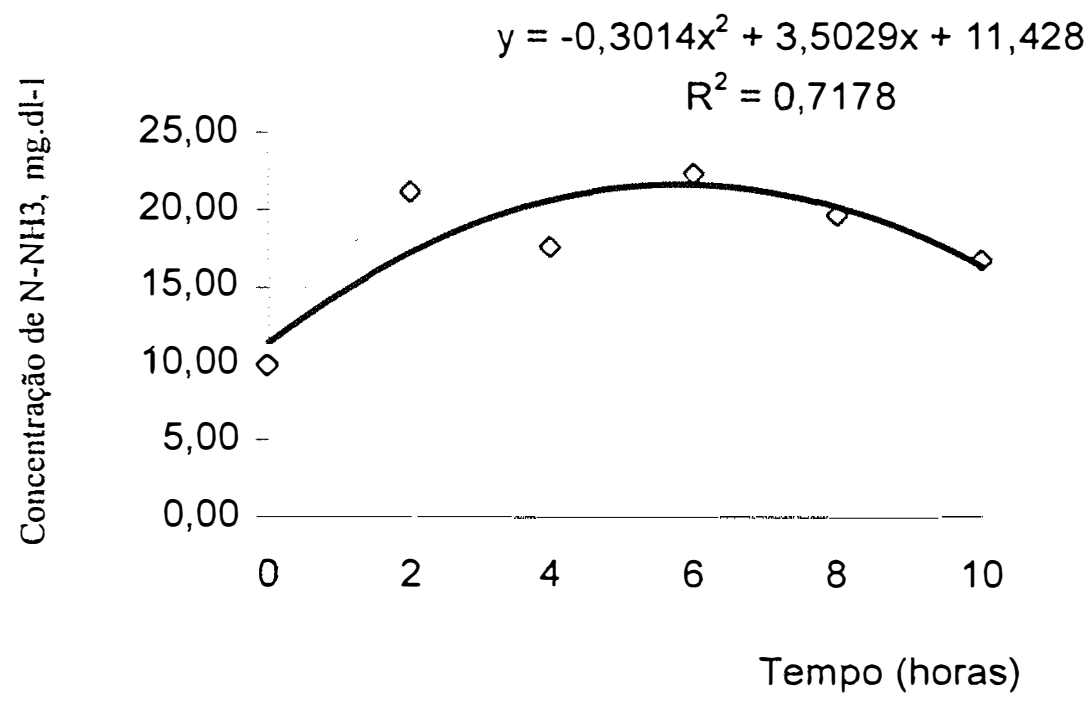

Figura 17. Equação de regressão ajustada em função dos tempos de amostragem para a dieta $D$

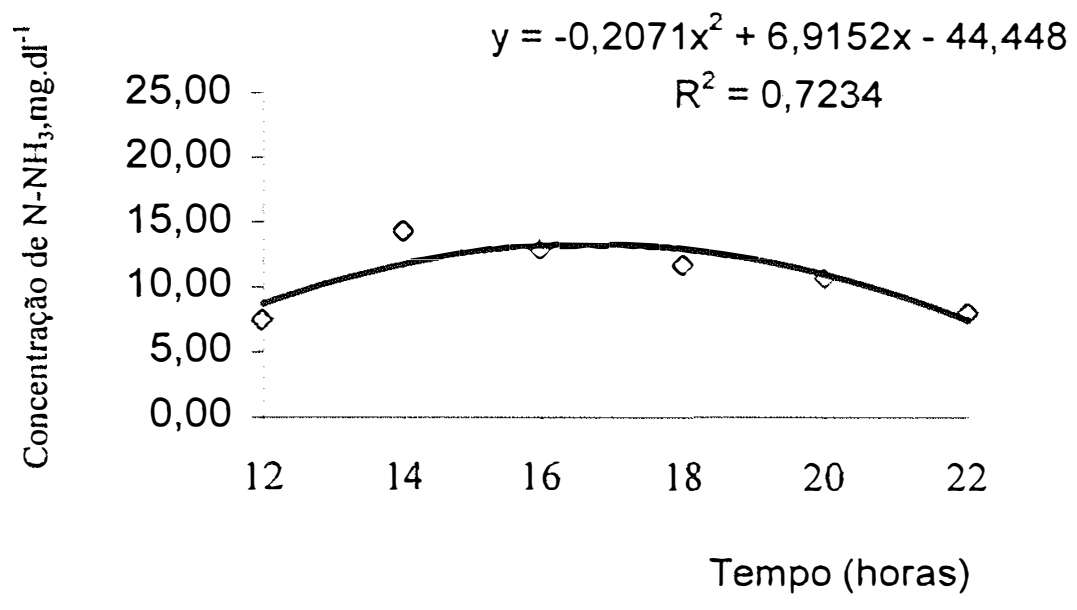

Figura 18. Equação de regressão ajustada em função dos tempos de amostragem para todas as dietas. 
As alterações verificadas nas concentrações médias de $\mathrm{N}-\mathrm{NH}_{3}$ entre os tratamentos foram reflexo da adição dos teores de uréia à ração. A elevação do teor protéico das dietas com uma fonte de nitrogênio prontamente disponível (uréia) favoreceu rápido aumento na concentração $\mathrm{N}-\mathrm{NH}_{3}$ ruminal duas horas após a alimentação. Entretanto, a ocorrência de "pico" de concentração em horários variados para os tratamentos adotados pode estar associado à freqüência de alimentação dos animais.

As concentrações médias de $\mathrm{N}-\mathrm{NH}_{3}$ observadas no fluido ruminal situaram-se durante a maior parte do tempo acima das mínimas necessárias (5 mg. $\mathrm{dl}^{-1}$ ) para a taxa máxima de crescimento microbiano obtida "in vitro" por Satter \& Slyter (1974). Entretanto, permaneceram abaixo da preconizada por Mehrez (1977), segundo o qual a concentração ótima de $\mathrm{N}-\mathrm{NH}_{3}$ no fluido ruminal corresponde a $23 \mathrm{mg} \mathrm{dl}^{-1} \mathrm{de}$ fluido ruminal.

No presente experimento, concentrações de $\mathrm{N}-\mathrm{NH}_{3}$ inferiores a $5 \mathrm{mg}^{-1} \mathrm{dl}^{-1}$ foram determinadas nos tempos de amostragem que precederam a alimentação ( 0 e 12 horas), evidenciando, assim, as variações na concentração de $\mathrm{N}-\mathrm{NH}_{3}$ ruminal ao longo das 24 horas, sendo que em alguns momentos ocorreram pontos ótimos para o crescimento microbiano; e em outros, esse fora limitado pelo déficit de $\mathrm{N}-\mathrm{NH}_{3}$ (Davidovich et al. 1977).

Manzano et al. (1983) não observaram diferenças nos valores de $\mathrm{N}-\mathrm{NH}_{3}$ que pudessem ser atribuídas ao efeito dos teores de farelo de soja. Os valores médios de $\mathrm{N}-\mathrm{NH}_{3}$ encontrados para os tempos de amostragem considerados $(0$, 2,4 e 6 horas após a alimentação) foram, respectivamente, 6,$78 ; 25,19 ; 8,75$ e $5,17 \mathrm{mg} \cdot \mathrm{dl}^{-1}$.

O efeito de teores de uréia (1,0; 1,5 e 2,0\%) sobre as concentrações de $\mathrm{N}$ $\mathrm{NH}_{3}$ no fluido ruminal foi verificado por Rodriguez et al. (1993). Os valores médios de $\mathrm{N}-\mathrm{NH}_{3}$ encontrados pelos autores foram respectivamente 25,$21 ; 34,93$ e 46,05 mg.dl-1; resultados esses, superiores aos observados no presente experimento. 


\subsection{Concentração de uréia plasmática}

Na Tabela 14 são demonstrados os valores médios da concentração de uréia plasmática.

Comparando-se as concentrações plasmáticas de uréia verificou-se diferenças $(P<0,05)$ entre os tratamentos.

Para o periodo de 0 a 10 horas observou-se que os tratamentos $C(36,54$ $\left.\mathrm{mg} \cdot \mathrm{dl}^{-1}\right)$ e $\mathrm{D}\left(42,04 \mathrm{mg} \cdot \mathrm{dl}^{-1}\right)$ não diferiram entre si, porém foram superiores aos tratamentos $A\left(18,25 \mathrm{mg}^{-\mathrm{dl}^{-1}}\right)$ e $\mathrm{B}\left(24,88 \mathrm{mg}^{\mathrm{dg}} \mathrm{dl}^{-1}\right)$.

No intervalo de 12 a 22 horas constatou-se que os animais que receberam o tratamento $D\left(43,54 \mathrm{mg} \mathrm{dl}^{-1}\right)$ apresentaram concentração de uréia plasmática superior aos que receberam os tratamentos $A\left(19,21 \mathrm{mg}^{-1} \mathrm{dl}^{-1}\right)$ e $B$ $\left(25,38 \mathrm{mg} \cdot \mathrm{dl}^{-1}\right)$. Os animais submetidos ao tratamento $\mathrm{C}\left(34,58 \mathrm{mg}^{-\mathrm{dl}^{-1}}\right)$ apresentaram concentrações de uréia plasmática maior que os que receberam o tratamento A.

Não ocorreram diferenças $(P>0,05)$ dentro do mesmo tratamento nos diferentes tempos de amostragem.

Os resultados da análise da variância não mostraram efeito $(P>0,05)$ para a interação tratamento $x$ tempos de amostragem. Para a concentração de uréia plasmática os tempos de amostragem tiveram efeitos iguais sobre os tratamentos.

De maneira semelhante ao constatado para a concentração de $\mathrm{N}_{-} \mathrm{NH}_{3}$ no rúmen, as alterações verificadas nas concentrações de uréia plasmática foram reflexo da adição dos teores crescente de uréia à ração.

Ao contrário do observado no presente experimento, Manzano et al. (1983) não encontraram diferenças nas concentrações de uréia plasmática em função do teor protéico das dietas. As concentrações médias obtidas foram 19,$0 ; 22,5 ; 23,5$ e $26,5 \mathrm{mg}^{-\mathrm{dl}^{-1}}$.

Miranda et al. (1998) determinaram os teores de uréia plasmática em novilhas alimentadas com diferentes fontes de NNP. As concentrações médias 
Tabela 14. Valores médios concentração de uréia plasmática $\left(m g . \mathrm{dl}^{-1}\right)$ de acordo com as dietas experimentais e os tempos de amostragem.

\begin{tabular}{|c|c|c|c|c|c|c|c|c|c|}
\hline \multirow{2}{*}{\multicolumn{2}{|c|}{ Dietas }} & \multicolumn{6}{|c|}{ Tempo (horas) } & \multicolumn{2}{|c|}{ Efeito } \\
\hline & & 2 & 4 & 6 & 8 & 10 & Média & $\mathrm{L}$ & $\mathrm{Q}$ \\
\hline $\bar{A}$ & $\begin{array}{r}17,00 \\
\pm 4,97\end{array}$ & $\begin{array}{r}18,00 \\
\pm 5,03\end{array}$ & $\begin{array}{r}19,50 \\
\pm 8,89\end{array}$ & $\begin{array}{r}19,50 \\
\pm 7,23\end{array}$ & $\begin{array}{r}17,50 \\
\pm 9,04\end{array}$ & $\begin{array}{r}18,00 \\
\pm 9,87\end{array}$ & $\begin{array}{r}18,25 \mathbf{b} \\
\pm 1,04\end{array}$ & NS & NS \\
\hline B & $\begin{array}{r}20,75 \\
\pm 5,56\end{array}$ & $\begin{array}{r}27,25 \\
\pm 6,85\end{array}$ & $\begin{array}{r}29,50 \\
\pm 8,81\end{array}$ & $\begin{array}{r}24,75 \\
\pm 5,44\end{array}$ & $\begin{array}{r}24,25 \\
\pm 4,65\end{array}$ & $\begin{array}{r}22,75 \\
\pm 5,50\end{array}$ & $\begin{array}{r}24,88 \mathbf{b} \\
\pm 3,13\end{array}$ & NS & NS \\
\hline C & $\begin{array}{r}31,00 \\
\pm 11,40\end{array}$ & $\begin{array}{r}38,00 \\
\pm 13,78\end{array}$ & $\begin{array}{r}38,50 \\
\pm 10,66\end{array}$ & $\begin{array}{r}33,75 \\
\pm 11,62\end{array}$ & $\begin{array}{r}40,25 \\
\pm 9,78\end{array}$ & $\begin{array}{r}37,75 \\
\pm 16,21\end{array}$ & $\begin{array}{c}36,54 \mathbf{a} \\
\pm 3,45\end{array}$ & NS & NS \\
\hline $\mathrm{D}$ & $\begin{array}{r}38,50 \\
\pm 8,35\end{array}$ & $\begin{array}{r}45,25 \\
+13,89\end{array}$ & $\begin{array}{r}41,00 \\
+13,09\end{array}$ & $\begin{array}{r}40,50 \\
+12,12\end{array}$ & $\begin{array}{r}47,25 \\
+16,01\end{array}$ & $\begin{array}{r}39,75 \\
\pm 8,66\end{array}$ & $\begin{array}{r}42,04 \mathbf{a} \\
\pm 3,43\end{array}$ & NS & NS \\
\hline
\end{tabular}

Dietas

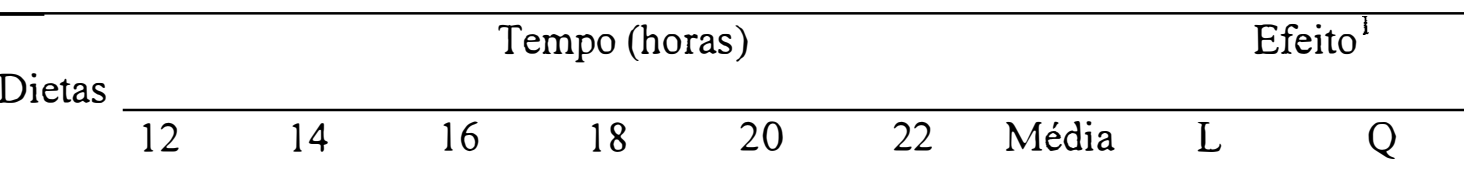

\begin{tabular}{rrrrrrrrrr}
\hline A & 18,00 & 19,75 & 18,50 & 19,75 & 20,25 & 19,00 & $19,21 \mathbf{c}$ & NS & NS \\
& $\pm 8,29$ & $\pm 9,46$ & $\pm 9,18$ & $\pm 12,26$ & $\pm 14,17$ & $\pm 11,40$ & $\pm 0,86$ & & \\
& & & & & & & & & \\
B & 22,75 & 28,75 & 26,00 & 25,00 & 26,00 & 23,75 & 25,38 bc & NS & NS \\
& $\pm 2,99$ & $\pm 9,81$ & $\pm 5,03$ & $\pm 5,10$ & $\pm 7,44$ & $\pm 1,89 \pm 2,09$ & & \\
& & & & & & & & & \\
C & 35,00 & 30,50 & 32,25 & 34,25 & 37,75 & 37,75 & 34,58 ab & NS & NS \\
& $\pm 8,04$ & $\pm 4,80$ & $\pm 5,62$ & $\pm 8,26$ & $\pm 8,50$ & $\pm 13,96 \pm 2,91$ & & \\
& & & & & & & & & \\
D & 38,00 & 43,25 & 49,00 & 40,75 & 45,50 & 44,75 & $43,54 \mathbf{a}$ & NS & NS \\
& $\pm 7,44$ & $\pm 7,14$ & $\pm 7,70$ & $\pm 7,03$ & $\pm 7,72$ & $\pm 6,40$ & $\pm 3,84$ & &
\end{tabular}

Médias seguidas por letras minúsculas distintas nas colunas, indicam diferenças significativas entre os tratamentos $(P<0,05) ;{ }^{1}$ Efeito: $L=$ linear; $Q=$ quadrático; $N S=$ não significativo $(P>0,05)$ 
de uréia plasmática não diferiram entre os tratamentos; e o pico ocorreu com $17,11 \mathrm{mg} \cdot \mathrm{dl}^{-1}$ às 5,93 horas após a alimentação.

Resultados semelhantes aos aqui verificados foram encontrados por Rodrigues (1985) em dietas com cana-de-açúcar. As concentrações obtidas foram 32,55 e $46,33 \mathrm{mg}_{\mathrm{dl}}{ }^{-1}$, respectivamente para os tratamentos com 1,0 e $1,5 \%$ de uréia.

Os valores encontrados no presente experimento situaram-se dentro da faixa de normalidade (17 a $53 \mathrm{mg}_{\mathrm{dl}}{ }^{-1}$ ) considerada para a variável em questão (Talk \& Schubert, 1965). 


\section{CONCLUSÕES}

A utilização de farelo de soja proporcionou maior consumo de matéria seca quando comparado com os teores de uréia empregados.

A adição de uréia à cana-de-açúcar alterou os valores de $\mathrm{pH}$, a relação ácido acético:propiônico, e as concentrações de $\mathrm{N}-\mathrm{NH}_{3}$, e uréia plasmática.

Com exceção do ácido valérico e das concentrações de uréia plasmática, as demais variáveis analisadas apresentaram variações em função dos tempos de amostragem. 


\section{REFERÊNCIAS BIBLIOGRÁFICAS}

ALVAREZ, F.J.; PRESTON, T. R. Studies on urea utilization on sugar cane diets: effect of level. Tropical Animal Production, v.1, n.3, p.194-207, 1976

AROEIRA, L. J. M., SILVEIRA, M. I.; LIZIERE, R. S., MATOS, L. L. Digestibilidade, balanço de nitrogênio e concentração de amônia no rúmen de novilhos mestiços alimentados com cana-de-açúcar e uréia mais farelos de arroz ou de algodão. Revista da Sociedade Brasileira de Zootecnia, v. 22, n.6, p. 893-901, 1993.

AROEIRA, L. J. M., LOPEZ, F. C. F., ; DAYRELL, M. S.; LIZIERE, R. S., TORRES, M. P. Digestibilidade, degradabilidade e taxa de passagem da cana-de-açúcar mais uréia e farelo de algodão em vacas mestiças holandês x zebu em lactação. Revista da Sociedade Brasileira de Zootecnia, v. 24, n.6, p. 1016-1026, 1995.

ASSOCIATION OF OFFICIAL ANALYTICAL CHEMISTS. Official Methods of Analysis. 12. Ed., Washinton, D.C., 1990.

BARTLEY,E. E.; DAVIDOVICH, A . D.; BARR, G. W.; GRIFFEL, G. W. et al. Ammonia toxicity in cattle. 1. Rumen and blood changes associated with toxicity and treatment methods. Journal of Animal Science, v.43, n.4, p. 835-841, 1976. 
BERGMAN, E. N. Energy contribuitions of volatile fatty acids from the gastrointestinal tract in various species. Physiological reviews., v.70, n.2, p.567-590, 1990.

BOIN, C. Efeitos desfavoráveis da utilização da uréia. In: SIMPÓSIO SOBRE NUTRIÇÃO DE BOVINOS, 2, Piracicaba, 1984. Uréia para ruminantes. Piracicaba:FEALQ, 1984, p.25-79.

BOIN, C. Cana-de-açúcar na alimentação de ruminantes. In: D’Arce, R. D.; Boin, C. e Mattos, W. R. S. (Ed.) Utilização de resíduos da agroindústria da cana-de-açúcar na alimentação de ruminantes. Piracicaba:FEALQ, 1985. p. $19-52$

BOIN,C. Cana-de-açúcar na alimentação de ruminantes. In: CONGRESSO PAULISTA DE AGRONOMIA, 6, Piracicaba, 1987.

BOIN,C.; TEDESCHI, L. O Cana-de-açúcar na alimentação de gado de corte. In: SIMPÓSIO SOBRE NUTRIÇÃO DE BOVINOS, 5, Piracicaba, 1993. Cana-de-açúcar e seus subprodutos para bovinos. Piracicaba:FEALQ, 1993. p.107-126.

BRODERICK, G. A ; CLAYTON, M. K. A statistical of animal and nutrition factors influencing concentrations of milk urea nitrogen. Journal of Dairy Science, v.80, p. 2964-2971, 1997.

CARVALHO, L. C. C.; GRAÇA, L. R. Produtividade agrícola da cana-de-açúcar o Estado de São Paulo. Brasil Açucareiro, v. 58, n. 4, p. 36-59, 1976. 
CHANEY, A.L.; MARBACH, E P. Modified reagents for determination of urea and amonia. Clinical Chemistry, v.8, p.130-37, 1962.

$\mathrm{CHURCH}, \mathrm{D}$. C. The ruminant animal: Digestive physiology and nutrition. Englewood Cliffs:Simon \& Schuster, 1988. 543p.

COX, D. R. Planning of experiments. New York:John Wiley, 1958. cap.10, p. 205-218: More about latin squares.

DAVIDOVICH, A .D.; BARTLEY.E. E.;CHAPMAN, R. M.; BECHTLE, A. et al. Ammonia toxicity in cattle. II. Changes in carotid and jugular blood components associated with toxicity. Journal of Animal Science, v.44, n.4, p.702-709,1977.

ERDMAN, R. A . Dietary buffering requirements of the lactating dairy cows: $A$ review. Journal of Dairy Science, v.71, p. 3246-3266, 1988.

ERWIN, W. S.; MARCO, G. J.; EMERY, E. M. Volatile fatty acid analyses of blood and rumen fluid by gas chromatography. Journal of Dairy Science, $v$. 44, p. 1768-1771, 1961.

FARIA, V. P. de O uso da cana-de-açúcar para bovinos no Brasil. In: SIMPÓSIO SOBRE NUTRIÇĀO DE BOVINOS, 5, Piracicaba, 1993. Canade-açúcar e seus subprodutos para bovinos. Piracicaba:FEALQ, 1993. p.1-16.

FERREIRO, H. M.; PRESTON, T. R.; SUTHERLAND, T. M. Investigation of dietary limitations on sugsr cane based diets. Tropical Animal Production, v. 2, p. 56-61, 1977. 
GOERING, N. K.; VAN SOEST, P. J. Forage fiber analysis: appartus, reagents, procedure and some applications.Washington:USDA, 1970, 20p.

HUBER, J. T. 1984. Uréia ao nível de rúmen. In: SIMPÓSIO SOBRE NUTRIÇĀO DE BOVINOS, 2, Piracicaba, 1984. Uréia para ruminantes. Piracicaba:FEALQ, 1984, p.7-24.

HUNTER, R. A .; SIEBER, B. D. The effect of supplements of rumen degradable protein and formoldehyde treated casein on the intake of low nitrogen roughages by Bos taurus and Bos indicus steers at different stages of maturity. Australian Journal of Agricultural Research, v.38, n.1, p. 209$218,1987$.

LENG, R. A.; PRESTON, T. R. Sugar cane for cattle production: Present constraints, perspectives and research priorities.Tropical Animal Production, v. 1, p. 194-201, 1976.

LENG, R. A. Limitações metabólicas de la cana de azúcar y sus derivados para el crescimento e producción de leche en ruminantes: Sistemas intensivos para producción animal y energia renovable con recursos tropicales. Colombia, 1988.

LOSADA, H; ARANANDA, E.; RUIZ, J.; ALDEETE, R. Effect of urea on voluntary intake and metabolic parametrs in bull fed sugar cane and molasses. Tropical Animal production, v. 4, n.2, p.168-171, 1979.

LUDOVICO,A ; MATTOS, W. R.S. Avaliação de dieta à base de cana-deaçúcar e diferente niveis de semente de algodão. Revista da Sociedade Brasileira de Zootecnia, v. 26, n.2, p. 403-410, 1997. 
MANZANO, A ; MATTOS, W. R. S.; LIMA, U. de A . Cana-de-açúcar na alimentação de bovinos leiteiros. II. Influência dos teores de farelo de soja nos valores de $\mathrm{pH}$, ácidos graxos voláteis, amônia e número de protozoários do conteúdo ruminal. XX REUNIÃO ANUAL DA SOCIEDADE BRASILEIRA DE ZOOTECNIA, Pelotas, 1983. Anais. Pelotas:SBZ, 1983. p.91-92.

MATOS, N. J. M. Niveis de ingestão de alimentos e de uréia sobre alguns parâmetros ruminais e digestão total e parcial em bovinos, alimentados com dieta à base de cana-de-açúcar e uréia suplementada com farelo de arroz. Viçosa, 1990. 119p. Tese (Doutorado) Universidade Federal de Viçosa, MG.

MATSUOKA, S. The contribution of man-made varieties to the sugarcane industry in São Paulo. Ciência e Cultura, v. 43, n. 4, p. 282-289, 1991.

MATSUOKA, S; HOFFMANN, H. P. Variedades de cana-de-açúcar para bovinos. In: SIMPÓSIO SOBRE NUTRIÇÃO DE BOVINOS, 5, Piracicaba, 1993. Cana-de-açúcar e seus subprodutos para bovinos. Piracicaba:FEALQ, 1993. p.17-35.

MEHREZ, A . Z.; ORSKOV, E. R.; McDONALD, I. Rates of rumen fermentation in relation to ammnia concentration. Brithish Journal of Nutrition, v.38, n.3, p.437-443, 1977.

MINOR, S.; MACLEOD, N. A ; PRESTON, T. R.; LENG, R.A. Studies on digestion in diferent sections of the intestinal tract of bulls fed sugar cane/urea with different supplements. Tropical Animal production, v. 2, n.2, p.63-174, 1977. 
MIRANDA, L. F.; QUEIROZ, A . C. de; VALADARES, S. C.; CECON, P.R. et al. Efeito da proteína dietética na concentração de uréia plasmática de novilhas. In: XXXV REUNIÃO DA SBZ, Botucatu, 1998. Anais. Botucatu: SBZ, 1998. p.71-73.

MONTPELLIER, F. A .; PRESTON, T.R. Digestibility and voluntary intake on sugar cane diets: effects of the chopping the cane stalk in particles of different sizes. Tropical Animal Production, v. 2, p.40-43,1977.

MOORE, D. A .; VARGA, G. Bun and Mun: Urea nitrogen in dairy cattle. The Compendium of Continuous Education, v.18,n.6, p.712-720,1996.

MOREIRA, H.A.; MELLO, R.P. Cana-de-açúcar + uréia: novas perspectivas para alimentação de bovinos na época da seca. Coronel Pacheco: EMBRAPA, CNPGL, 1986. (EMBRAPA. CNPGL. Circular Técnica, 29).

NOCEK, J.E.; HART, S.P.; POLAN, E. Rumem ammonia concentration as influenced by storage time, freezing and thawing, acid preservative, and methods of ammonia determination. Journal of Dairy Science, v.70, p.601607, 1987.

NUNES Jr, D. Variedades de cana: perspectivas de substituição e expectativa de ganhos de produtividade. STAB, v. 6, n. 2, p. 9-13, 1992.

NUTRITION RESEARCH COUNCIL. Nutrient Requirement of dairy cattle, 6 ed., Washington, National Academy of Science,1988 
OWENS, F. N; GOETSCH, A . L. Ruminal fermentation. In: $\mathrm{CHURCH,} \mathrm{D.} \mathrm{C.} \mathrm{The}$ ruminant animal: Digestive physiology and nutrition. Englewood Cliffs:Simon \& Schuster, 1988. cap.8, p.145-171.

OWENS, F. N.; ZINN, R. Protein metabolism of ruminant animals. In: $\mathrm{CHURCH}$, D. C. The ruminant animal: Digestive physiology and nutrition. Englewood Cliffs:Simon \& Schuster, 1988. cap.12, p.227-249.

PATE, F. M. Nutritive value of sugar cane at different stages of maturity. Tropical Animal Production, v. 2, n. 1, p. 108 (abstracts), 1977.

PRESTON, T. R.; LENG, R. A. Utilization of tropical feeds by ruminants. In: RUCKEBUSCH \& THIVEND. Digestive Phisiology and metabolism in ruminants. 1. Connecticut: Ed. AVI Publishnig Company, Inc., 1981, cap.30, p. 621-640.

PRESTON, T. R. Better utilization of crops residues and byproducts in animal feeding: research guidelines - 2. A pratical manual for research works. In: FAO Animal Production and Health Paper, 50/2, FAO, 1986.

RAVELO,G.; LENG, R.A. Pattern of rumen fermentation on diets based on chopped sugar cane with or without urea. Tropical Animal Production, v. 1, p. 194-201, 1976. /Resumo 23 em Sugar cane for cattle production: Present constraints, perspectives and research priorities.

RODRIGUES, F. M. Niveis de uréia na dieta básica de cana-de-açúcar para novilhas leiteiras em confimanento. Belo Horizonte, 1985. 59p. Dissertação (Mestrado) - Faculdade de Medicina Veterinária, Universidade Federal de Minas Gerais. 
RODRIGUES, $A$. de $A$. Efeito da suplementação com nitrogênio e enxofre no consumo e ganho de peso por novilhas alimentadas com cana-de-açúcar. ARS Veterinária, v.8, n.2, p. 148-155, 1992.

RODRIGUEZ, N.M.; FIGUEIRA, D. G.; AROEIRA, L.J. M.; TORRES, M. P. LOPES, F. C. F. Efeito do nível de uréia sobre a digestibilidade aparente e o balanço de nitrogênio em bovinos leiteiros alimentados com cana-de-açúcar. Arquivo Brasileiro de Medicina Veterinária e Zootecnia, v.45, n.1, p. 5970, 1993.

RUSSEL, J. B.; HESPELL, R. B. Microbial rumen fermentation. Journal of Dairy Science, v. 64, p. 1153-1169, 1981.

SAS INSTITUTE. User's guide: statistics: 1988

SATTER, L. D.; SLYTER, L . L. Effect of amonia concentration on rumen microbial production in vitro. Britanic Journal Nutrition, v. 32, p. 199-208, 1974.

SATTER, L. D.; HOFFLER, Nitrogen requirement and utilization in dairy cattle. Journal of Dairy Science, v. 58, p.1219-1237, 1975.

SATTER, L. D. Protein supply from undergraded dietary protein. Symposium: Protein and fiber digestion, passage and utilization in lactating cows. Journal of Dairy Science, v. 69 , p. 2734-2749, 1986.

SHIRLEY, R. L. Nonprotein nitrogen utilization.. In: SHIRLEY, R. L. Nitrogen and energy nutrition of ruminants. Orlando: Academic Press, 1986. cap.7, p149-171. 
SILVA, S. C. Cana-de-açúcar como alimento volumoso suplementar. In: Peixoto, A. M.; Moura, J. C. e Faria, V. P. (Ed.). Volumosos para bovinos. Piracicaba: FEALQ, 1993, 177p.

SLYTER, L. L. Ability of ph - selected mixed ruminal microbial populations to digest fiber at various pHs. Appied Enviroment of Microbiology, v.52, n. 2, p. $390-391,1986$

SNIFFEN, C. J.; ROBINSON, P.H. Microbial growth and flow as influenced by dietary manipulations. Journal of Dairy Science, v. 70, p. 425-437, 1987.

SONG, M. K.; KENNELLY, J. J. Ruminal fermentation pattern, bacterial population and ruminal degradation of fed ingredients as influenced by ruminal ammonia concentration. Journal of Animal Science, v.68, p. 1110$1120,1990$.

SWENSON, M. J.; REECE, W. O . Dukes Fisiologia dos Animais Domésticos, Rio de Janeiro:Guanabara Koogan,1996. 856p.

TALKE, H.; SCHUBERT, G. E. Kliniche Wochenschrift, v.43, n.174, 1965.

VALDEZ, R. E.; ALVAREZ, F. J.; FERREIRO, H. M.; GUERRA, F. et al. Rumen function in cattle given sugar cane. Tropical Animal Production, v. 2, p. 260-272, 1977.

VAN SOEST, P. J. Nutritional ecology of the ruminant. 2.ed. Ithaca:Comstock Publ., 1994. cap.21, p.337-353: Intake. 
VALVASORI, E., LAVEZZO,W., LUCCI, C. de S.; MELOTTI, L. et al. Alterações na fermentação ruminal de bovinos alimentados com cana-de-açúcar em substituição à silagem de milho. In: XXXV REUNIĀO DA SBZ, Botucatu, 1998. Anais. Botucatu: SBZ, 1998.p.86-88.

WILSON, G.; MARTZ, F. A .; CAMPBELL, J. R.; BECHER, B. A . Evalution of factors responsible for reduced voluntary intake of urea diets for ruminants. Journal of Animal Science, v.41, p. 1431-1437,1990.

WOHLT, J. E.; CLARK, J. H.; BLAISDELL, F. S. Nutritional value of urea versus preformed protein for ruminants. II. Nitrogen utilization by dairy cows fed corn based diets containing supplemental nitrogen from urea and/or soybean meal, Journal of Dairy Science, v.61, p.916-931, 1978. 